\title{
Results of Monitoring Water Levels in the Wetlands of Fourmile Branch near the F and H Areas of SRS: January to December 2002 (U)
}

N. V. Halverson

Savannah River Technology Center

July 2003

Westinghouse Savannah River Company Savannah River Site

Aiken, SC 29802

Prepared for the U.S. Department of Energy Under

Contract Number DE-AC09-96SR18500

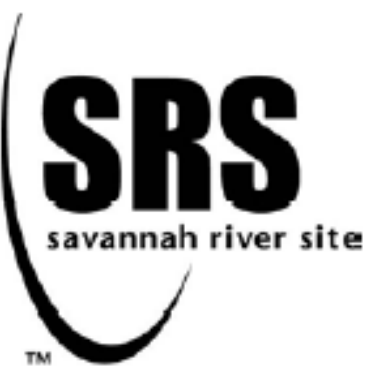


This document was prepared in conjunction with work accomplished under Contract No. DE-AC09-96SR18500 with the U. S. Department of Energy.

\section{DISCLAIMER}

This report was prepared as an account of work sponsored by an agency of the United States Government. Neither the United States Government nor any agency thereof, nor any of their employees, makes any warranty, express or implied, or assumes any legal liability or responsibility for the accuracy, completeness, or usefulness of any information, apparatus, product or process disclosed, or represents that its use would not infringe privately owned rights. Reference herein to any specific commercial product, process or service by trade name, trademark, manufacturer, or otherwise does not necessarily constitute or imply its endorsement, recommendation, or favoring by the United States Government or any agency thereof. The views and opinions of authors expressed herein do not necessarily state or reflect those of the United States Government or any agency thereof.

This report has been reproduced directly from the best available copy.

Available for sale to the public, in paper, from: U.S. Department of Commerce, National Technical Information Service, 5285 Port Royal Road, Springfield, VA 22161, phone: (800) 553-6847, fax: (703) 605-6900

email: orders@ntis.fedworld.gov

online ordering: http://www.ntis.gov/help/index.asp

Available electronically at http://www.osti.gov/bridge

Available for a processing fee to U.S. Department of Energy and its contractors, in paper, from: U.S. Department of Energy, Office of Scientific and Technical Information, P.O. Box 62, Oak Ridge, TN 37831-0062,

phone: (865)576-8401,

fax: (865)576-5728

email: $\underline{\text { reports@ adonis.osti.gov }}$ 


\section{Results of Monitoring Water Levels in the Wetlands of Fourmile Branch near the F and H Areas of SRS: January to December 2002}

\section{Executive Summary}

Since 1996, a network of piezometers has been used to measure hydraulic head in the water-table aquifer (Upper Aquifer Zone of the Upper Three Runs Aquifer, or UAZ of the UTRA) along the groundwater outcrops (i.e. seeplines) near the F- and H-Areas. The piezometers were installed near the seeplines to assess potential impacts of the F- and H-Area Groundwater Remediation Wastewater Treatment Units (WTUs) on the riparian wetlands located between the former F- and H-Area seepage basins and Fourmile Branch. The piezometers were installed in areas expected to be most impacted by the remediation system. Eight additional piezometers were added to the network in 2002 in two locations near the F-Area seepline and two locations near the H-Area seepline, extending coverage further downstream from the seepage basins.

The goals of the RCRA Part B Permit governing the WTUs are to 1) achieve a 70\% reduction in the mass flux of tritium to Fourmile Branch within five years of Corrective Action Plan approval and reduce the discharge of other contaminants (metals and radionuclides other than tritium) to Fourmile Branch to levels less than the Groundwater Protection Standards (GWPS), and 2) reduce the discharge at the seepline of all contaminants to levels that are less than the GWPS by July 31, 2010. Because of the potential for WTU operation to dry portions of the nearby wetland areas, the purpose of the piezometer network was: 1) to establish baseline hydraulic head data for the water-table aquifer (UAZ) at the F- and $\mathrm{H}$-Area seeplines prior to startup of the groundwater extraction/injection remediation system (completed), and 2) to observe the effects of the remediation system on the hydraulic head after system start-up (ongoing).

Hydraulic head was measured monthly in 2002 using an electric water-level meter at each of the piezometers. For the piezometers equipped with data loggers, hydraulic head was recorded hourly in addition to the monthly measurements. Results from 2002 were compared with previous years' results, including results recorded before the WTUs began operating (the baseline period).

Minimum and average measurements at nearly all the F- and H-Area piezometers were lower in 2002 than in 2001 and the baseline period. Two of the three reference piezometers exhibited large drops in average hydraulic head compared to 2001, and all three had average heads lower than the baseline period. The average change in elevation for each area was $0.8 \mathrm{ft}, 0.7 \mathrm{ft}$, and $2.1 \mathrm{ft}$ for F-Area, H-Area, and the reference piezometers, respectively. The magnitude of the decrease at the reference locations reflects the ongoing drought in 2002.

Drought conditions continued for much of 2002. Drought status in counties that comprise SRS was upgraded from severe to extreme in July, then downgraded to incipient drought status in November. Fand H-Area rainfall in 2002 was lower than the long-term (1985-2000) average, but was higher than in 2000 and 2001 due to higher than average rainfall received in November and December. Rainfall averaged 3.6 inches per month at F Area and 3.7 inches per month at H Area in 2002. The average monthly rainfall calculated for the baseline period was 3.9 inches per month for both F Area and H Area. 
Decreases in groundwater extraction volumes tempered the effect of drought in the F- and H-Area piezometers. Daily groundwater extraction volumes dropped by an average of $45 \%$ in F Area in June, and again from August through December, and by about 50\% in $\mathrm{H}$ Area in December. Hydraulic head elevations began increasing in August in the F-Area piezometers. This timing coincided more closely to the prolonged reduction in groundwater extraction than to an increase in rainfall, which began in June or July. Hydraulic head in FPZ004A, which is located close to the extraction wells, increased by nearly three feet during the latter half of the year following reduction in extraction rates. The greatest decreases in average hydraulic head in $\mathrm{H}$ Area continued to be in the piezometers closest to the extraction wells. However, hydraulic heads in these $\mathrm{H}$-Area piezometers rose in December as a result of reduction in $\mathrm{H}$ Area groundwater extraction volumes.

Wetlands are defined by the presence of hydric soils, saturated soil conditions during a portion of the growing season, and vegetation adapted to live in saturated soils. Lowering groundwater levels for a prolonged period could change the wetland hydrologic conditions and the vegetation growing in these areas. In many locations, the hydraulic head never reached the root zone during 2002. For several years now, the water table has remained below levels required to sustain the herbaceous components of wetland vegetation at some locations. These hydrologic conditions may allow early successional species to germinate in these areas. In other areas, changes already have occurred. Nelson (2001) documented changes in herbaceous species diversity and establishment of early successional non-wetland species due to declines in water levels in recent years in the F- and H-Area tree kill zones (FPZ005A and HPZ001A are located there), areas where tree mortality in seepline-fed wetlands downslope from the seepage basins was first identified in the 1970s. However, these changes would not cause the areas to lose their wetland classification. 


\section{TABLE OF CONTENTS}

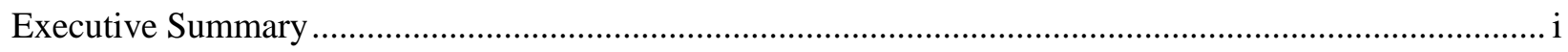

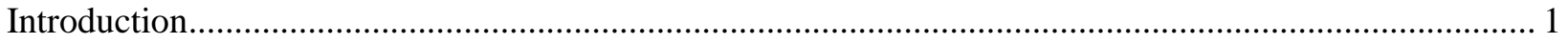

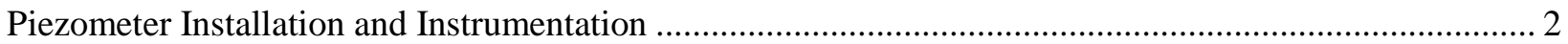

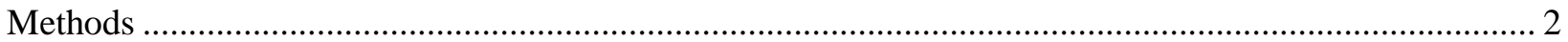

Status of the Wastewater Treatment Units........................................................................................... 2

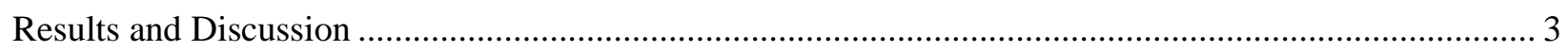

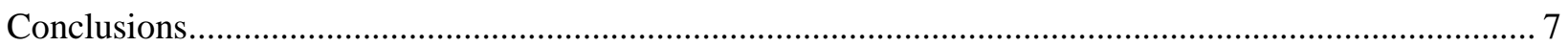

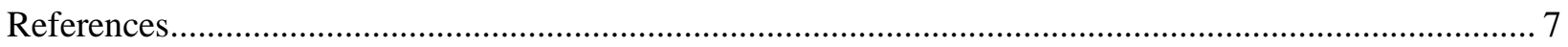

\section{LIST OF TABLES}

Table 1 Piezometer Construction Information

Table 2 Groundwater extraction (thousands of gallons) by the F-Area Groundwater Remediation Wastewater Treatment Unit, 1997 to 2002.

Table 3 Groundwater extraction (thousands of gallons) by the H-Area Groundwater Remediation

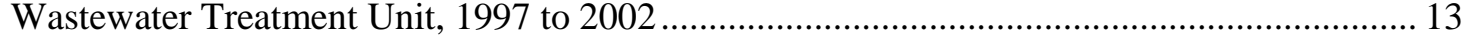

Table 4 Monthly water levels (feet, msl) at individual piezometers, January to December 2002 ......... 14

Table 5 Maximum, minimum and average water level measurements, January to December $2002 \ldots . .15$

Table 6 Comparison of piezometer water-level statistics in 2001 and 2002 ...................................... 16

Table 7 Comparison of the 2002 piezometer water-level statistics with baseline values ...................... 17

Table 8 Population Correlation Coefficients for Monthly Hydraulic Head vs. Groundwater Extraction, Temperature, Rainfall, and Cumulative Rainfall Surplus/Deficit ......................... 18

Table 9 Population Correlation Coefficients between Groundwater Extraction, Rainfall, and Cumulative Rainfall Surplus/Deficit

\section{LIST OF FIGURES}

Figure 1 Extraction / injection well and piezometer locations for the water table aquifer (UAZ) in F Area......

Figure 2 Extraction / injection well and piezometer locations for the water table aquifer (UAZ) in $\mathrm{H}$

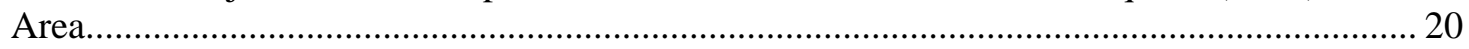

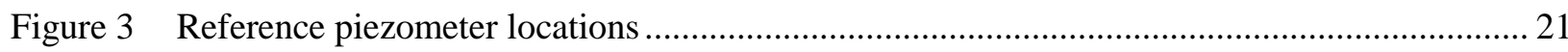

Figure 4 Groundwater extraction rates (gal/day) in F Area and H Area, 2002 .................................. 22

Figure 5 Monthly and cumulative rainfall (inches) in F Area, 1996 to 2002 ...................................... 23

Figure 6 Monthly and cumulative rainfall (inches) in H Area, 1996 to 2002 .................................... 24

Figure 7 Monthly hydraulic head elevations (ft, msl) at FSP249A and FSP249B, through December

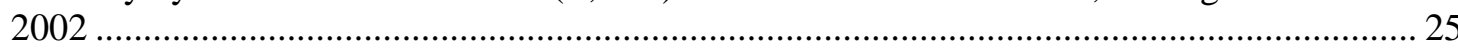

Figure 8 Monthly hydraulic head elevations (ft, msl) at FPZ001A, January 1996 to December 2002... 25

Figure 9 Monthly hydraulic head elevations (ft, msl) at FPZ002A, January 1996 to December 2002... 26

Figure 10 Monthly hydraulic head elevations (ft, msl) at FPZ003A, January 1996 to December 2002... 27

Figure 11 Monthly hydraulic head elevations (ft, msl) at FSP002A and FSP002B through December

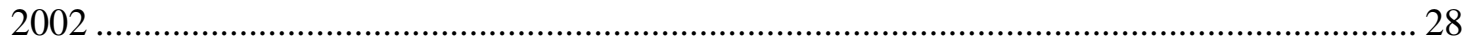

Figure 12 Monthly hydraulic head elevations (ft, msl) at FPZ004A, January 1996 to December 2002... 28 
Figure 13 Monthly hydraulic head elevations (ft, msl) at FPZ005A and FPZ005B, January 1996 to

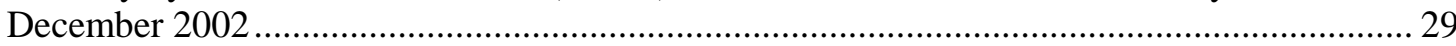

Figure 14 Monthly hydraulic head elevations (ft, msl) at FPZ006A and FPZ006B, January 1996 to

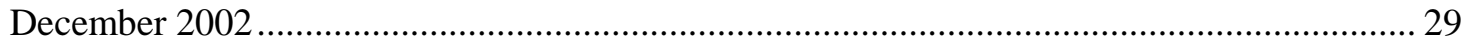

Figure 15 Monthly hydraulic head elevations (ft, msl) at FPZ007A and FPZ007B, January 1996 to

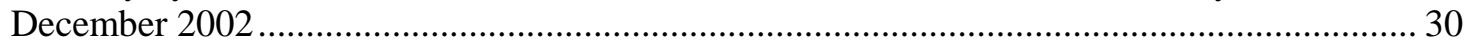

Figure 16 Monthly hydraulic head elevations (ft, msl) at FPZ008A and FPZ008B, January 1996 to December 2002.

Figure 17 Monthly hydraulic head elevations (ft, msl) at HSP076A \& HSP076B, through

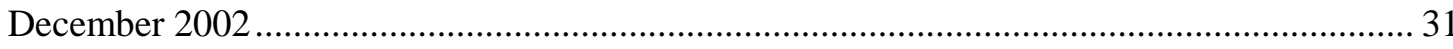

Figure 18 Monthly hydraulic head elevations (ft, msl) at HSP060A and HSP060B, through

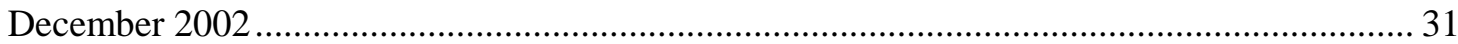

Figure 19 Monthly hydraulic head elevations (ft, msl) at HPZ001A, January 1996 to December 2002 .. 32 Figure 20 Monthly hydraulic head elevations (ft, msl) at HPZ002A, January 1996 to December 2002 .. 32

Figure 21 Monthly hydraulic head elevations (ft, msl) at HPZ003A and HPZ003B, January 1996 to

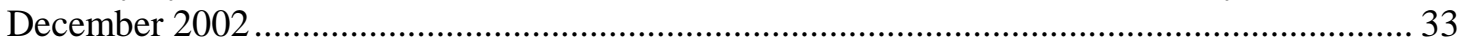

Figure 22 Monthly hydraulic head elevations (ft, msl) at HPZ004A, January 1996 to December 2002 .. 33

Figure 23 Monthly hydraulic head elevations at HPZ005A and HPZ005B (ft, msl), January 1996 to December 2002. 34

Figure 24 Monthly hydraulic head elevations (ft, msl) at HPZ006A, January 1996 to December 2002 .. 35 Figure 25 Monthly hydraulic head elevations (ft, msl) at FHR001, July 1997 to December 2002 .......... 35 Figure 26 Monthly hydraulic head elevations (ft, msl) at FHR002, July 1997 to December 2002 .......... 36 Figure 27 Monthly hydraulic head elevations (ft, msl) at FHR003, July 1997 to December 2002 .......... 37 Figure 28 Comparison of hydraulic head elevation and rainfall at FPZ001A (F Area) in 2002 2............. 37 Figure 29 Comparison of hydraulic head elevation and rainfall at FPZ002A (F Area) in 2002 2............. 38 Figure 30 Comparison of hydraulic head elevation and rainfall at FPZ003A (F Area) in 2002 .............. 38 Figure 31 Comparison of hydraulic head elevation and rainfall at FPZ004A (F Area) in 2002 .............. 39 Figure 32 Comparison of hydraulic head elevation and rainfall at FPZ005A (F Area) in 2002 .............. 39 Figure 33 Comparison of hydraulic head elevation and rainfall at FPZ006A (F Area) in 2002 .............. 40 Figure 34 Comparison of hydraulic head elevation and rainfall at FPZ007A (F Area) in 2002 .............. 40 Figure 35 Comparison of hydraulic head elevation and rainfall at FPZ008A (F Area) in 2002 ............. 41 Figure 36 Comparison of hydraulic head elevation and rainfall at HPZ001A (H Area) in 2002 ............ 41 Figure 37 Comparison of hydraulic head elevation and rainfall at HPZ002A (H Area) in 2002 ............ 42 Figure 38 Comparison of hydraulic head elevation and rainfall at HPZ003A (H Area) in 2002 ............ 42 Figure 39 Comparison of hydraulic head elevation and rainfall at HPZ004A (H Area) in 2002 ............ 43 Figure 40 Comparison of hydraulic head elevation and rainfall at HPZ005A (H Area) in 2002 ............ 43 Figure 41 Comparison of hydraulic head elevation and rainfall at HPZ006A (H Area) in 2002 ............ 44 Figure 42 Comparison of hydraulic head elevation and rainfall (H Area) at FHR001 in 2002 ............... 44 Figure 43 Comparison of hydraulic head elevation and rainfall (H Area) at FHR002 in 2002 ...............45 Figure 44 Comparison of hydraulic head elevation and rainfall (H Area) at FHR003 in 2002 ............... 45

Figure 45 Changes from the baseline period for annual average hydraulic head elevations compared with groundwater extraction

Figure 46 F-Area WTU extraction volume compared to FPZ004A hydraulic head elevations

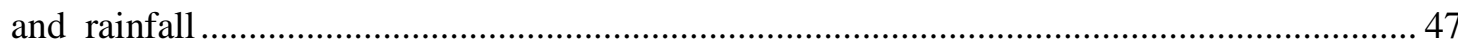

Figure 47 H-Area WTU extraction volume compared to HPZ002A and HPZ005A hydraulic head elevations and rainfall 48 


\section{Introduction}

Seepage basins in the $\mathrm{F}$ and $\mathrm{H}$ Areas of the Savannah River Site (SRS) formerly received low-level radioactive wastewater from the nuclear materials separations facilities. This wastewater consisted mostly of sodium hydroxide, nitric acid, low levels of various radionuclides (primarily tritium) and some metals (Killian et al. 1985a,b). Discharges to the seepage basins were discontinued in 1988 and the basins were closed in accordance with an approved Resource Conservation and Recovery Act (RCRA) closure plan by February 1991.

The aquifer beneath and down-gradient of the basins was contaminated as a result of basin operations. The contamination is located primarily in the Upper Aquifer Zone (UAZ) (i.e. the water-table aquifer) of the Upper Three Runs Aquifer (UTRA) and in the Lower Aquifer Zone (LAZ) of the UTRA. Near the seepage basins in both $\mathrm{F}$ and $\mathrm{H}$ Areas, shallow groundwater flows toward Fourmile Branch. The UAZ discharges to the wetlands and Fourmile Branch, whereas the LAZ discharges primarily to Fourmile Branch. Contaminants originating from the seepage basins have been detected in shallow groundwater outcrops (i.e. the seepline) in the wetlands along Fourmile Branch near both $\mathrm{F}$ and H Areas (Haselow et al. 1990, Dixon et al. 1993, Dixon and Rogers 1993, Dixon et al. 1994).

Groundwater remediation wastewater treatment units (WTUs) were installed near F and $\mathrm{H}$ Areas in accordance with a RCRA Hazardous Waste Part B Permit to clean up the groundwater. The goals of the RCRA Part B Permit are to 1) achieve a $70 \%$ reduction in the mass flux of tritium to Fourmile Branch within five years of Corrective Action Plan approval and reduce the discharge of other contaminants (metals and radionuclides other than tritium) to Fourmile Branch to levels less than the Groundwater Protection Standards (GWPS), and 2) reduce the discharge at the seepline of all contaminants to levels that are less than the GWPS by July 31, 2010.

The WTUs include a network of extraction and injection wells. Figures 1 and 2 show the locations of the wetlands near Fourmile Branch and the extraction wells for the water-table aquifer (the UAZ of the UTRA) in F Area and $\mathrm{H}$ Area, respectively. The extraction well numbers have the prefix "FEX" or "HEX."

Models simulating the operation of the WTUs predicted decreases in the water level of up to six feet at the seepline and in the wetlands nearby (Sadler 1995, Flach 1998). Decreases in water levels could result in drying of a portion of the wetlands, and an overall movement of the seepline towards Fourmile Branch. Chronic depression of the water table at portions of the wetlands affected by the extraction wells could alter the wetland plant and animal communities in this area.

Changes in water levels in and near the wetlands along Fourmile Branch needed to be monitored to assess the impacts of the F- and H-Area WTU remediation systems on the wetlands. The definition of wetlands differs between federal agencies. Under the U.S. Environmental Protection Agency (EPA) and the U.S. Corps of Engineers (USCOE) definition, an area must exhibit three attributes - hydric soil, hydrophytic vegetation and wetland hydrology - to be considered a wetland. An area is considered to have wetland hydrology if it is inundated or saturated to the surface continuously for at least $5 \%$ of the growing season in most years. For soil saturation to impact vegetation, it must occur within a major portion of the root zone (usually within 12 inches of the surface) (USCOE 1987).

To accomplish this monitoring, a network of piezometers was established in 1996 in and near the wetlands of Fourmile Branch in both $\mathrm{F}$ and $\mathrm{H}$ Areas (Dixon 1996). The purpose of the piezometer network was two-fold: 1) to establish baseline hydraulic head data for the water-table aquifer (the UAZ of the UTRA) at the F- and HArea seeplines prior to startup of the groundwater extraction/injection remediation system (the baseline period), and 2) to observe the effects of the remediation system on the water table levels after system start-up. The first objective, developing a baseline, was completed in 1997. The second objective is ongoing. The purpose of this report is to present the results of the monthly and continuous hydraulic head elevations measured in 2002 at these piezometers. 


\section{Piezometer Installation and Instrumentation}

In 1996 and 1997, 23 water-table piezometers were installed at 17 locations in and near the wetlands of Fourmile Branch near $\mathrm{F}$ and $\mathrm{H}$ Areas and in an upstream location. These piezometers were given the prefixes "FPZ", "HPZ," and "FHR" respectively. The FPZ (Figure 1) and HPZ (Figure 2) piezometers were installed near the seepline, focusing on those areas expected to be most impacted by the remediation system. The location of the seepline varies with time depending on the elevation of the water table. At locations with heterogeneous stratigraphy, piezometers were installed in clusters so that the hydraulic head could be measured for each layer. The deeper piezometers were given well numbers with the suffix "A" and the shallower piezometers, the suffix "B." The FHR piezometers (Figure 3) were installed in an upstream reference area located in the wetlands of Fourmile Branch, but outside the expected area of influence of the remediation system. Hydraulic head changes observed in these reference piezometers could be compared to changes observed in the FPZ and HPZ piezometers to help distinguish between natural variation in hydraulic head and treatment system impacts.

In 2002, additional piezometers were installed in two locations near the F-Area seepline (given the "FSP" prefix, Figure 1) and two locations near the H-Area seepline (given the "HSP" prefix, Figure 2). The piezometers were installed in clusters so that the hydraulic head could be measured for each layer. The letter following the piezometer number indicates the relative depth, with "A" corresponding to the deeper layer and "B" corresponding to the shallower layer.

With the exception of FPZ003A, all FPZ, HPZ and FHR piezometers were installed using hand augering equipment (3 $1 / 4$ " bucket auger) in accordance with WSRC-3Q5 (Chapter 7) procedures. Installation methods are summarized in Table 1 and described in Dixon (1996). Piezometer FPZ003A, and the FSP and HSP piezometers were installed using a hollow stem augering method. Additional piezometer construction information can be found in Halverson (2000).

To investigate the natural water level variability and storm event influences in the Fourmile Branch riparian wetland system, nine piezometers were equipped with data logging equipment in 1996 to allow continuous water level monitoring. Five additional piezometers were equipped with data loggers in 1998. The three reference piezometers were equipped with data loggers in 1999.

\section{Methods}

Water levels in the piezometers were measured monthly in 2002 using a manual electric waterlevel meter. From these measurements, the hydraulic head was determined for each location.

Water levels were measured and recorded hourly at the piezometers equipped with data loggers. The data loggers were In-Situ Inc. TROLL Model SP4000 units with 15 psig pressure transducers. An unusually long cold spell during the winter of 2002/2003 shortened the life of the data logger batteries. Battery levels in the data logger at piezometer FHR003 dropped too low to sustain logger operation, and data recorded since the previous downloading were lost.

Some of these piezometers were utilized in other studies during 2002. In cases where water sample collection or other work in the piezometers temporarily disturbed the water levels, the affected data were deleted.

\section{Status of the Wastewater Treatment Units}

The monthly volumes of groundwater treated by the F-Area and H-Area WTUs (1997-2002) are shown in Tables 2 and 3, respectively. Daily extraction (i.e. pumping) rates for 2002 are shown in Figure 4.

The F-Area Groundwater Remediation WTU began operating in shakedown mode in April 1997, and continued to operate in this manner during the remainder of 1997 and all of 1998. 
Flow rates were limited due to system testing, and full-operation was not initiated. Pumping rates were not consistent due to significant system downtime (WSRC 1997a, 1998a\&c, 1999a). In 1999, the F-Area WTU operated $57 \%$ of the time. By 2000 , the F-Area WTU was operating essentially full time.

In 2002, the F-Area WTU operated at essentially full capacity from January through May, and again in July. In June and from August to December, however, pumping rates averaged just $55 \%$ of the rates from the beginning of the year (Long 2002b, 2003a) (Table 2).

The H-Area WTU began operating in a shakedown mode in July 1997 and continued in this mode in 1998. Flow rates were limited due to system testing and limited injection well capacity, and there was significant system downtime (WSRC 1997b, 1998b\&d, 1999b). In 1999 , the H-Area WTU operated $82 \%$ of the time. By 2000, the H-Area WTU was operating essentially full time.

In 2002, the H-Area WTU operated at essentially full capacity from January through November. In December, however, the pumping volume dropped to about $50 \%$ of the average monthly volume (Long 2002b, 2003a) (Table 3).

\section{Results and Discussion}

Drought conditions continued for much of 2002. In July, drought status in counties that comprise SRS was upgraded from severe to extreme, the most serious drought category (SCDNR 2002a). However, in November these counties were downgraded to incipient drought status, the least severe classification (SCDNR 2002b).

F- and H-Area rainfall in 2002 was lower than the long-term (1985-2000) average, but was higher than in 2000 and 2001 due to higher than average rainfall received in November and December. For the most of the year, cumulative rainfall was lower in 2002 than in other years of this study (1996-2001). However, more than four inches of rainfall per month in November and December for F Area and October through December in H-Area brought 2002 rainfall totals above 2000 and 2001 totals. In contrast, less than one inch of rain per month fell during the last quarter of 2001. Rainfall totals for 2002 were 42.9 inches (averaging 3.6 inches per month) measured at F Area and 44.9 inches (averaging 3.7 inches per month) measured at $\mathrm{H}$ Area. The average monthly rainfall calculated for the baseline period was 3.9 inches per month for both $\mathrm{F}$ Area and $\mathrm{H}$ Area. The long-term (1985 - 2000) average annual rainfall is 49 inches in $\mathrm{F}$ Area and 51 inches in $\mathrm{H}$ Area. Monthly and cumulative rainfall amounts for 1996 through 2002 and the long-term average are shown in Figures 5and 6 for $\mathrm{F}$ Area and $\mathrm{H}$ Area, respectively. The 2002 total rainfall in $\mathrm{F}$ Area was $8 \%$ higher than the 2001 total rainfall and $13 \%$ lower than the long-term average. $\mathrm{H}$ Area rainfall was $21 \%$ higher than the 2001 total rainfall and $13 \%$ lower than the long-term average.

Rainfall measured in $\mathrm{H}$ Area was used for comparison with reference piezometer hydraulic head because it is the closest meteorological station. Actual rainfall near the reference piezometers might have been significantly different than the rainfall measured at the $\mathrm{H}$ Area meteorological station, which recorded the most rainfall at SRS in 2002. Rainfall measured in 2002 at twelve different locations at SRS varied from about 34 inches near $\mathrm{P}$ Area to about 45 inches measured near H-Area.

Results from the monthly hydraulic head measurements for 2002 are presented in Table 4. Summary statistics for each location are presented in Table 5. Table 5 also presents summary statistics based on data logger measurements for 2002.

Table 6 compares the hydraulic head measurements from 2002 with 2001 measurements for the " $\mathrm{A}$ " series (deeper wells) and reference piezometers. Minimum and average measurements at nearly all F-Area piezometers were lower in 2002 than in 2001. The only exception was FPZ008A, where average hydraulic head was unchanged. The average change in elevation across the piezometer network was a $0.8 \mathrm{ft}$ decrease from 2001 levels. The largest differences in average elevation for F-Area piezometers occurred in FPZ001A, FPZ002A and FPZ003A, with 
decreases of one or more feet from 2001. Hydraulic head at FPZ004A, which has exhibited large decreases in previous years, rebounded during the last half of the year when groundwater extraction rates were reduced to about $55 \%$ of normal, resulting in an overall decrease in average head elevation of only $0.3 \mathrm{ft}$.

For the H-Area piezometers, minimum and average hydraulic head measurements were lower in 2002 than in 2001 for all but one piezometer, HPZ006A, where the average head was unchanged (Table 6). HPZ002A had the largest decrease in average hydraulic head for the third consecutive year (1.5 ft). Water level elevation in the $\mathrm{H}$-Area piezometer network decreased an average of $0.7 \mathrm{ft}$ from 2001 levels.

Two of the three reference piezometers exhibited large drops in hydraulic head while the third increased slightly (Table 6). The average hydraulic head decreased at FHR001 and FHR002 by $2.7 \mathrm{ft}$ and $3.6 \mathrm{ft}$, respectively, while the level at FHR003 was unchanged. From 2001 to 2002, the average change in average hydraulic head elevations over all three reference piezometers was a $2.1 \mathrm{ft}$ decrease.

Table 7 compares the 2002 groundwater elevations with baseline elevations. For F- and $\mathrm{H}$-Area piezometers, the pre-operational period was used for the baseline (January 1996 through March 1997 for F Area and January 1996 through June 1997 for H Area) (WSRC 1997a, 1998c). For the reference piezometers, the first 6 months of data (July - December 1997) were used as a baseline. These baseline periods spanned less than two years. Thus, while the baseline data may be useful for comparison with current water levels, that data may not truly represent the long-term average water levels at these locations.

The 2002 minimum and average hydraulic head elevations were all lower than in the baseline period for the F-Area piezometers, though the average FPZ008A elevation was only $0.1 \mathrm{ft}$ lower (Table 7). The largest change in average elevation for F-Area piezometers occurred in FPZ002A and FPZ004A, with decreases of 6.2 feet and $7.0 \mathrm{ft}$, respectively, compared to baseline levels. The average change in elevation across the piezometer network was a $3.3 \mathrm{ft}$ decrease from baseline levels. All F-Area piezometers except FPZ008A exhibited an increase in standard deviation in 2002 compared to the baseline period. On the average, the standard deviation for F-Area piezometers in 2002 was six times the baseline level.

In 2002, minimum and average hydraulic head elevations were lower for most H-Area locations compared to the baseline period (Table 7). HPZ003A and HPZ006A were exceptions. However, these piezometers are located within the wetlands bordering Fourmile Branch and could have been influenced by seasonal stream flows and periodic beaver-dam building activity. On the average, hydraulic head elevations in 2002 were $2.2 \mathrm{ft}$ lower than the baseline. If HPZ003A and HPZ006A are not included, average change in hydraulic head elevation was a $3.4 \mathrm{ft}$ decrease compared to the baseline. The largest changes in average elevation occurred in HPZ002A and HPZ005A, with decreases of 6.3 $\mathrm{ft}$ and $5.1 \mathrm{ft}$, respectively, compared with baseline levels. The standard deviation was higher in 2002 than in the baseline period for most H-Area piezometers, averaging about three times the baseline level.

Elevations at all the reference piezometers in 2002 were lower than the baseline, with declines ranging from $0.3 \mathrm{ft}$ to $6.5 \mathrm{ft}$. (Table 7). FHR003 levels showed less variation from baseline levels than either FHR001 or FHR002. The greatest decrease from baseline occurred at FHR002. The average decrease in average hydraulic head elevations over all three reference piezometers was $3.8 \mathrm{ft}$ compared to baseline.

Hydrographs for each F- and H-Area piezometer location were created from the monthly measurements and are presented in Figures 7 through 24. Hydrographs for the reference locations are shown in Figures 25 through 27. Each hydrograph covers the entire monitoring period.

Hydrographs of the hydraulic head elevations, based on the data logger measurements, are shown in Figures 28 through 41 for the F- and $\mathrm{H}$-Area piezometers. Figures 42 through 44 show the hydrographs from the data loggers at 
the reference piezometers. Elevations for the years 1996 to 2002 are plotted together. For periods in 2002 when the data loggers were not operating or head elevations dropped below the data logger, monthly data are shown. Rainfall in 2002 is also plotted on each of these hydrographs for comparison with the 2002 elevation data.

Hydraulic head elevations began increasing in August in the F-Area piezometers (Figures 28 through 35 ). This timing coincides more closely to the prolonged reduction in groundwater extraction, which also began in August, than to the increase in rainfall, which began in June or July. F-Area A-series piezometers ended the year with higher hydraulic heads than at the beginning of the year. The greatest increase over the year occurred at FPZ003A (Figure 30), the piezometer with the greatest variability in elevation. FPZ004A (Figure 31), which is located close to the extraction wells, also increased by nearly three feet due to a dramatic rise in hydraulic head following reduction in extraction rates during the latter half of the year. Prior to this rise in head, however, water levels sank below the bottom of the piezometer. FPZ003A and FPZ008A had the highest yearend hydraulic head elevations recorded since the beginning of the study.

H-Area A-series piezometers (Figures 36 through 41) generally ended the year with similar or higher hydraulic head than at the beginning of the year, except for HPZ004A which was slightly lower at the end of the year. HPZ005A (Figure 40) hydraulic head elevation was more than $4 \mathrm{ft}$ higher at the end of the year, and HPZ002A (Figure 37) was nearly two feet higher. These are the H-Area piezometers closest to the extraction wells. Both exhibited sudden increases in head corresponding to midNovember rainfall and further increases in December, which coincide with reduction in extraction rates.

In contrast, two of the reference piezometers, FHR001 (Figure 42) and FHR002 (Figure 43), ended the year with hydraulic heads two to three feet lower than at the beginning of the year, in spite of the fact that total rainfall in 2002 (in $\mathrm{H}$ Area) was actually higher than in 2001. Without the influence of extraction wells, the reference locations did not experience the same rise in hydraulic head caused by the reduction in groundwater extraction. A small rise in hydraulic head occurred at the end of the year in conjunction with late-year rainfall increases (Figures 42 and 43), but it was not enough to overcome the effects of the drought conditions that predominated in 2002. The third reference piezometer, which has exhibited little variation in head over the years, ended the year with a hydraulic head less than one inch higher than at the beginning of the year.

Hydraulic head at FPZ002A (Figure 29), HPZ002A (Figure 37), and HPZ005A/B (Figures 23 and 40) has remained below the plant root zone since 1999. The water table has remained below the root zone for four years at FPZ004A (Figure 31) and FHR002 (Figure 26), but since this study began in 1996, hydraulic head at these locations reached the root zone only during 1998, an exceptionally wet year, and the frequency of saturated soil conditions prior to 1996 is not known.

Figure 45 shows the difference between the annual average hydraulic head and the baseline for the years 2001 and 2002 for the piezometers closest to the extraction wells and the two most variable reference piezometers. The annual volumes of groundwater extracted at the F-Area and H-Area WTUs are also shown. The effects of drought during 2002 are revealed by the large decreases in reference piezometer hydraulic head compared to 2001 (approximately $2.5 \mathrm{ft}$ to $3 \mathrm{ft}$ ). Decreases in H-Area groundwater extraction volume in December and the resulting rebound in hydraulic head tempered the effect of drought, as seen in HPZ002A and HPZ005A, which decreased by about $2 \mathrm{ft}$ compared to 2001. The more prolonged reduction in F-Area groundwater extraction volumes is reflected in smaller decreases in hydraulic head, $1 \mathrm{ft}$ to 1.5 $\mathrm{ft}$, from 2001 levels.

To further investigate the effect of the WTU operation on the hydraulic head at the seepline piezometers, the daily volume of groundwater extracted was plotted along with the hydrographs of piezometers that exhibited declining head levels. Effects were discernable 
at some piezometers, but because the increase in rainfall during the latter part of the year overlaps the periods with reduced extraction, the effect of WTU operation on the hydraulic head was not clear for other piezometers. The effect was most pronounced at FPZ004A, HPZ002A and HPZ005A. These are the three piezometers closest to extraction wells. In addition, the extraction wells closest to FPZ004A (FEX 1, FEX2, FEX3 and FEX4, see Figure 1 and Table 2) and HPZ002A (HEX1 and HEX17, see Figure 2 and Table 3) extracted more groundwater than the other extraction wells. The reduction in groundwater extraction during the last part of the year was more pronounced in these extraction wells, as well.

Figure 46 compares F-Area WTU groundwater extraction and hydraulic head at piezometer FPZ004A. The effect of the extraction on the hydraulic head could be seen clearly during three periods when the extraction decreased. During these times, the hydrographs showed steady increases in hydraulic head that look different from the shorter-lived, nearly instantaneous increases brought about by rainfall events. Hydraulic head rose from August through October, even during a 12-day rainless period in September. Individual rainfall events were not distinguishable from August through October, indicating the reduction in extraction levels had a greater effect than the increased rainfall. A similar rise in head could be seen to a lesser degree other F-Area piezometers, but individual rainfall events were still distinguishable.

Figure 47 shows the comparison between $\mathrm{H}-$ Area WTU groundwater extraction and hydraulic head at piezometer HPZ002A and HPZ005A. The hydraulic head response shows up clearly during December, when extraction volumes were greatly reduced. Onset of the increase in hydraulic head correlates precisely with the drop in extraction, not rainfall.

Linear correlation was used to identify the strength of relationships between hydraulic head trends and operational and rainfall trends. Monthly average hydraulic heads were calculated and compared with monthly values for groundwater extraction, total rainfall, and the rainfall deficit or surplus (calculated using monthly rainfall averaged from 1985-2000 data, and assumed to be zero at the beginning of the program in 1996). The population correlation calculation returns a coefficient ( $r$ ) equal to the covariance of the two data sets divided by the product of their standard deviations.

The population correlation calculation can determine whether two ranges of data move together. If the two sets of data tend to increase together, $r$ is positive. If one set tends to increase as the other tends to decrease, $r$ is negative. The value of correlation coefficient lies between -1 and +1 , inclusive. The sign of the correlation coefficient determines whether the correlation is positive or negative. The magnitude of the correlation coefficient determines the strength of the correlation. A value of +1 indicates perfect positive correlation, a value of -1 indicates perfect negative correlation and a value of zero indicates the two data sets are unrelated.

Results of the correlation calculations are shown in Table 8. Strong (defined for the purposes of this report as $0.7 \leq|\mathrm{r}| \leq 1.0)$ negative correlation existed between groundwater extraction volumes and hydraulic head for several $F$ Area locations: FPZ001A, FPZ002A, FPZ003A, FPZ004A, and FPZ007A. Strong negative correlation also existed for $\mathrm{H}$ Area locations HPZ002A and HPZ005A. The negative value indicated the expected result that higher volumes of groundwater extraction corresponded to lower hydraulic head elevations.

Correlation coefficients calculated for the reference piezometers and the remaining $\mathrm{F}$ - and H-Area piezometers, except HPZ003A, were moderate (defined for the purposes of this report as $0.5 \leq|\mathrm{r}|<0.6)$ or moderately strong $(0.6 \leq|\mathrm{r}|$ $<0.7)$ and negative. Correlation was the weakest at HPZ003A, with a correlation coefficient of -0.46. Results for HPZ006A differed from all other locations in that the correlation coefficient was positive, indicating that higher volumes of groundwater extraction correlated to higher hydraulic head elevations at that location. However, the beaver dams in Fourmile Branch influenced hydraulic head at HPZ003A and HPZ006A. 
Hydraulic heads at most F-Area locations and two H-Area locations also were strongly positively correlated to cumulative rainfall deficit/surplus (Table 8). HPZ006A results were notable due to a negative, though very low, correlation between hydraulic head elevation and rainfall deficit. Correlation to monthly rainfall was positive and fairly low at all locations.

While the correlation coefficient is useful as an estimation of the strength of linear relationship between two data sets, the presence of a strong correlation does not necessarily indicate a cause and effect relationship between the two parameters.

\section{Conclusions}

The average decrease in hydraulic head elevation for the reference piezometers $(2.1 \mathrm{ft})$ exceeded both the F-Area $(0.8 \mathrm{ft})$ and H-Area $(0.7 \mathrm{ft})$ piezometers, a phenomenon that has not been seen since the WTUs began full time operation. The magnitude of the decrease at the reference locations reflects the ongoing drought in 2002. The more moderate decreases in hydraulic head in $\mathrm{F}$ and $\mathrm{H}$ Areas reflect the opposing influences of drought and reductions in groundwater extraction.

The continued operation of the WTUs in 2002 affected hydraulic head most notably in the piezometers located closest to the extraction wells. The greatest decreases in average hydraulic head in $\mathrm{H}$ Area continued to be in the piezometers closest to the extraction wells. However, decreasing groundwater extraction in the second half of the year moderated hydraulic head declines in F Area near the extraction wells. In both areas, piezometers near the extraction wells also showed the most dramatic rises in groundwater following reduction in groundwater extraction. As in previous years, outage periods were visible on the hydrographs for piezometers FPZ004A, HPZ002A and HPZ005A as steady increases in hydraulic head not attributable to rainfall. Strong negative correlation coefficients calculated for groundwater extraction volumes and hydraulic head at many locations supported the observations.

However, WTU groundwater extraction was not the only cause of the decline in hydraulic head levels during 2002. Four consecutive years of below average rainfall was a major contributor. A correlation analysis indicated that hydraulic head was strongly correlated to cumulative rainfall deficit/surplus at many locations.

Wetlands are defined by the presence of hydric soils, saturated soil conditions during a portion of the growing season, and vegetation adapted to live in saturated soils. Lowering groundwater levels for a prolonged period could change the wetland hydrologic conditions and the vegetation growing in these areas. In many locations, the hydraulic head never reached the root zone during 2002. For several years, the water table has remained below levels required to sustain the herbaceous components of wetland vegetation at some locations. Such hydrologic conditions may allow early successional species to germinate in these areas. In other areas, changes already have occurred. Nelson (2001) documented changes in herbaceous species diversity and establishment of early successional non-wetland species due to declines in water levels in recent years in the F- and H-Area tree kill zones (FPZ005A and HPZ001A are located here), areas where tree mortality in seepline-fed wetlands downslope from the seepage basins was first identified in the 1970s. However, these changes would not cause the areas to lose their wetland classification.

\section{References}

Dixon, K. L. 1996. Monitoring of the Water Levels in the Wetlands of Fourmile Branch near the F- and H-Areas of SRS. WSRC-TR-960289. Westinghouse Savannah River Company, Savannah River Technology Center, Aiken SC.

Dixon, K. L., V. A. Rogers, and B. B. Looney. 1993. Results of the Quarterly Tritium Survey of Four Mile Creek and its Seeplines in the F- and H- Areas of SRS: September 1993. WSRC-TR93-286, Rev. 1. Westinghouse Savannah River Company, Savannah River Technology Center, Aiken SC. 
Dixon, K. L. and V. A. Rogers. 1993. Semiannual Sampling of Fourmile Branch and its Seeplines in the F- and H-Areas of SRS: July 1992. WSRC-TR-93-289. Westinghouse Savannah River Company, Savannah River Technology Center, Aiken SC.

Dixon, K. L., V. A. Rogers, and B. B. Looney. 1994. Results of the Quarterly Tritium Survey of Fourmile Branch and its Seeplines in the F- and H-Areas of SRS: September 1993. WSRC-TR94-0286. Westinghouse Savannah River Company, Savannah River Technology Center, Aiken, SC.

Flach, G. P. 1998. Impact of F- and H-Area Pump-Treat-Reinject Remediation Systems on the Old Radioactive Waste Burial Ground. SRTEST-98-154. Westinghouse Savannah River Company, Savannah River Technology Center, Aiken, SC.

Halverson, N. V. 2000. Monitoring of the Water Levels in the Wetlands of Fourmile Branch near the F and H Areas of SRS: January 1999 to December 1999. WSRC-TR-2000-00122. Westinghouse Savannah River Company, Savannah River Technology Center, Aiken SC.

Halverson, N. V. 2002. Results of Monitoring Water Levels in the Wetlands of Fourmile Branch near the F and H Areas of SRS: January to December 2001. WSRC-TR-2002-00105. Westinghouse Savannah River Company, Savannah River Technology Center, Aiken SC.

Halverson, N. V. and K. L. Dixon. 1999. Monitoring of the Water Levels in the Wetlands of Fourmile Branch near the $\mathrm{F}$ and $\mathrm{H}$ Areas of SRS: September 1997 to December 1998. WSRC-TR-99-00237. Westinghouse Savannah River Company, Savannah River Technology Center, Aiken SC.

Haselow, J. S., M. Harris, B. B. Looney, N. V. Halverson, and J. B. Gladden. 1990. Analysis of Soil and Water at the Four Mile Creek Seepline near the F- and H-Areas of SRS. WSRC-RP-900591. Westinghouse Savannah River Company, Savannah River Technology Center, Aiken SC.
Killian, T. H., N. L. Kolb, P. Corbo, and I. W. Marine. 1985a. F-Area Seepage Basins. DPST-85-704, E.I. du Pont de Nemours and Company, Savannah River Laboratory, Aiken, SC.

Killian, T. H., N. L. Kolb, P. Corbo, and I. W. Marine. 1985b. H-Area Seepage Basins. DPST-85-706, E.I. du Pont de Nemours and Company, Savannah River Laboratory, Aiken, SC.

Long, H. 2001. Inter-Office Memorandum to N. V. Halverson, dated February 28, transmitting data on F- and H-Area extraction well pumping rates. Westinghouse Savannah River Company, Savannah River Technology Center, Aiken, SC.

Long, H. 2002a. Inter-Office Memorandum to J. Brantley, dated January 29, transmitting data on F- and $\mathrm{H}$-Area extraction well pumping rates. Westinghouse Savannah River Company, Savannah River Technology Center, Aiken, SC.

Long, H. 2002b. Inter-Office Memorandum to N. V. Halverson, dated August 14, 2002. transmitting data on F- and H-Area monthly extraction well pumping volumes for January through June 2002. Westinghouse Savannah River Company, Savannah River Technology Center, Aiken, SC.

Long, H. 2003a. Inter-Office Memorandum to N. V. Halverson, dated January 29, 2003. transmitting data on F- and H-Area monthly extraction well pumping volumes for July through December 2002. Westinghouse Savannah River Company, Savannah River Technology Center, Aiken, SC.

Long, H. 2003b. Inter-Office Memorandum to N. V. Halverson, dated January 30, 2003. transmitting data on $\mathrm{F}$ - and $\mathrm{H}$-Area daily extraction well pumping volumes for July through December 2002. Westinghouse Savannah River Company, Savannah River Technology Center, Aiken, SC. 
Long, H. 2003c. Inter-Office Memorandum to N. V. Halverson, dated February 3, 2003. transmitting data on F- and H-Area daily extraction well pumping volumes for January through June 2002. Westinghouse Savannah River Company, Savannah River Technology Center, Aiken, SC.

Nelson, E. A. 2001. Plant Community Development within the F- and H-Area TreeKill Zones - 2001 Characterization. WSRC-TR2001-00448. Westinghouse Savannah River Company, Savannah River Technology Center, Aiken, SC.

Sadler, W. R. 1995. Groundwater Model Recalibration and Remediation Well Network Design at the F-Area Seepage Basins. WSRCRP-95-237. Westinghouse Savannah River Company, Savannah River Technology Center, Aiken, SC.

SCDNR 2002a. Drought Upgraded to Extreme for 39 South Carolina Counties. Special News Release \#02, July 24. South Carolina Department of Natural Resources Columbia, South Carolina

SCDNR 2002b. Drought Conditions Downgraded Statewide. Special News Release \#02-53, November 21. South Carolina Department of Natural Resources Columbia, South Carolina

USCOE 1987. Corps of Engineers Wetlands Delineation Manual, Technical Report Y-87-1. United States Corps of Engineers, Washington, D.C.

Wells, L. 2001. Inter-Office Memorandum to N. V. Halverson, dated August 15, 2001, transmitting data on F- and H-Area extraction well pumping rates. Westinghouse Savannah River Company, Aiken, SC.

WSRC 1997a. F-Area Hazardous Waste Management Facility Corrective Action Report, First and Second Quarters 1997, Volume I. WSRC-TR-97-0216. Westinghouse Savannah River Company, Aiken, SC
WSRC 1997b. H-Area Hazardous Waste Management Facility Corrective Action Report, First and Second Quarters 1997, Volume I. WSRC-TR-97-0240. Westinghouse Savannah River Company, Aiken, SC

WSRC 1998a. F-Area Hazardous Waste Management Facility Corrective Action Report, Third and Fourth Quarters 1997, Volume I. WSRC-TR-98-00003. Westinghouse Savannah River Company, Aiken, SC

WSRC 1998b. H-Area Hazardous Waste Management Facility Corrective Action Report, Third and Fourth Quarters 1997, Volume I. WSRC-TR-98-00004. Westinghouse Savannah River Company, Aiken, SC

WSRC 1998c. F-Area Hazardous Waste Management Facility Corrective Action Report, First and Second Quarters 1998, Volume I. WSRC-TR-98-00147. Westinghouse Savannah River Company, Aiken, SC

WSRC 1998d. H-Area Hazardous Waste Management Facility Corrective Action Report, First and Second Quarters 1998, Volume I. WSRC-TR-98-00147. Westinghouse Savannah River Company, Aiken, SC

WSRC 1999a. F-Area Hazardous Waste Management Facility Corrective Action Report, Third and Fourth Quarters 1998, Volume I. WSRC-TR-99-00012. Westinghouse Savannah River Company, Aiken, SC

WSRC 1999b. H-Area Hazardous Waste Management Facility Corrective Action Report, Third and Fourth Quarters 1998, Volume I. WSRC-TR-99-00013. Westinghouse Savannah River Company, Aiken, SC

WSRC 1999c. F-Area Hazardous Waste Management Facility Semiannual Corrective Action Report, First and Second Quarters 1999, Volume I. WSRC-TR-99-00147. Westinghouse Savannah River Company, Aiken, SC

WSRC 1999d. H-Area Hazardous Waste Management Facility Semiannual Corrective Action Report, First and Second Quarters 1999, Volume I. WSRC-TR-99-00148. Westinghouse Savannah River Company, Aiken, SC 
WSRC 2000a. F-Area Hazardous Waste

Management Facility Corrective Action Report,

Third and Fourth Quarters 1999, Volume I.

WSRC-TR-99-000266. Westinghouse

Savannah River Company, Aiken, SC

WSRC 2000b. H-Area Hazardous Waste

Management Facility Corrective Action Report,

Third and Fourth Quarters 1999, Volume I.

WSRC-TR-99-00267 Westinghouse Savannah

River Company, Aiken, SC

WSRC 2000c. F-Area Hazardous Waste

Management Facility Corrective Action Report,

First and Second Quarter 2000, Volume I.

WSRC-TR-2000-00243. Westinghouse

Savannah River Company, Aiken, SC

WSRC 2000d. H-Area Hazardous Waste

Management Facility Corrective Action Report,

First and Second Quarter 2000, Volume I.

WSRC-TR-2000-00244. Westinghouse

Savannah River Company, Aiken, SC

WSRC 2001a. F-Area Hazardous Waste

Management Facility Corrective Action Report,

Third and Fourth Quarter 2000, Volume I.

WSRC-TR-2001-4010. Westinghouse

Savannah River Company, Aiken, SC

WSRC 2001b. H-Area Hazardous Waste

Management Facility Corrective Action Report,

Third and Fourth Quarter 2000, Volume I.

WSRC-TR-2001-4009. Westinghouse

Savannah River Company, Aiken, SC 


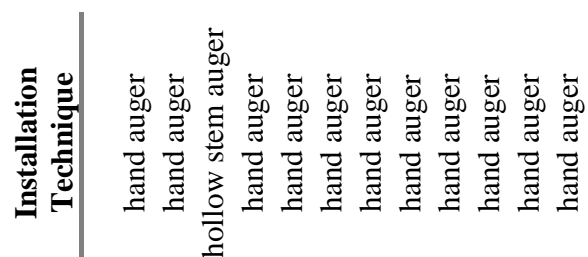

竎

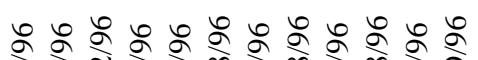

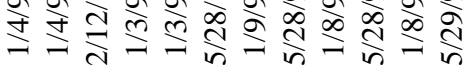

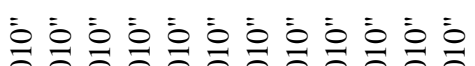

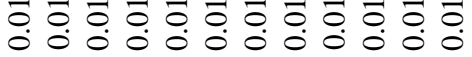

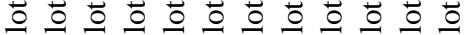

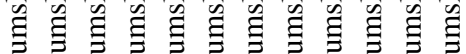

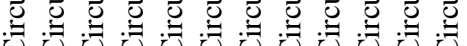
U U U U U U U U U U U U U U

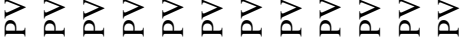

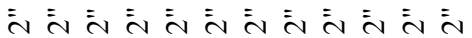

ขึ $\cup \cup \cup \cup \cup \cup \cup \cup \cup \cup \cup \cup$

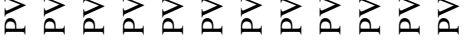

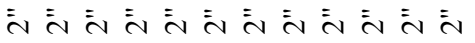

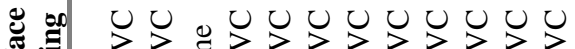

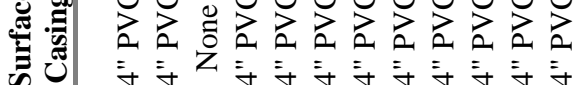
\&. 䓂高苞 혈

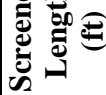

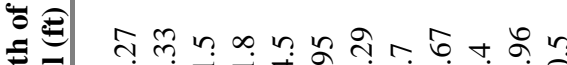

言竞

유 8응ㅇㅇㅇㅇ유유우 ล்

nก

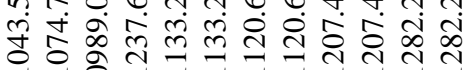

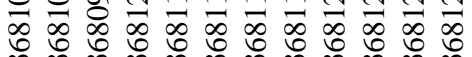

ดิ ํำ

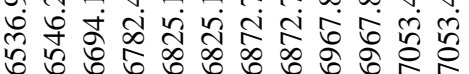

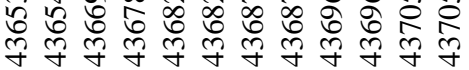

焉

:

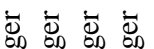

స స స

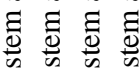

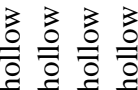

ㄴ. 2

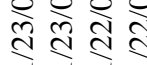

흥흥흥흥

$\circ \stackrel{0}{0} \dot{0}$

흥ㅎㅁ

気泀泀

氙

0 U U

召召文吕

취 $\bar{\nu}$

$\cup \cup \cup 0$

a文文吕

i $\bar{\omega} \bar{\nu}$

芒芒芒芒

西

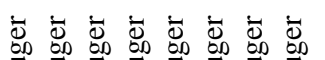

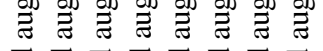

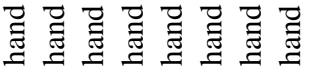

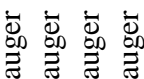

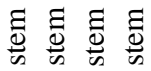

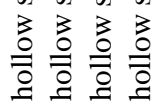

空

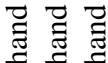

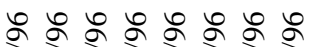

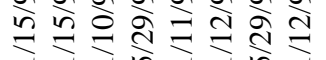

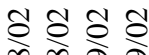

के

רI

흥흥흫ㅎㅎㅎㅎ흥흥

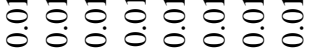

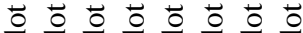

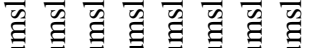

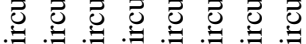

ช己

U U U U U U U U

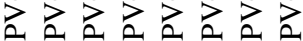

$\bar{\nu} \bar{\omega} \bar{\omega} \bar{\nu} \bar{\omega}$

$\cup \cup \cup \cup \cup \cup \cup \cup$

召召召召召召召

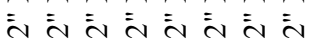

흥흥흥흥흥흥

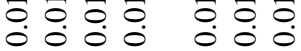

$\overrightarrow{0} \overrightarrow{0}$

彭

记进

U U U U

召召召吕

i $\bar{i} \bar{i}$

$\cup \cup \cup 0$

王文文吕

$\bar{\nu} \bar{\nu} \bar{\nu}$

흠 흠 훔

言

$\cup \cup 0$

文吕文

$\bar{i} \equiv$

$\cup \circlearrowright U$

a文

స

$\cup \cup \cup \cup \cup \cup \cup \cup$

ฮี ซี ซี

$\cup \cup$

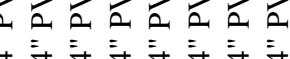

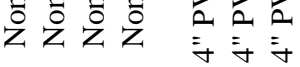

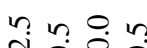

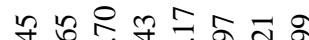

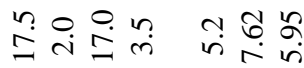

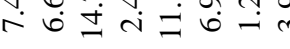

o. 00

눈은

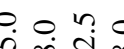

ํ.

$\circ \circ 0.0$

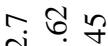
$=\infty$

$n$ ㄷ. $n$

와아아용요

$\infty \infty \infty$

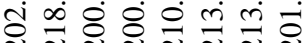

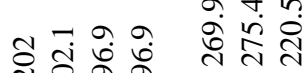

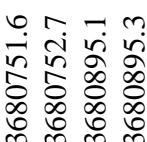

भें

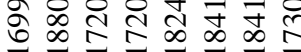

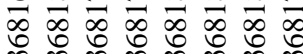

तथ

0.006

ㅊํㄴ

正

oे $\infty$ aे

$\infty$

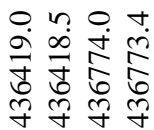

$\infty$ 舟

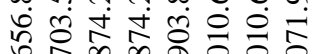

วิํํำ

苹守

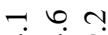

$\infty \infty \infty$

F

सें के

尔主良

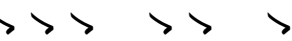

$>>$

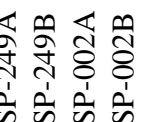

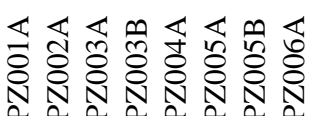

苾

ธิे จे

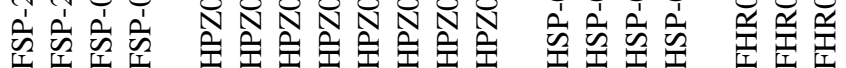


Table 2 Groundwater extraction (thousands of gallons) by the F-Area Groundwater Remediation Wastewater Treatment Unit, 1997 to 2002

\begin{tabular}{|c|c|c|c|c|c|c|c|c|c|c|c|c|c|}
\hline Well ID & Jan & Feb & Mar & Apr & May & Jun & Jul & Aug & Sep & Oct & Nov & Dec & Total \\
\hline 1997 & & & & & & & & & & & & & \\
\hline TOTAL & 0 & 0 & 0 & 10 & 29 & 29 & 40 & 411 & 189 & 235 & 173 & 560 & 1,676 \\
\hline 1998 & & & & & & & & & & & & & \\
\hline TOTAL & 570 & 547 & 390 & 0 & 0 & 0 & 1,214 & 3,468 & 2,448 & 3,137 & 1,680 & 1,173 & 14,627 \\
\hline 1999 & & & & & & & & & & & & & \\
\hline TOTAL & 842 & 573 & 913 & 4,621 & 4,626 & 1,106 & 1,397 & 3,883 & 6,739 & 7,615 & 6,565 & 7,683 & 46,562 \\
\hline 2000 & & & & & & & & & & & & & \\
\hline TOTAL & 7,586 & 6,093 & 7,593 & 7,363 & 6,404 & 7,302 & 7,529 & 6,624 & 6,381 & 7,530 & 7,231 & 7,098 & 84,739 \\
\hline 2001 & & & & & & & & & & & & & \\
\hline TOTAL & 7,413 & 5,750 & 7,510 & 7,318 & 7,611 & 6,892 & 7,504 & 7,521 & 6,846 & 6,563 & 7,434 & 7,220 & 85,576 \\
\hline 2002 & & & & & & & & & & & & & \\
\hline FEX-1 & 1,293 & 1,221 & 1,378 & 1,213 & 1,238 & 1,308 & 1,584 & 925 & 145 & 242 & 555 & 738 & 11,838 \\
\hline FEX-2 & 1,301 & 1,319 & 1,241 & 1,087 & 1,390 & 778 & 1,125 & 813 & 132 & 117 & 229 & 243 & 9,773 \\
\hline FEX-3 & 1,123 & 1,015 & 1,152 & 995 & 1,060 & 949 & 1,173 & 696 & 122 & 57 & 304 & 356 & 9,000 \\
\hline FEX-4 & 1,127 & 1,068 & 1,211 & 1,047 & 1,179 & 114 & 633 & 784 & 203 & 152 & 610 & 610 & 8,739 \\
\hline FEX-5 & 231 & 220 & 239 & 210 & 236 & 27 & 152 & 135 & 237 & 286 & 214 & 267 & 2,455 \\
\hline FEX-6 & 733 & 563 & 706 & 661 & 715 & 78 & 399 & 524 & 701 & 516 & 510 & 680 & 6,786 \\
\hline FEX-7 & 894 & 834 & 912 & 781 & 885 & 95 & 450 & 656 & 830 & 629 & 562 & 829 & 8,355 \\
\hline FEX-8 & 341 & 293 & 348 & 305 & 346 & 34 & 192 & 195 & 311 & 330 & 108 & 0 & 2,802 \\
\hline FEX-9 & 341 & 375 & 353 & 300 & 412 & 36 & 197 & 203 & 303 & 429 & 103 & 0 & 3,052 \\
\hline FEX-10 & 0 & 0 & 0 & 0 & 0 & 0 & 2 & 0 & 353 & 537 & 12 & 2 & 905 \\
\hline FEX-11 & 0 & 0 & 0 & 0 & 0 & 0 & 0 & 0 & 370 & 505 & 10 & 69 & 955 \\
\hline TOTAL & 7,383 & 6,907 & 7,540 & 6,599 & 7,460 & 3,420 & 5,906 & 4,931 & 3,706 & 3,798 & 3,218 & 3,794 & 64,660 \\
\hline
\end{tabular}

Sources: $\quad$ Long (2001, 2002a\&b, 2003a), Wells (2001), WSRC (1997a, 1998a\&c, 1999a\&c, 2000a\&c, 2001a) 
Table 3 Groundwater extraction (thousands of gallons) by the H-Area Groundwater Remediation Wastewater Treatment Unit, 1997 to 2002

\begin{tabular}{|c|c|c|c|c|c|c|c|c|c|c|c|c|c|}
\hline Well ID & Jan & Feb & Mar & Apr & May & Jun & Jul & Aug & Sep & Oct & Nov & Dec & Total \\
\hline 1997 & & & & & & & & & & & & & \\
\hline TOTAL & 0 & 0 & 0 & 0 & 0 & 0 & 20 & 0 & 792 & 192 & 23 & 206 & 1,234 \\
\hline 1998 & & & & & & & & & & & & & \\
\hline TOTAL & 133 & 598 & 1,930 & 312 & 0 & 1,227 & 2,142 & 1,805 & 2,494 & 2,298 & 90 & 2,078 & 15,107 \\
\hline 1999 & & & & & & & & & & & & & \\
\hline TOTAL & 1,062 & 3,401 & 4,458 & 4,013 & 2,582 & 6,072 & 6,291 & 6,119 & 5,665 & 6,340 & 5,762 & 6,262 & 58,027 \\
\hline 2000 & & & & & & & & & & & & & \\
\hline TOTAL & 6,285 & 5,581 & 6,285 & 6,006 & 5,724 & 5,990 & 6,231 & 6,049 & 5,899 & 6,229 & 6,061 & 6,181 & 72,525 \\
\hline 2001 & & & & & & & & & & & & & \\
\hline TOTAL & 6,033 & 5,695 & 6,196 & 6,013 & 6,123 & 6,052 & 6,263 & 2,696 & 5,788 & 6,312 & 6,108 & 6,299 & 69,577 \\
\hline 2002 & & & & & & & & & & & & & \\
\hline HEX-1 & 1,025 & 853 & 1,012 & 932 & 988 & 940 & 1,000 & 937 & 833 & 894 & 800 & 305 & 10,519 \\
\hline HEX-2 & 0 & 44 & 0 & 0 & 0 & 0 & 125 & 235 & 231 & 220 & 210 & 168 & 1,233 \\
\hline HEX-3 & 833 & 669 & 864 & 777 & 849 & 820 & 862 & 802 & 801 & 773 & 731 & 293 & 9,071 \\
\hline HEX-4 & 604 & 481 & 613 & 571 & 583 & 520 & 507 & 486 & 476 & 507 & 492 & 240 & 6,079 \\
\hline HEX-9 & 355 & 313 & 356 & 341 & 349 & 333 & 329 & 400 & 418 & 445 & 452 & 351 & 4,442 \\
\hline HEX-12 & 206 & 181 & 212 & 193 & 209 & 198 & 158 & 614 & 633 & 666 & 629 & 281 & 4,178 \\
\hline HEX-16 & 0 & 0 & 0 & 0 & 0 & 0 & 0 & 0 & 0 & 0 & 0 & 217 & 217 \\
\hline HEX-17 & 1,797 & 1,622 & 1,892 & 1,717 & 1,898 & 1,810 & 1,852 & 1,544 & 1,558 & 1,604 & 1,551 & 633 & 19,477 \\
\hline HEX-18 & 1,193 & 1,056 & 1,247 & 1,119 & 1,198 & 1,286 & 1,220 & 1,160 & 1,009 & 1,075 & 1,070 & 378 & 13,011 \\
\hline HEX-19 & 111 & 106 & 123 & 106 & 127 & 102 & 99 & 87 & 111 & 111 & 120 & 97 & 1,298 \\
\hline TOTAL & 6,123 & 5,326 & 6,318 & 5,755 & 6,199 & 6,008 & 6,152 & 6,263 & 6,071 & 6,294 & 6,054 & 2,964 & 69,526 \\
\hline
\end{tabular}

Sources: $\quad$ Long (2001, 2002a\&b, 2003a), Wells (2001), WSRC (1997b, 1998b\&d, 1999b\&d, 2000b\&d, 2001b) 


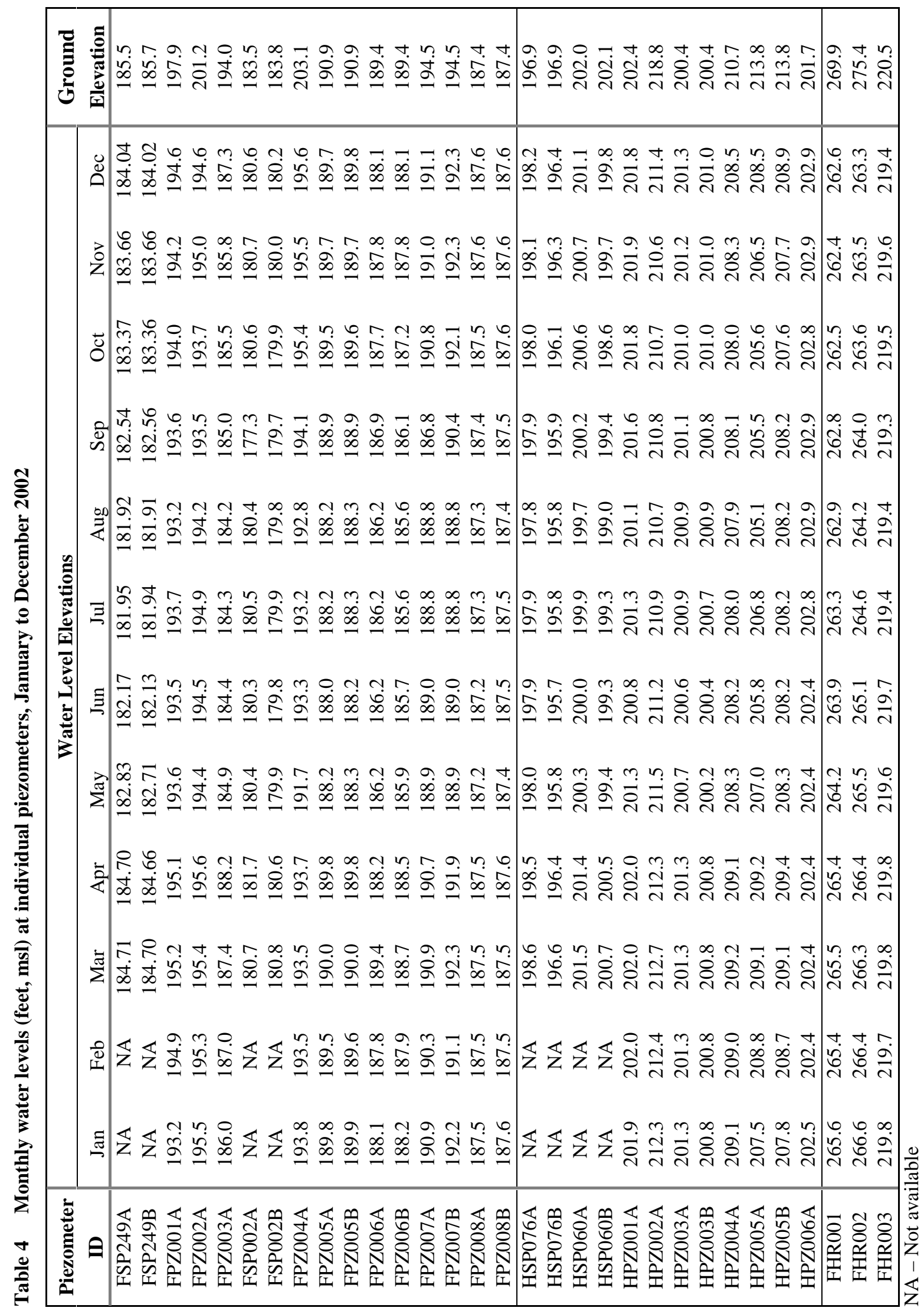


Table 5 Maximum, minimum and average water level measurements, January to December 2002

\begin{tabular}{|c|c|c|c|c|c|c|c|c|c|c|c|c|}
\hline \multirow[b]{2}{*}{$\begin{array}{c}\text { Piez. } \\
\text { ID }\end{array}$} & \multicolumn{6}{|c|}{ Monthly Measurements } & \multicolumn{6}{|c|}{ Continuous Measurements } \\
\hline & $\begin{array}{c}\text { Max. } \\
\text { Water } \\
\text { Level } \\
(\mathrm{ft}, \mathrm{msl})\end{array}$ & $\begin{array}{c}\text { Min. } \\
\text { Water } \\
\text { Level } \\
(\mathrm{ft}, \mathrm{msl})\end{array}$ & $\begin{array}{l}\text { Avg. } \\
\text { Water } \\
\text { Level } \\
(\mathrm{ft}, \mathrm{msl})\end{array}$ & $\begin{array}{l}\text { Change } \\
\text { from } \\
2001 \\
\text { Avg. } \\
(\mathrm{ft})^{\mathrm{a}}\end{array}$ & $\begin{array}{c}\text { Range } \\
(\mathrm{ft})\end{array}$ & $\begin{array}{c}\text { Std. } \\
\text { Dev. } \\
\text { (ft) }\end{array}$ & $\begin{array}{c}\text { Max. } \\
\text { Water } \\
\text { Level } \\
(\mathrm{ft}, \mathrm{msl})\end{array}$ & $\begin{array}{c}\text { Min. } \\
\text { Water } \\
\text { Level } \\
(\mathrm{ft}, \mathrm{msl})\end{array}$ & $\begin{array}{l}\text { Avg. } \\
\text { Water } \\
\text { Level } \\
\text { (ft, msl) }\end{array}$ & $\begin{array}{l}\text { Change } \\
\text { from } \\
2001 \\
\text { Avg. } \\
(\mathrm{ft})^{\mathrm{a}}\end{array}$ & $\begin{array}{l}\text { Range } \\
(\mathrm{ft})\end{array}$ & $\begin{array}{r}\text { Std. } \\
\text { Dev. } \\
\text { (ft) }\end{array}$ \\
\hline FSP249A & 184.7 & 181.9 & 183.2 & NA & 2.8 & 1.1 & NA & NA & NA & NA & NA & NA \\
\hline FSP249B & 184.7 & 181.9 & 183.2 & NA & 2.8 & 1.1 & NA & NA & NA & NA & NA & NA \\
\hline FPZ001A & 195.2 & 193.2 & 194.1 & -1.4 & 2.0 & 0.7 & 195.6 & 193.0 & 194.2 & -2.0 & 2.6 & 0.6 \\
\hline FPZ002A & 195.6 & 193.5 & 194.7 & -1.5 & 2.1 & 0.7 & 196.3 & 194.1 & 195.0 & -1.0 & 2.2 & 0.5 \\
\hline FPZ003A & 188.2 & 184.2 & 185.8 & -1.0 & 4.1 & 1.4 & 189.2 & 183.9 & 185.9 & -1.4 & 5.4 & 1.3 \\
\hline FSP002A & 181.7 & 177.3 & 180.3 & NA & 4.4 & 1.1 & NA & NA & NA & NA & NA & NA \\
\hline FSP002B & 180.8 & 179.7 & 180.1 & NA & 1.1 & 0.4 & NA & NA & NA & NA & NA & NA \\
\hline FPZ004A & 195.6 & 191.7 & 193.9 & -0.8 & 3.8 & 1.2 & 196.5 & 193.0 & 194.2 & -0.3 & 3.5 & 1.1 \\
\hline FPZ005A & 190.0 & 188.0 & 189.1 & -0.6 & 1.9 & 0.8 & 190.4 & 187.3 & 189.2 & -0.6 & 3.2 & 0.7 \\
\hline FPZ005B & 190.0 & 188.2 & 189.2 & -0.5 & 1.8 & 0.7 & NA & NA & NA & NA & NA & NA \\
\hline FPZ006A & 189.4 & 186.2 & 187.4 & -0.4 & 3.2 & 1.0 & 189.1 & 185.5 & 187.5 & -0.4 & 3.6 & 0.9 \\
\hline FPZ006B & 188.7 & 185.6 & 187.1 & -0.5 & 3.0 & 1.2 & NA & NA & NA & NA & NA & NA \\
\hline FPZ007A & 191.1 & 186.8 & 189.8 & -0.9 & 4.3 & 1.4 & 192.1 & 188.2 & 190.2 & -0.5 & 3.9 & 0.9 \\
\hline FPZ007B & 192.3 & 188.8 & 190.8 & -0.6 & 3.6 & 1.6 & NA & NA & NA & NA & NA & NA \\
\hline FPZ008A & 187.6 & 187.2 & 187.4 & 0.0 & 0.4 & 0.1 & 187.9 & 187.0 & 187.5 & 0.0 & 0.9 & 0.2 \\
\hline FPZ008B & 187.6 & 187.4 & 187.5 & 0.1 & 0.1 & 0.1 & NA & NA & NA & NA & NA & NA \\
\hline HSP076A & 198.6 & 197.8 & 198.1 & NA & 0.8 & 0.3 & NA & NA & NA & NA & NA & NA \\
\hline HSP076B & 196.6 & 195.7 & 196.1 & NA & 0.8 & 0.3 & NA & NA & NA & NA & NA & NA \\
\hline HSP060A & 201.5 & 199.7 & 200.5 & NA & 1.8 & 0.6 & NA & NA & NA & NA & NA & NA \\
\hline HSP060B & 200.7 & 198.6 & 199.6 & NA & 2.1 & 0.6 & NA & NA & NA & NA & NA & NA \\
\hline HPZ001A & 202.0 & 200.8 & 201.6 & -0.3 & 1.2 & 0.4 & 202.2 & 200.6 & 201.7 & -0.2 & 1.5 & 0.4 \\
\hline HPZ002A & 212.7 & 210.6 & 211.4 & -1.9 & 2.1 & 0.8 & 214.4 & 210.6 & 211.7 & -1.5 & 3.8 & 0.8 \\
\hline HPZ003A & 201.3 & 200.6 & 201.1 & -0.1 & 0.7 & 0.3 & 201.7 & 200.6 & 201.2 & -0.1 & 1.1 & 0.3 \\
\hline HPZ003B & 201.0 & 200.2 & 200.8 & -0.1 & 0.8 & 0.2 & NA & NA & NA & NA & NA & NA \\
\hline HPZ004A & 209.2 & 207.9 & 208.5 & -0.7 & 1.3 & 0.5 & 209.4 & 207.3 & 208.5 & -0.7 & 2.1 & 0.5 \\
\hline HPZ005A & 209.2 & 205.1 & 207.1 & -1.7 & 4.1 & 1.5 & 212.1 & 205.6 & 207.6 & -1.4 & 6.5 & 1.4 \\
\hline HPZ005B & 209.4 & 207.6 & 208.3 & -0.8 & 1.8 & 0.5 & NA & NA & NA & NA & NA & NA \\
\hline HPZ006A & 202.9 & 202.4 & 202.6 & 0.1 & 0.6 & 0.2 & 203.8 & 202.3 & 202.7 & 0.0 & 1.6 & 0.2 \\
\hline FHR001 & 265.6 & 262.4 & 263.9 & -2.7 & 3.1 & 1.3 & 266.1 & 262.5 & 264.0 & -2.7 & 3.6 & 1.1 \\
\hline FHR002 & 266.6 & 263.3 & 265.0 & -3.3 & 3.3 & 1.3 & 266.8 & 263.4 & 265.0 & -3.6 & 3.4 & 1.2 \\
\hline FHR003 & 219.8 & 219.3 & 219.6 & -0.1 & 0.5 & 0.2 & $220.1^{b}$ & $219.7^{b}$ & $219.8^{b}$ & $0.2^{b}$ & $0.4^{\mathrm{b}}$ & $0.0^{\mathrm{b}}$ \\
\hline
\end{tabular}




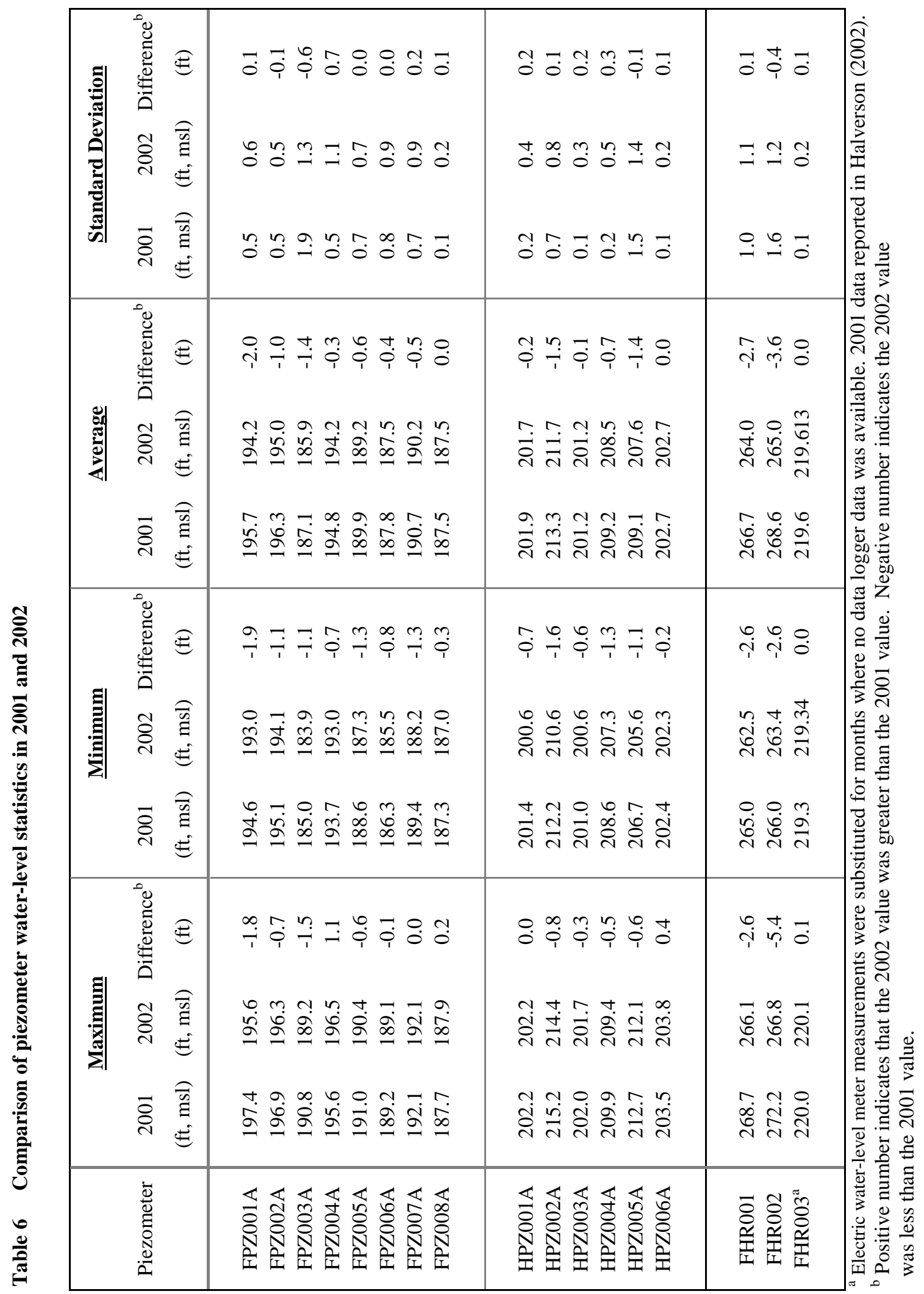




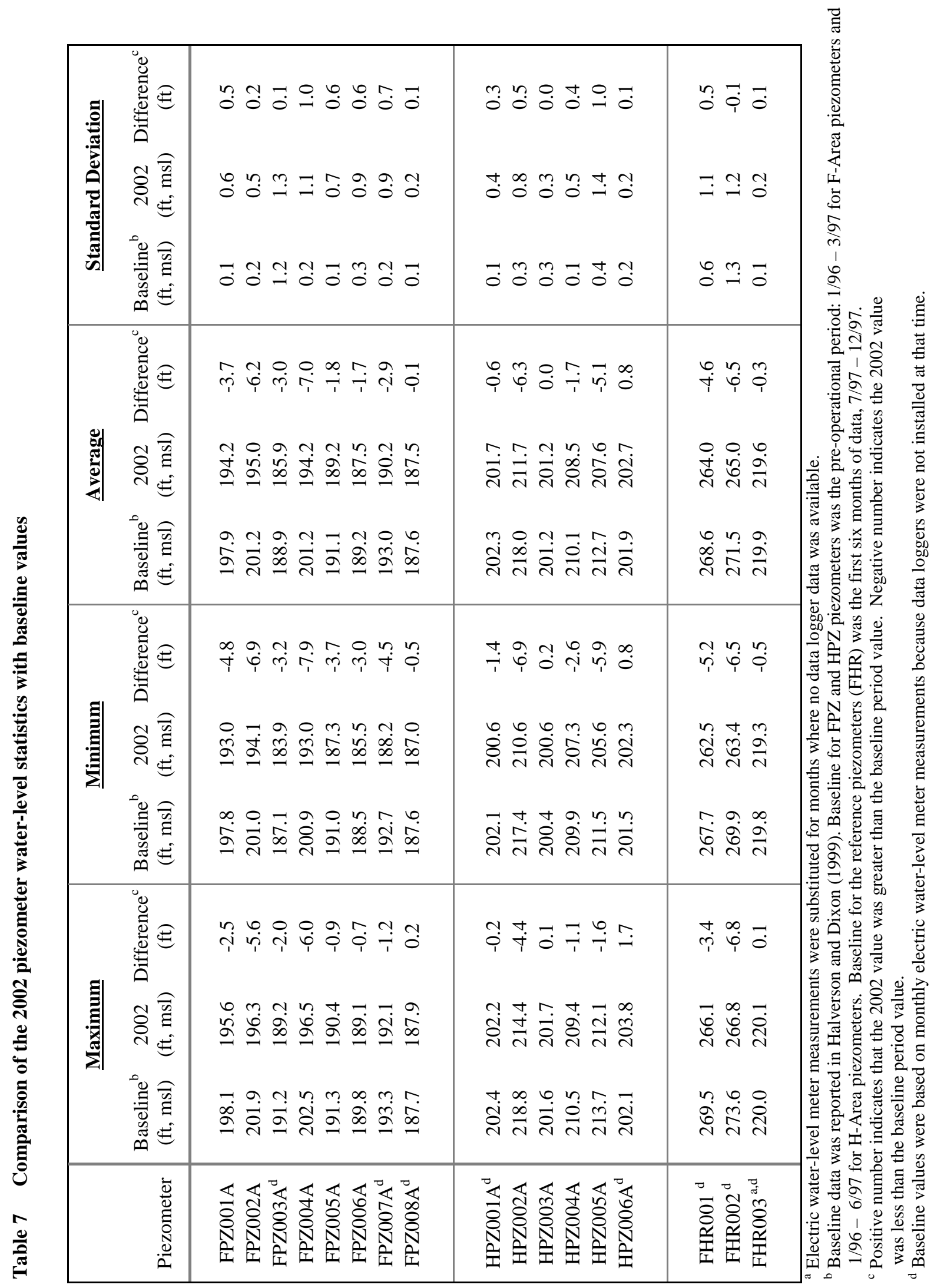


Table 8 Population Correlation Coefficients for Monthly Hydraulic Head vs. Groundwater Extraction, Temperature, Rainfall, and Cumulative Rainfall Surplus/Deficit Strong correlation coefficients are shown in bold.

\begin{tabular}{|c|c|c|c|}
\hline \multirow[b]{2}{*}{ Location } & \multicolumn{3}{|c|}{ Correlation Coefficient } \\
\hline & Extraction & $\begin{array}{c}\text { Cumulative } \\
\text { Rainfall } \\
\text { Surplus/Deficit }^{\mathrm{a}}\end{array}$ & Rainfall \\
\hline FPZ001A & -0.75 & 0.87 & 0.24 \\
\hline FPZ002A & -0.75 & 0.87 & 0.24 \\
\hline FPZ003A & -0.83 & 0.80 & 0.26 \\
\hline FPZ004A & -0.83 & 0.80 & 0.26 \\
\hline FPZ005A & -0.53 & 0.72 & 0.23 \\
\hline FPZ006A & -0.64 & 0.72 & 0.23 \\
\hline FPZ007A & -0.75 & 0.77 & 0.28 \\
\hline FPZ008A & -0.68 & 0.50 & 0.25 \\
\hline HPZ001A & -0.69 & 0.43 & 0.13 \\
\hline HPZ002A & -0.88 & 0.75 & 0.28 \\
\hline HPZ003A & -0.46 & 0.28 & 0.17 \\
\hline HPZ004A & -0.66 & 0.73 & 0.13 \\
\hline HPZ005A & -0.82 & 0.66 & 0.33 \\
\hline HPZ006A & 0.59 & -0.16 & 0.04 \\
\hline FHR001 $^{\mathrm{b}}$ & -0.62 & 0.83 & 0.23 \\
\hline FHR002 ${ }^{b}$ & -0.65 & 0.78 & 0.29 \\
\hline FHR003 $^{b}$ & -0.59 & 0.57 & 0.27 \\
\hline
\end{tabular}

${ }^{a}$ Assumed to be zero at the beginning of the program in 1996.

${ }^{\mathrm{b}}$ Correlation with H-Area data.

Table 9 Population Correlation Coefficients between Groundwater Extraction, Rainfall, and Cumulative Rainfall Surplus/Deficit

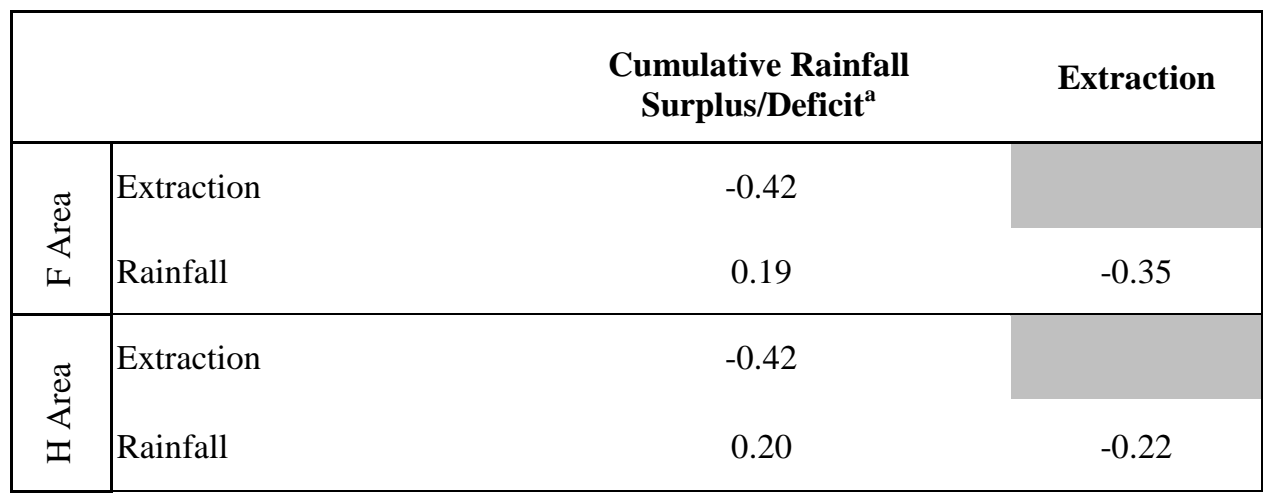

${ }^{\mathrm{a}}$ Assumed to be zero at the beginning of the program in 1996. 


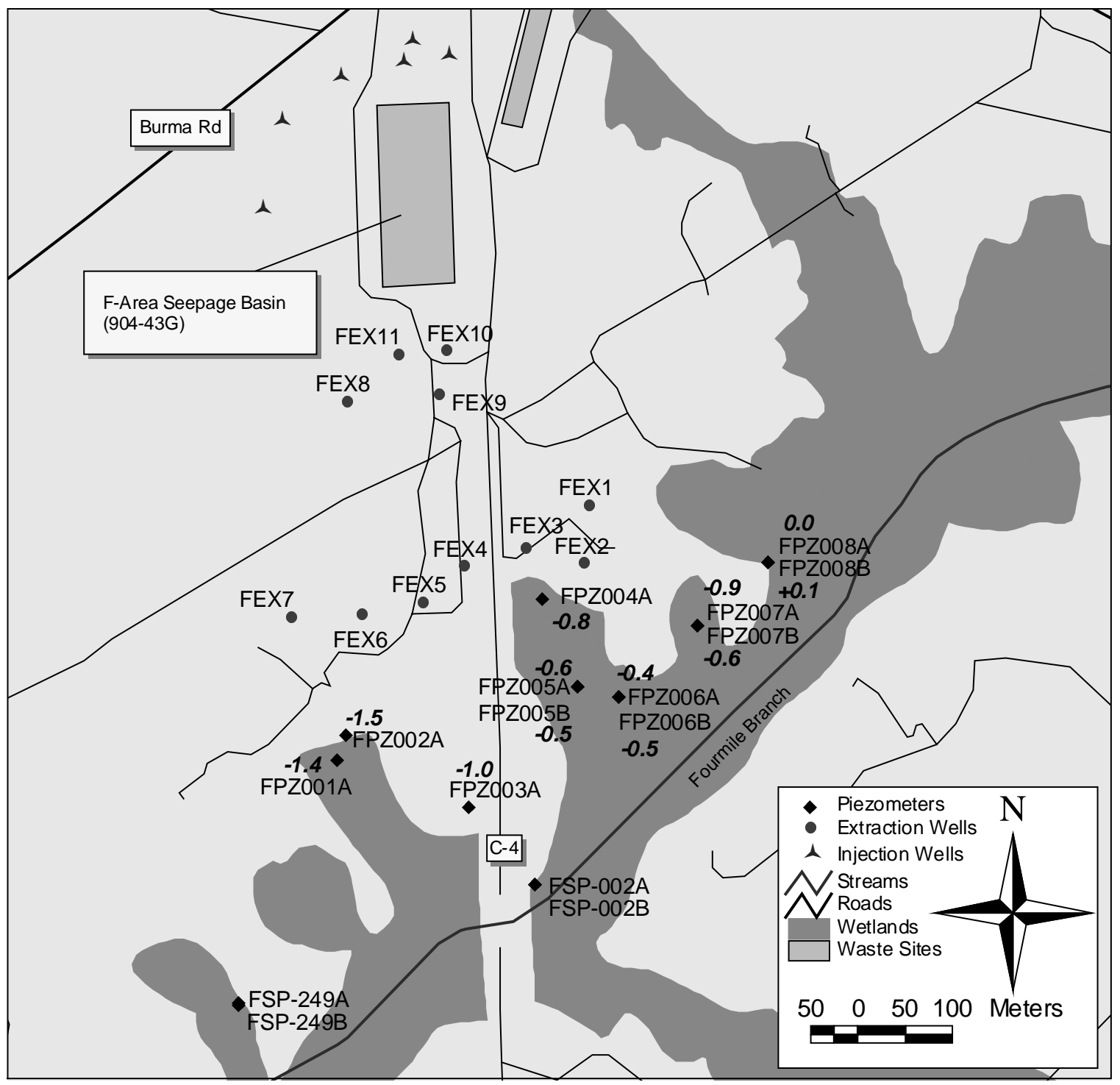

Figure 1 Extraction / injection well and piezometer locations for the water table aquifer (UAZ) in F Area Only operating extraction wells are labeled. Change in average hydraulic head elevation from 2001 to 2002 is shown in italics. 


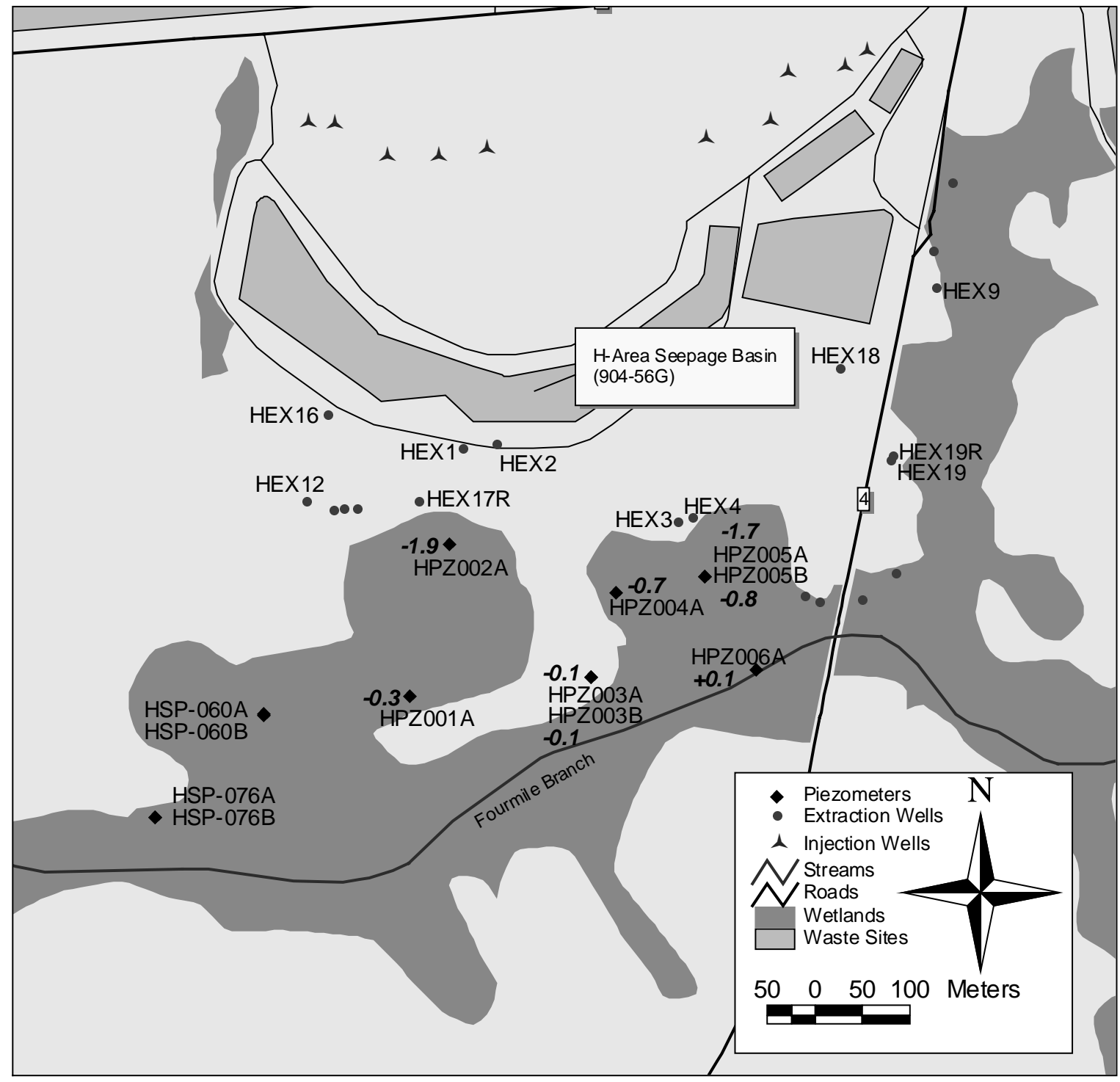

Figure 2 Extraction / injection well and piezometer locations for the water table aquifer (UAZ) in H Area Only operating extraction wells are labeled. Change in average hydraulic head elevation from 2001 to 2002 is shown in italics. 


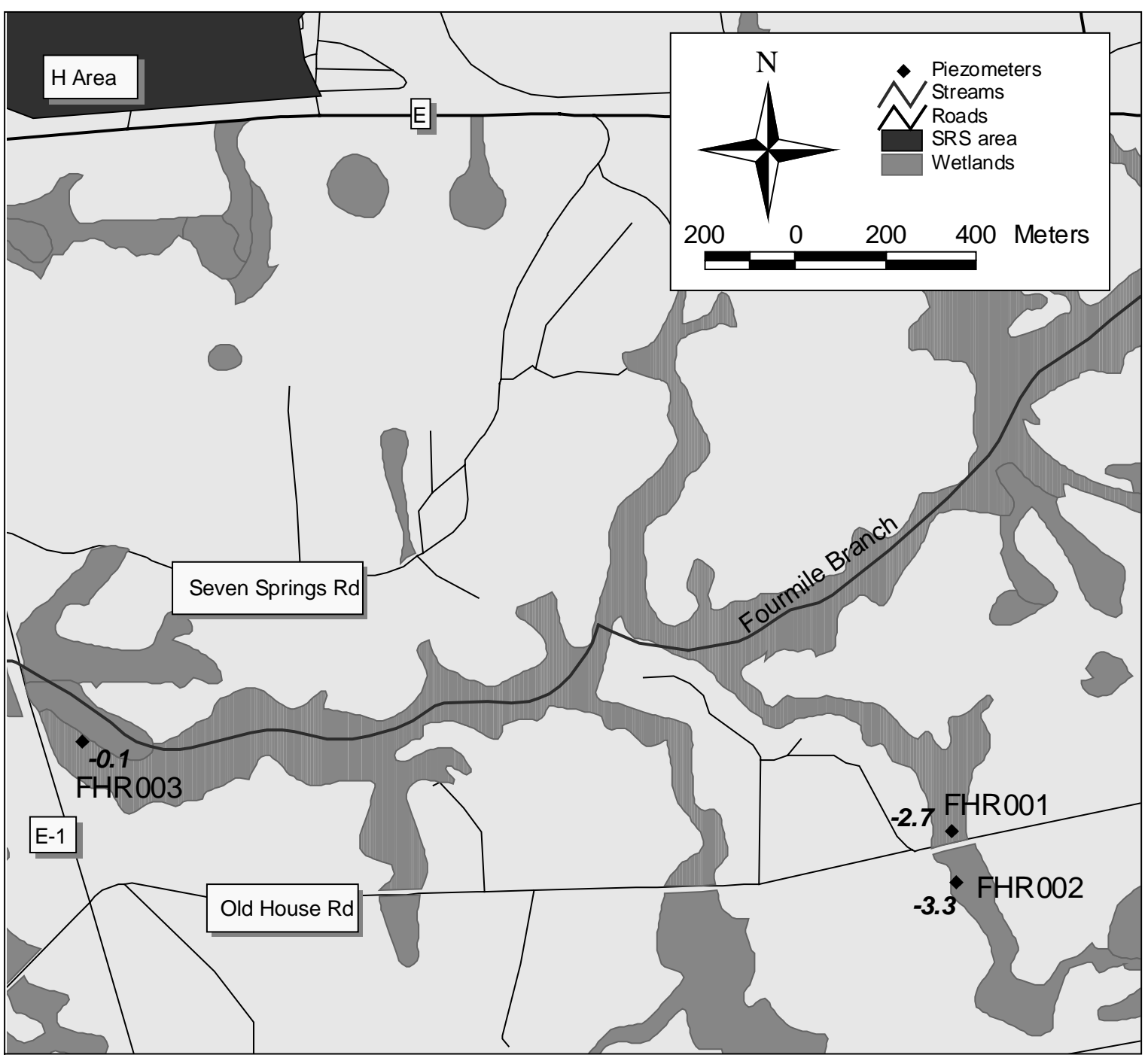

Figure 3 Reference piezometer locations

Change in average hydraulic head elevation from 2001 to 2002 is shown in italics. 

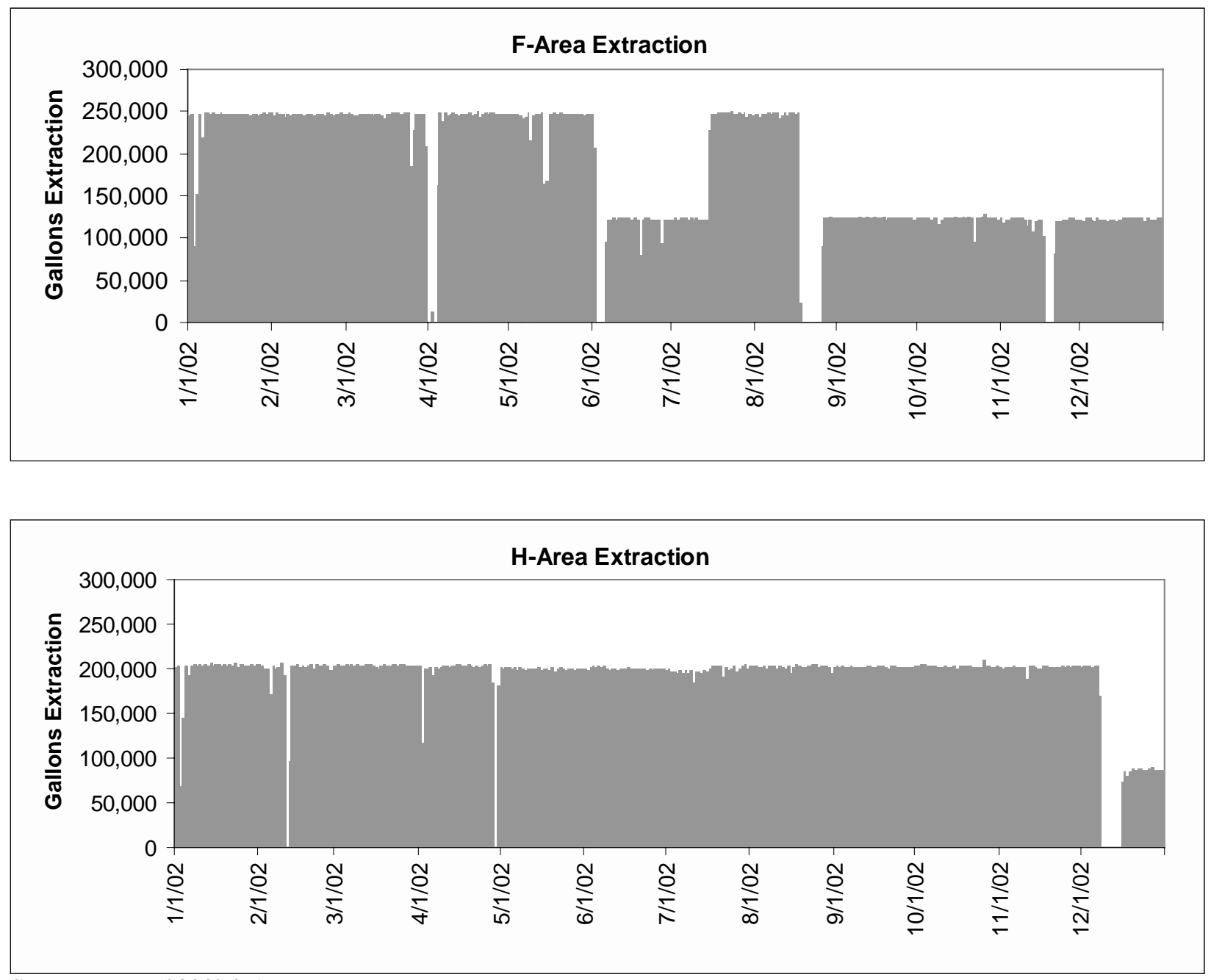

Source: Long (2003b\&c)

Figure 4 Groundwater extraction rates (gal/day) in F Area and H Area, 2002 

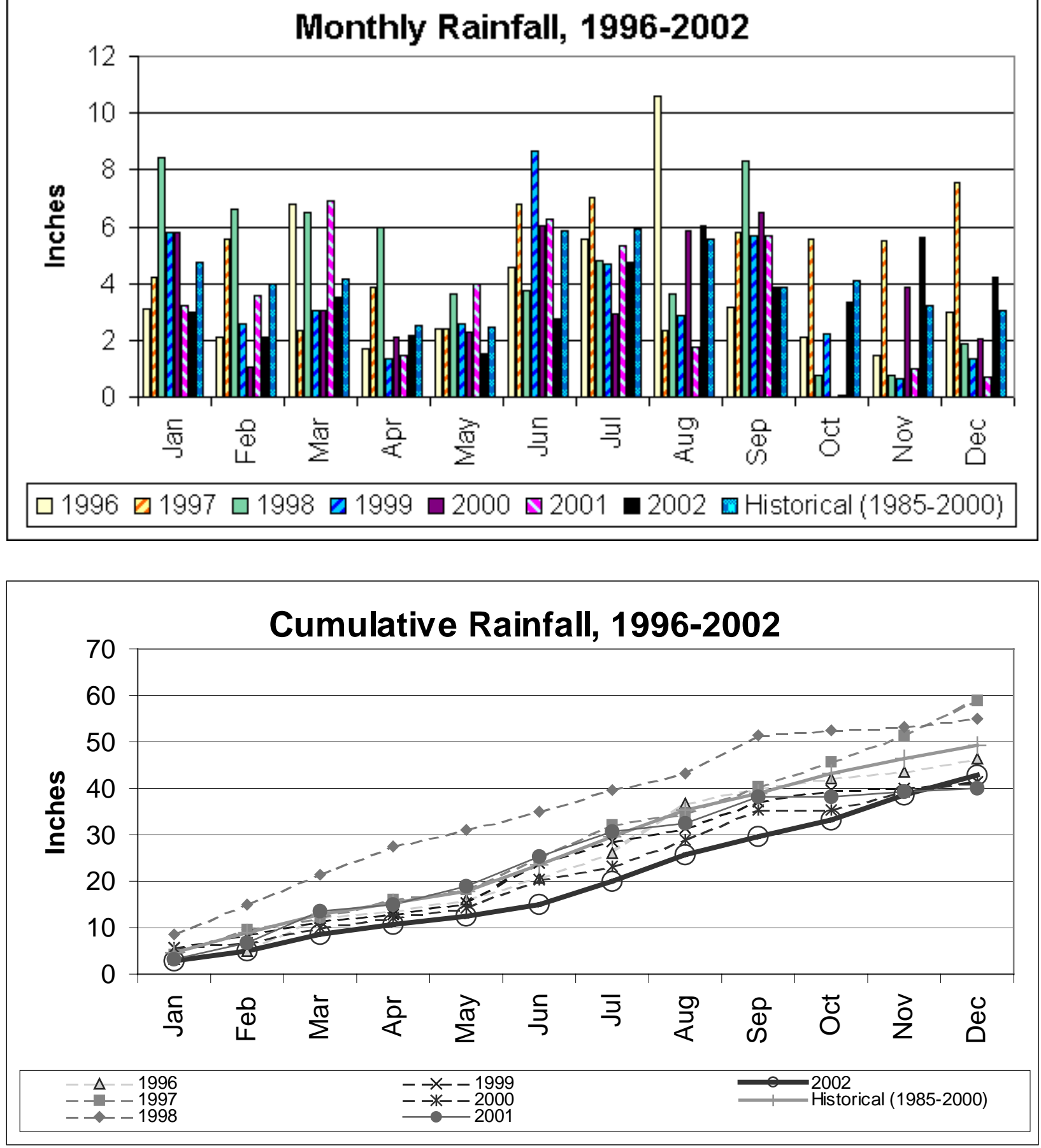

Figure 5 Monthly and cumulative rainfall (inches) in F Area, 1996 to 2002 

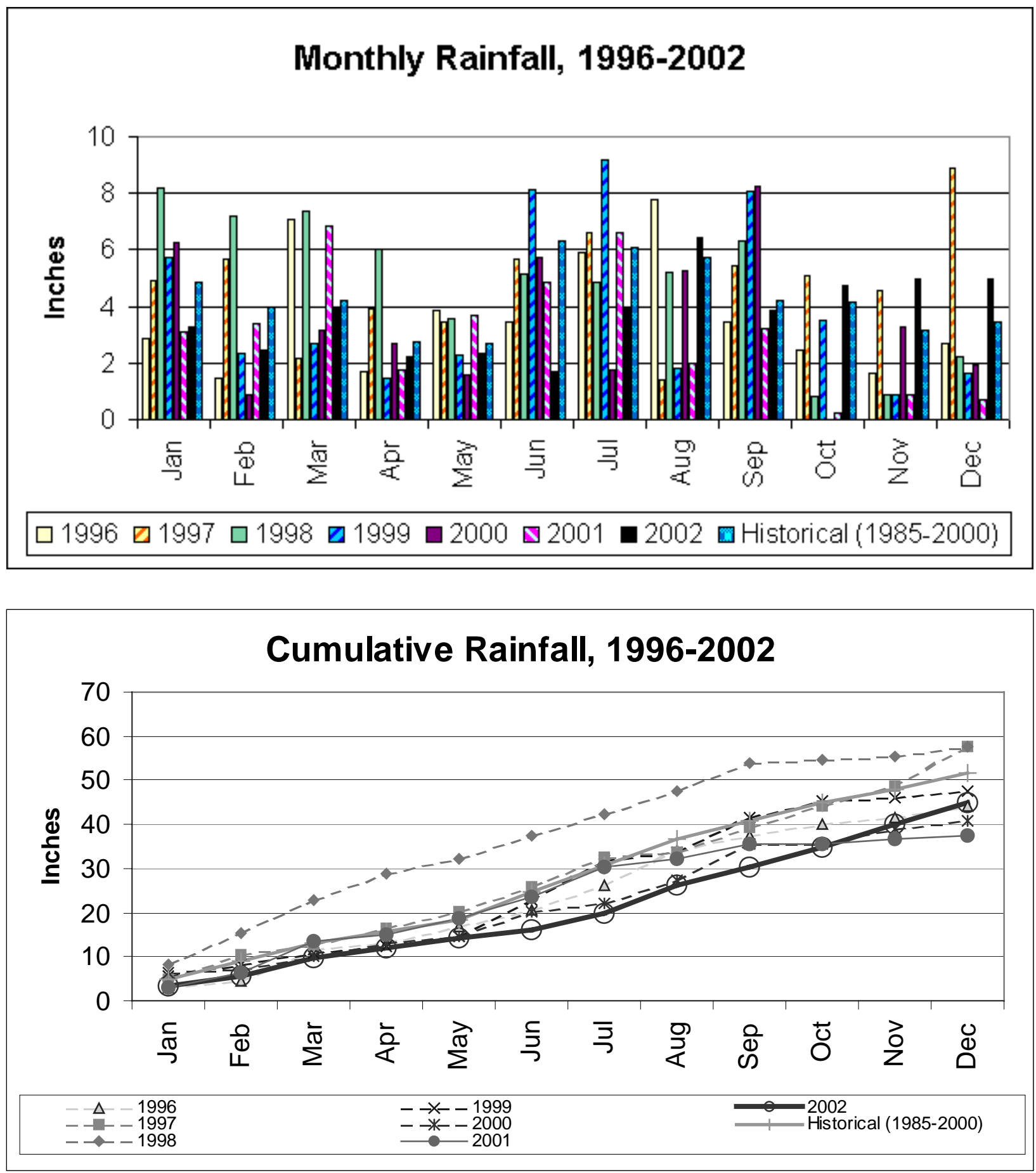

Figure 6 Monthly and cumulative rainfall (inches) in H Area, 1996 to 2002 


\section{FSP249A \& B}

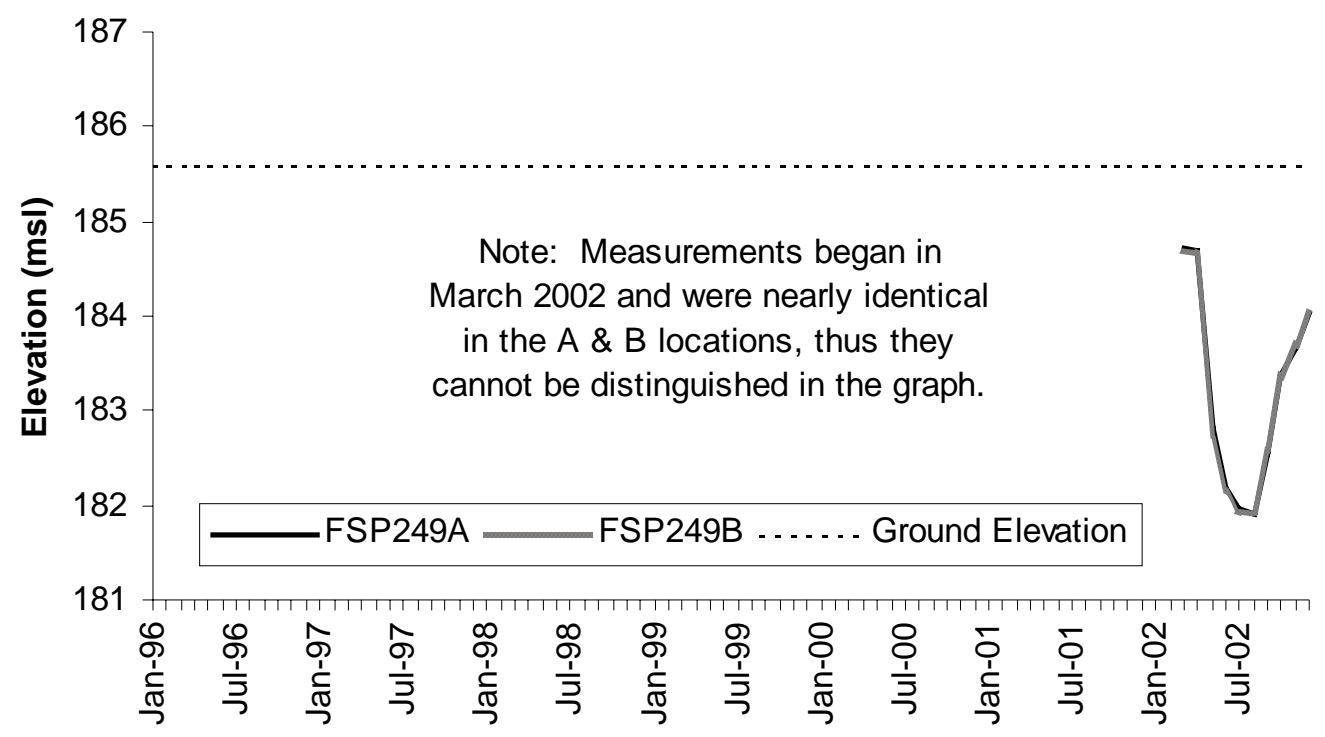

Figure 7 Monthly hydraulic head elevations (ft, msl) at FSP249A and FSP249B, through December 2002

FPZ001A

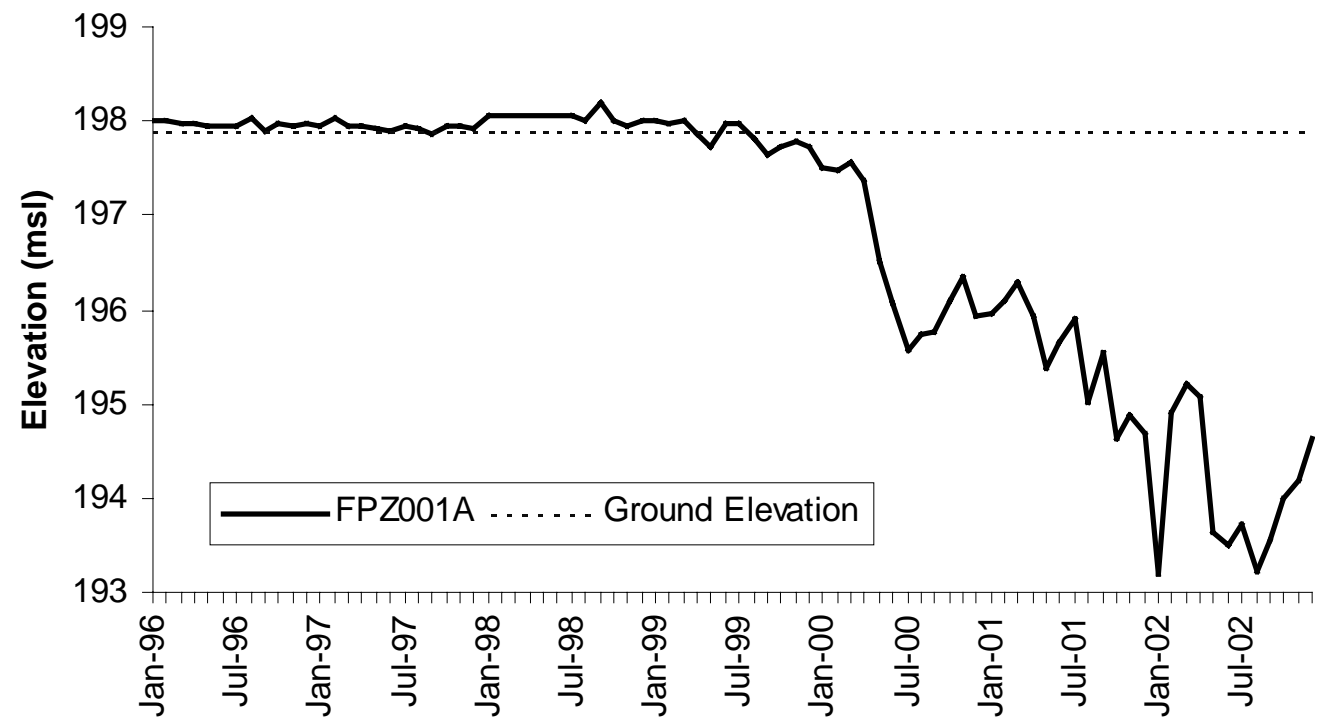

Figure 8 Monthly hydraulic head elevations (ft, msl) at FPZ001A, January 1996 to December 2002 
FPZO02A

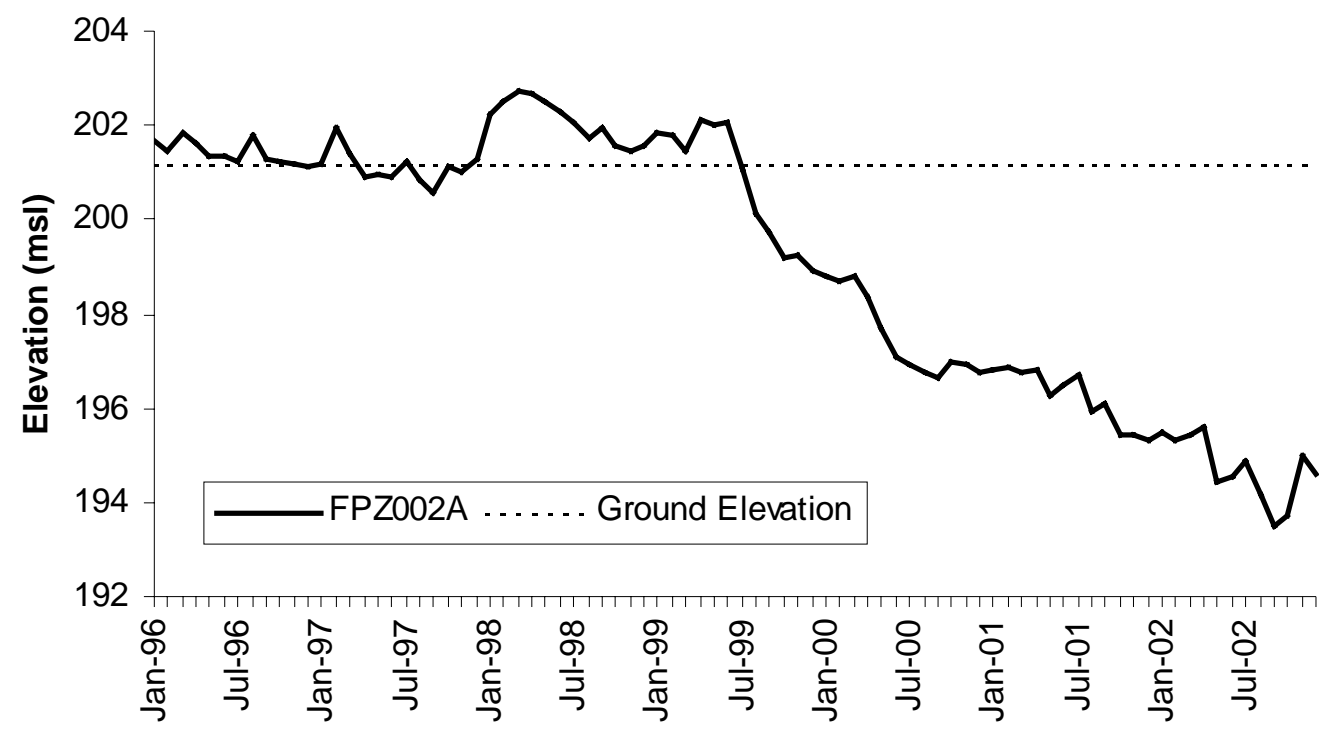

Figure 9 Monthly hydraulic head elevations (ft, msl) at FPZ002A, January 1996 to December 2002 
FPZ003A

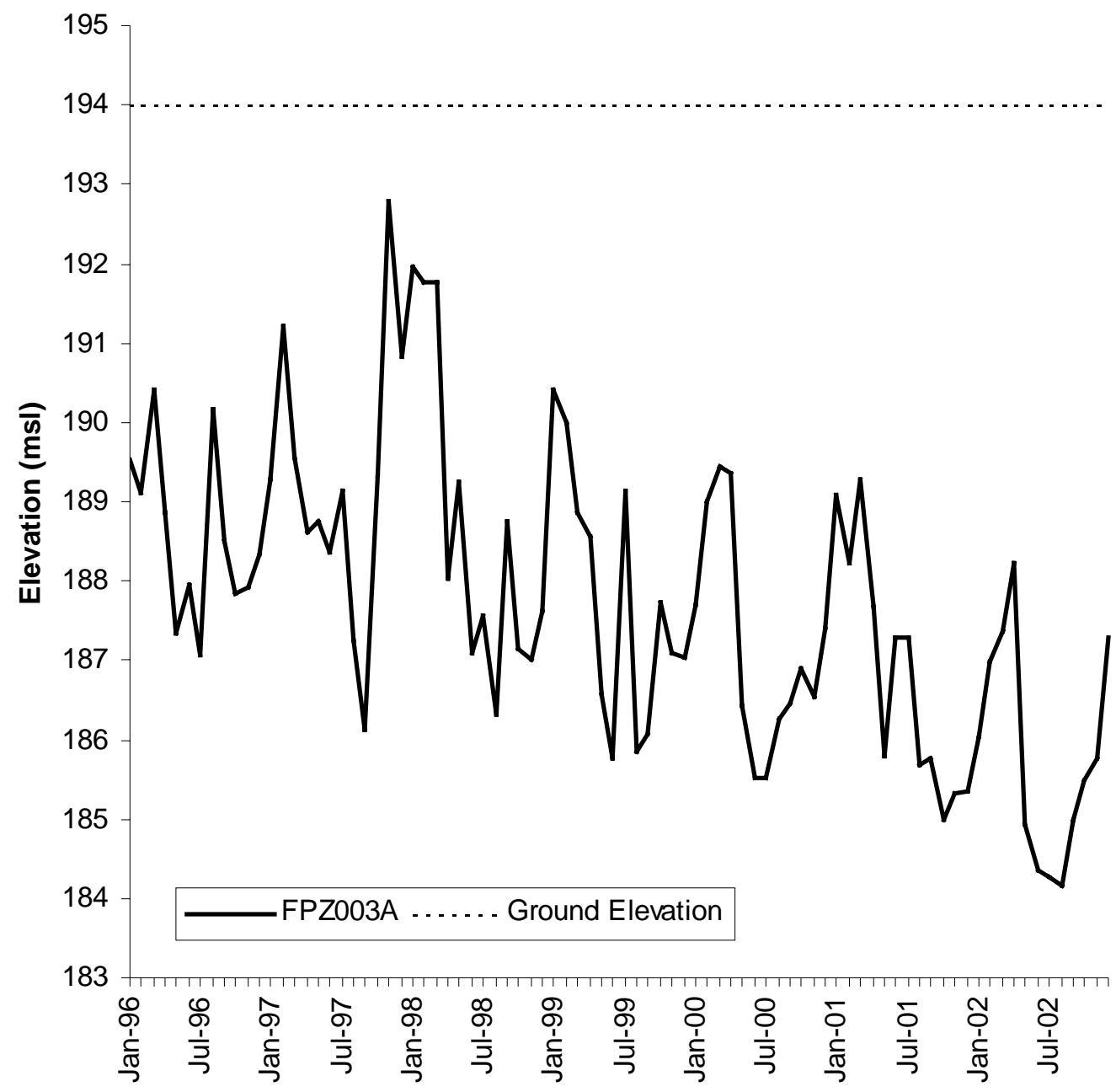

Figure 10 Monthly hydraulic head elevations (ft, msl) at FPZ003A, January 1996 to December 2002 


\section{FSP002A \& B}

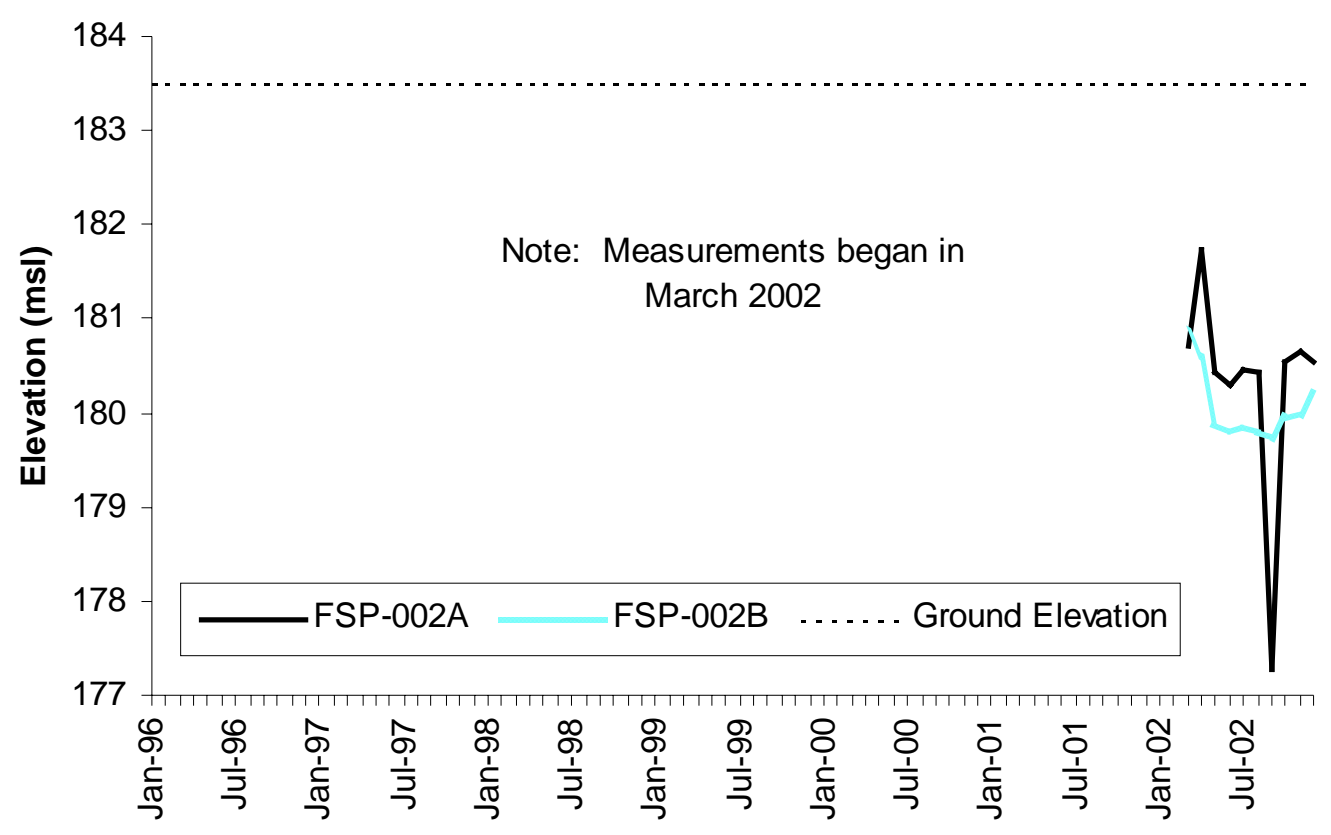

Figure 11 Monthly hydraulic head elevations (ft, msl) at FSP002A and FSP002B through December 2002

\section{FPZ004A}

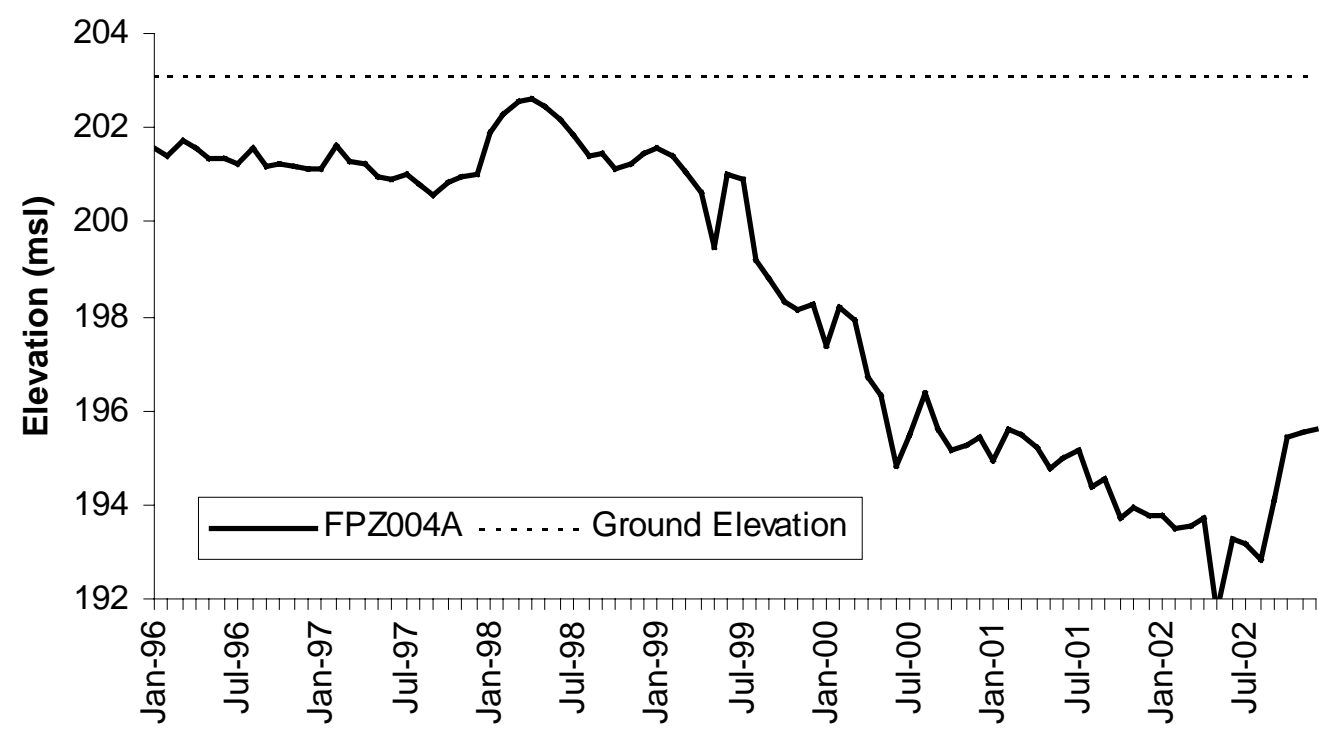

Figure 12 Monthly hydraulic head elevations (ft, msl) at FPZ004A, January 1996 to December 2002 
FPZ005A \& B

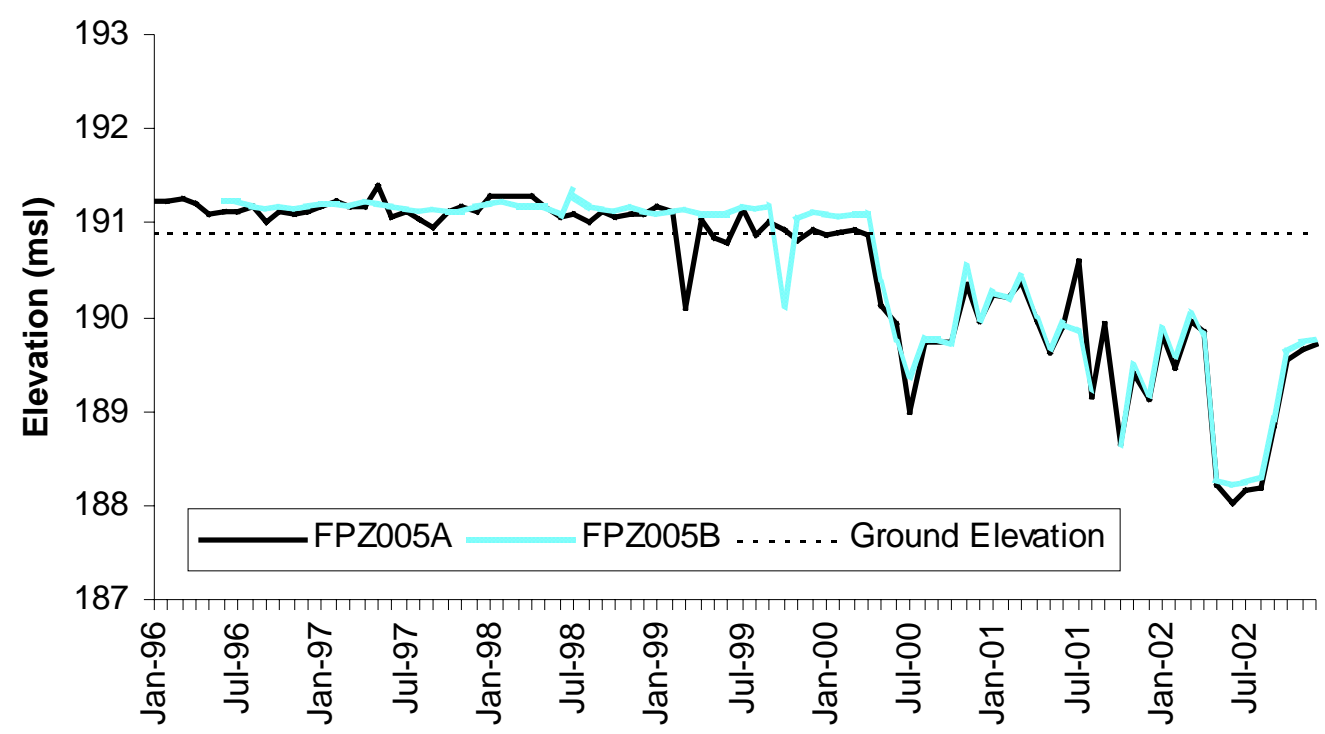

Figure 13 Monthly hydraulic head elevations (ft, msl) at FPZ005A and FPZ005B, January 1996 to December 2002

FPZ006A \& B

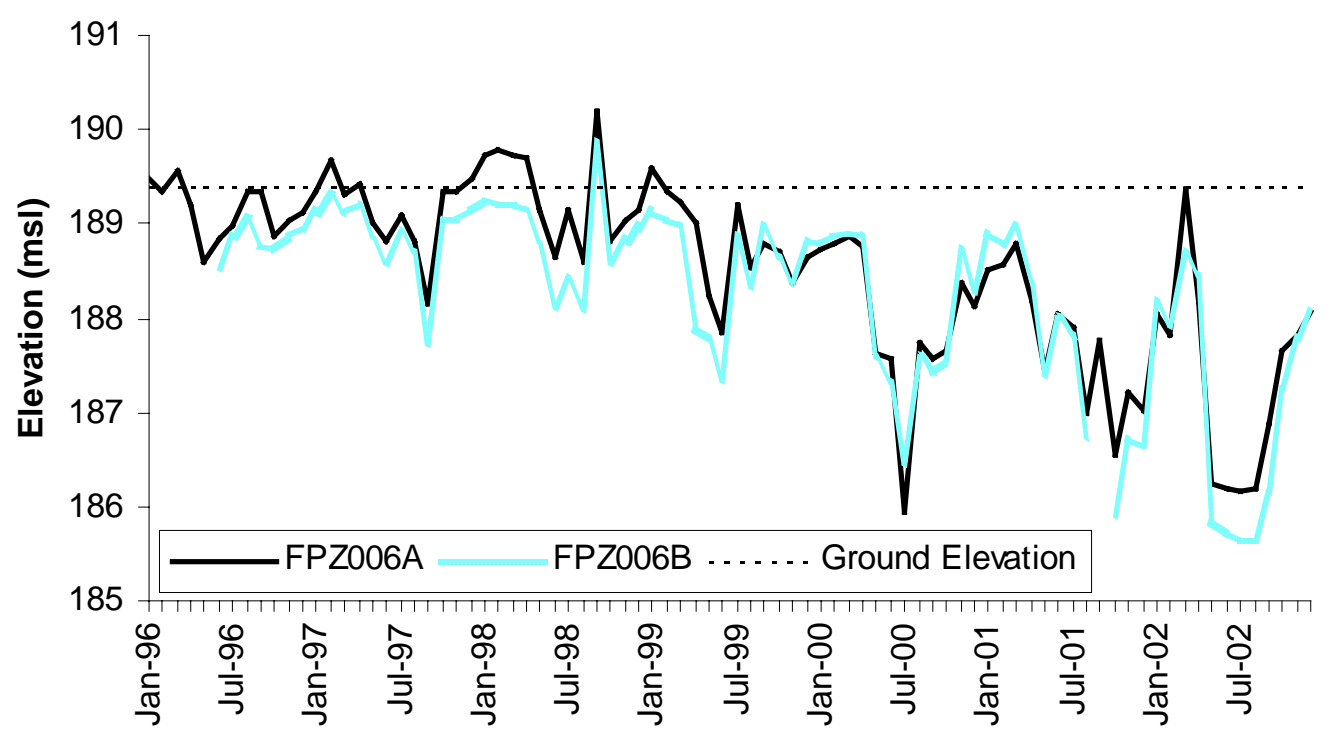

Figure 14 Monthly hydraulic head elevations (ft, msl) at FPZ006A and FPZ006B, January 1996 to December 2002 


\section{FPZ007A \& B}

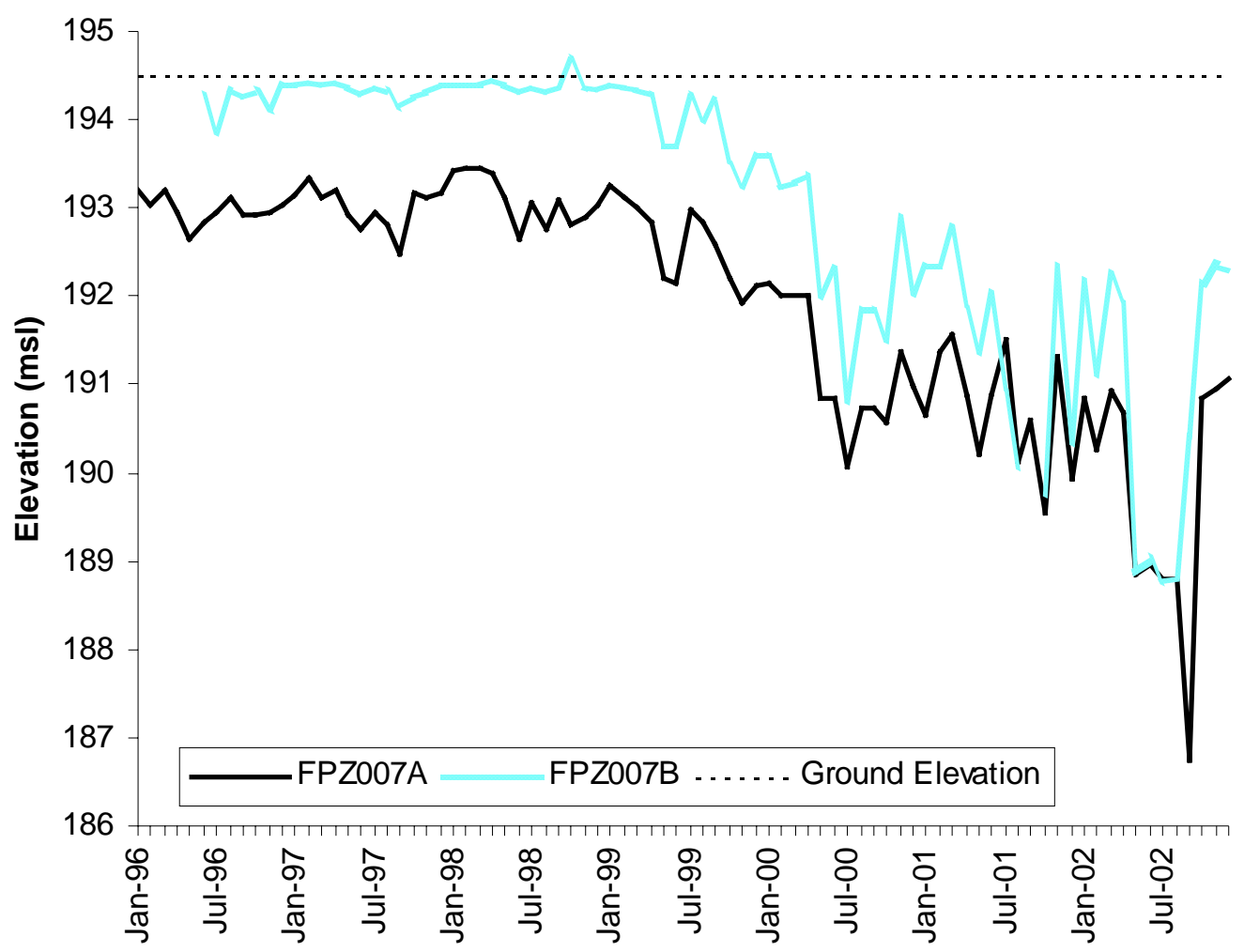

Figure 15 Monthly hydraulic head elevations (ft, msl) at FPZ007A and FPZ007B, January 1996 to December 2002

FPZ008A \& B

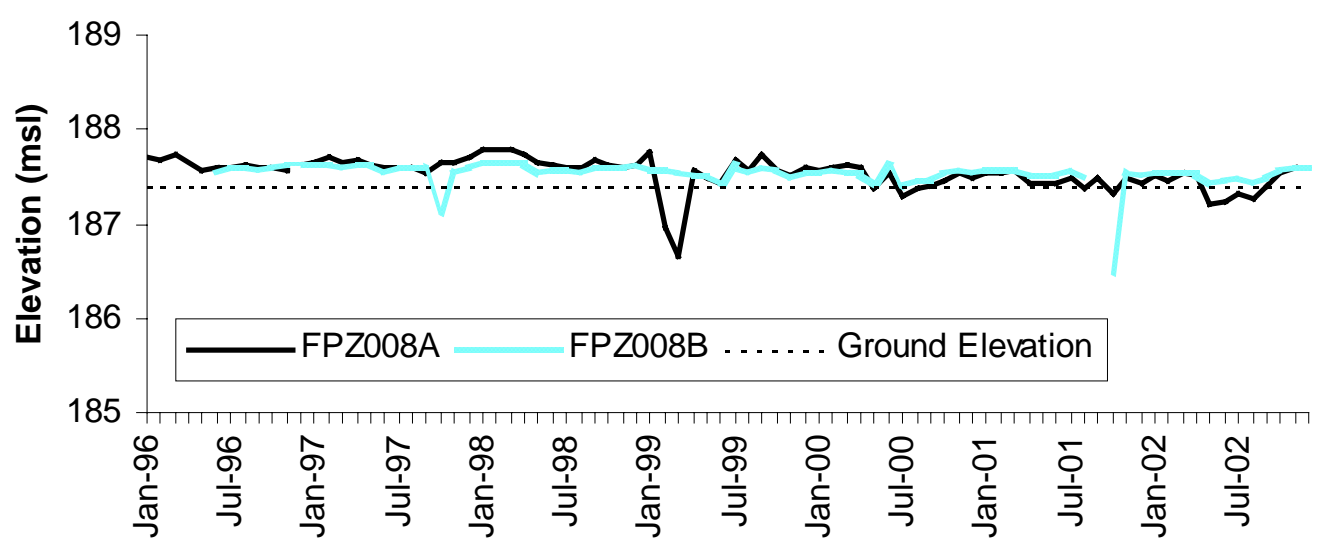

Figure 16 Monthly hydraulic head elevations (ft, msl) at FPZ008A and FPZ008B, January 1996 to December 2002 


\section{HPSP076A \& B}

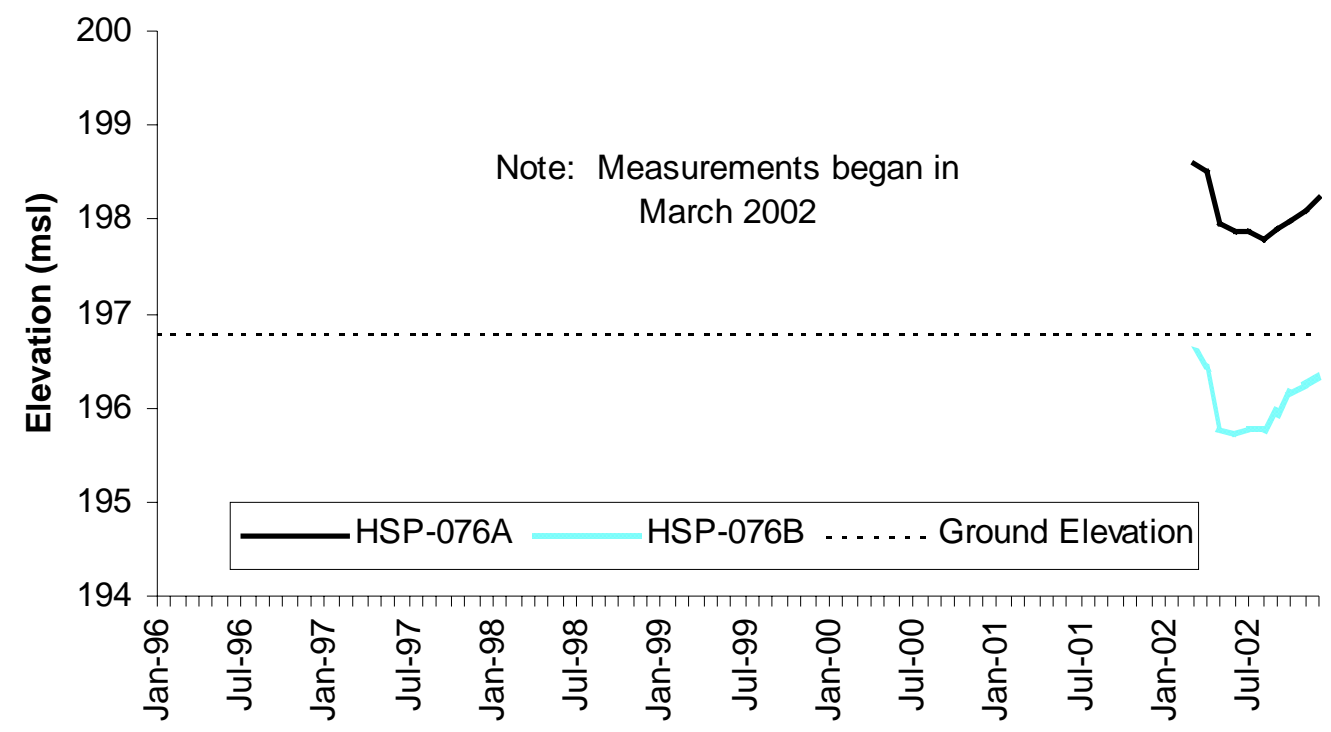

Figure 17 Monthly hydraulic head elevations (ft, msl) at HSP076A \& HSP076B， through December 2002

\section{HPSP060A \& B}

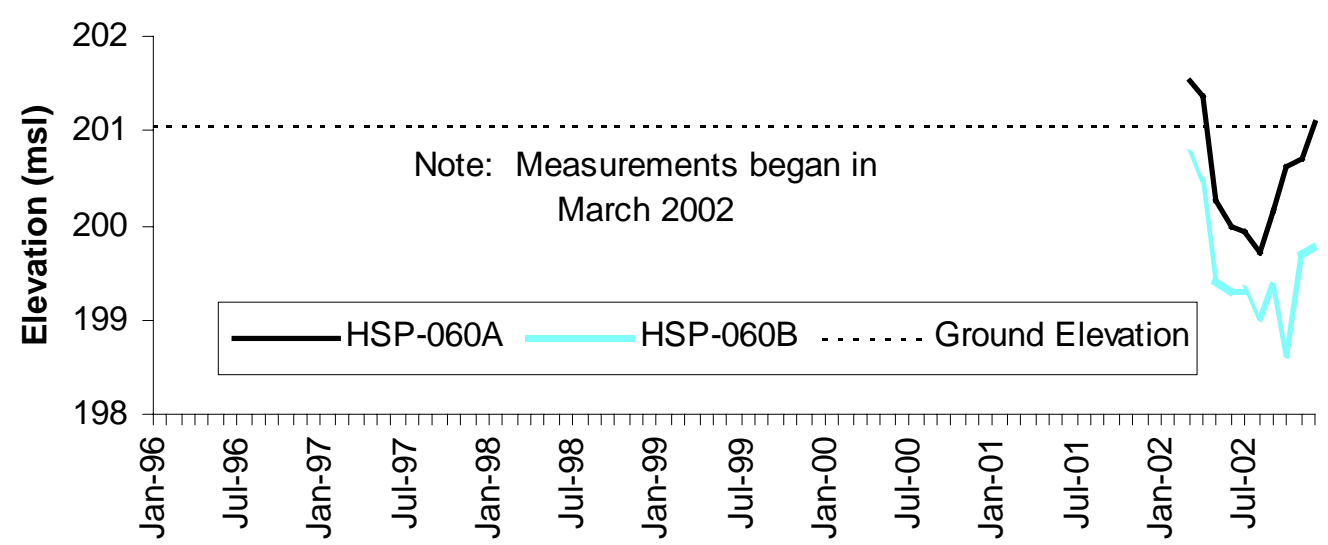

Figure 18 Monthly hydraulic head elevations (ft, msl) at HSP060A and HSP060B, through December 2002 


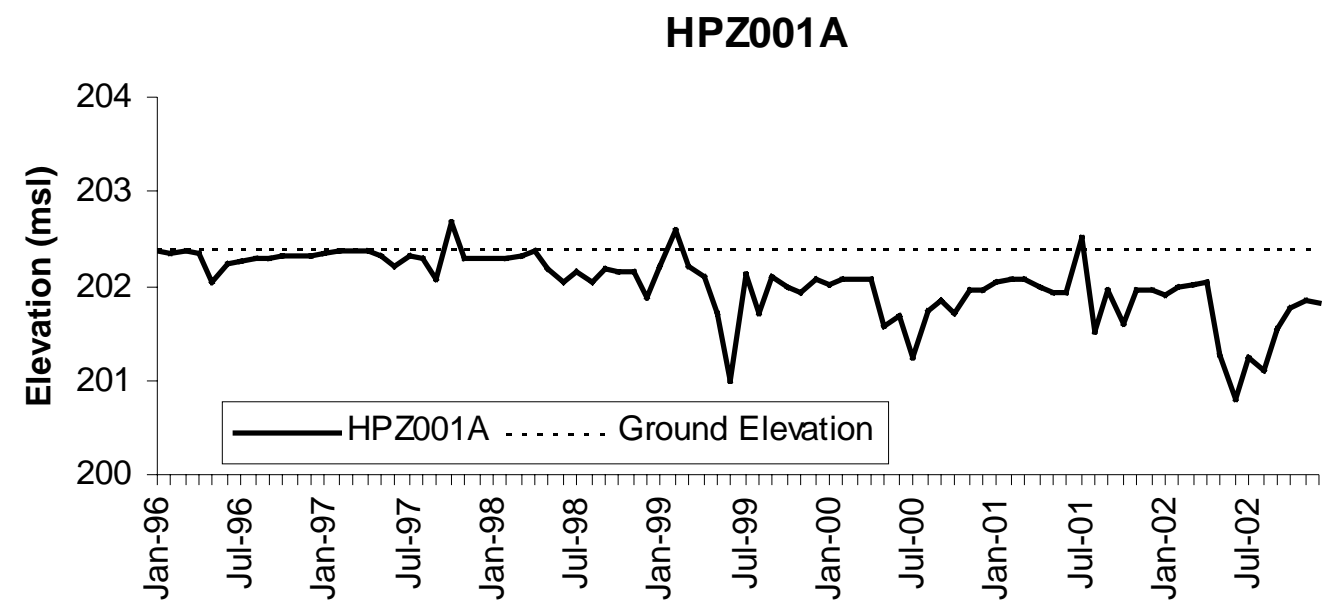

Figure 19 Monthly hydraulic head elevations (ft, msl) at HPZ001A, January 1996 to December 2002

HPZ002A

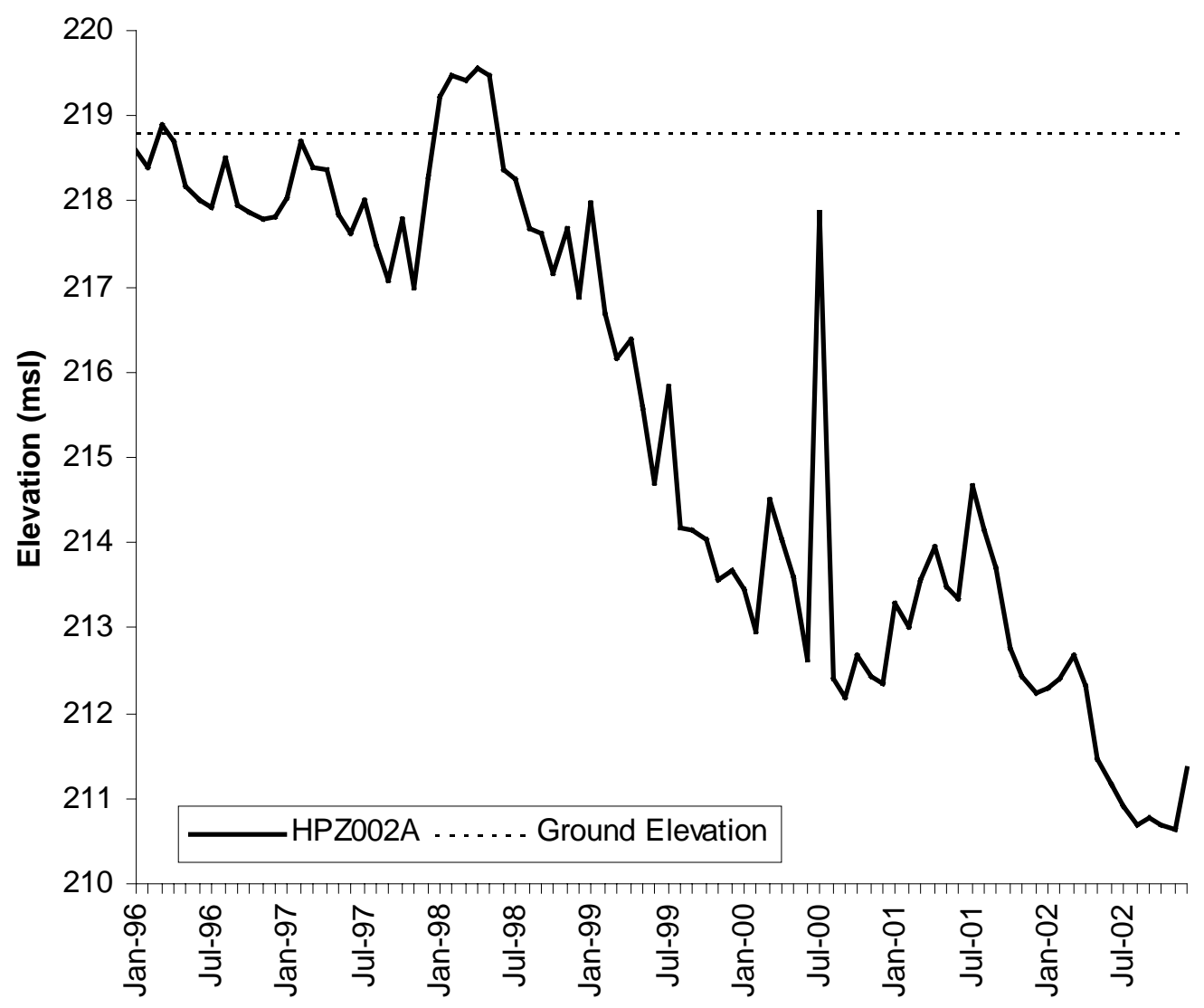

Figure 20 Monthly hydraulic head elevations (ft, msl) at HPZ002A, January 1996 to December 2002 


\section{HPZO03A \& B}

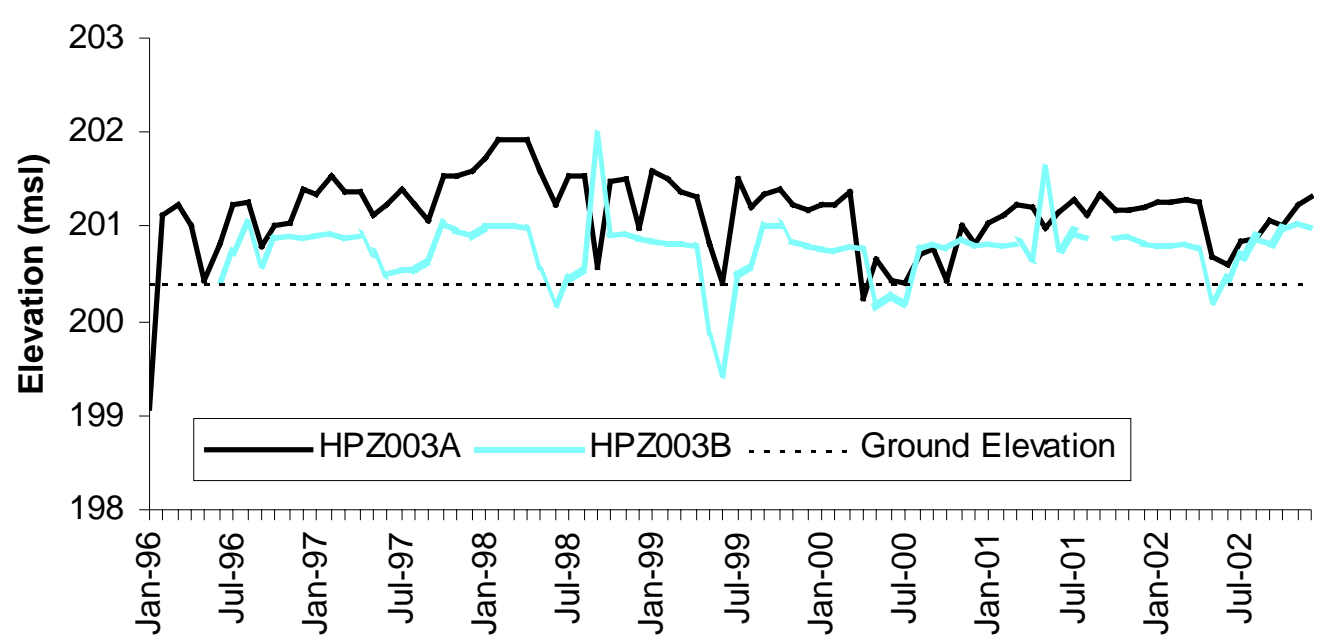

Figure 21 Monthly hydraulic head elevations (ft, msl) at HPZ003A and HPZ003B, January 1996 to December 2002

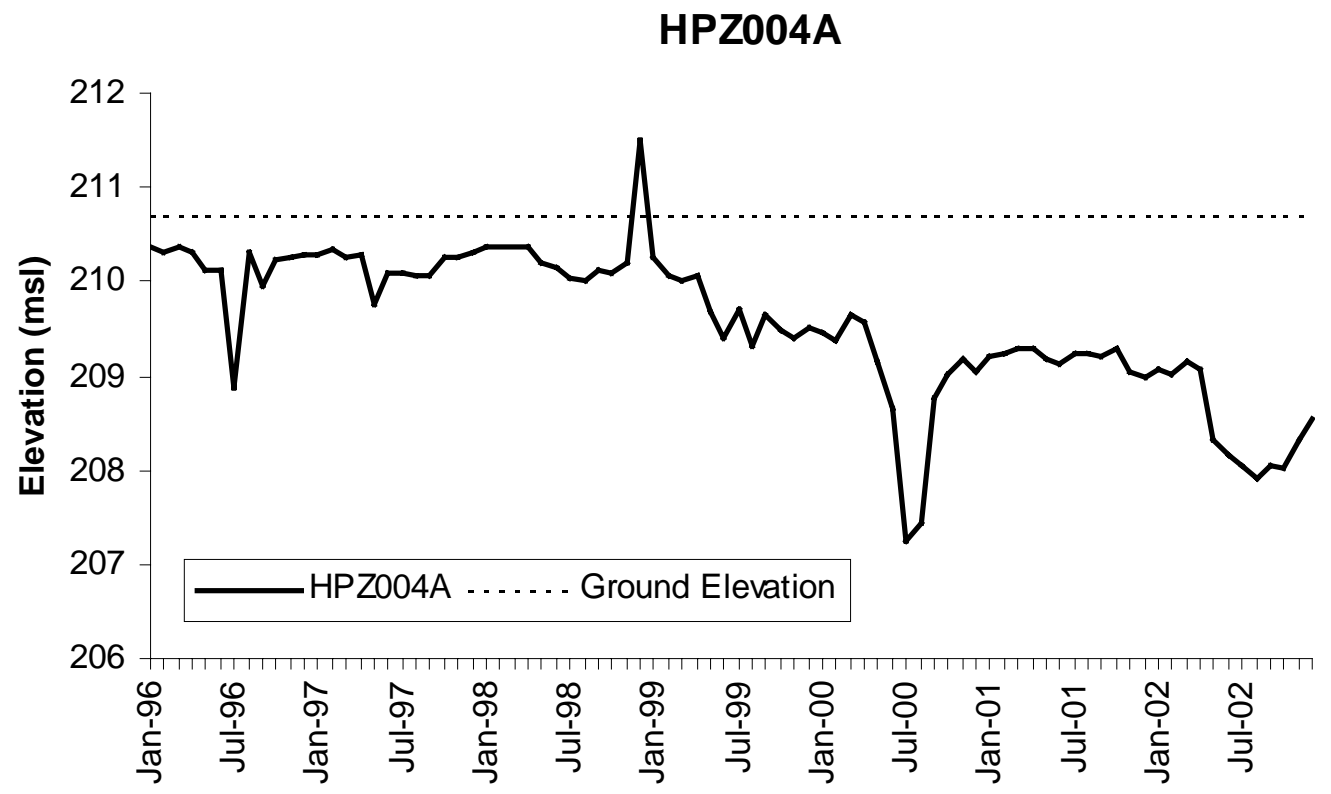

Figure 22 Monthly hydraulic head elevations (ft, msl) at HPZ004A, January 1996 to December 2002 


\section{HPZO05A \& B}

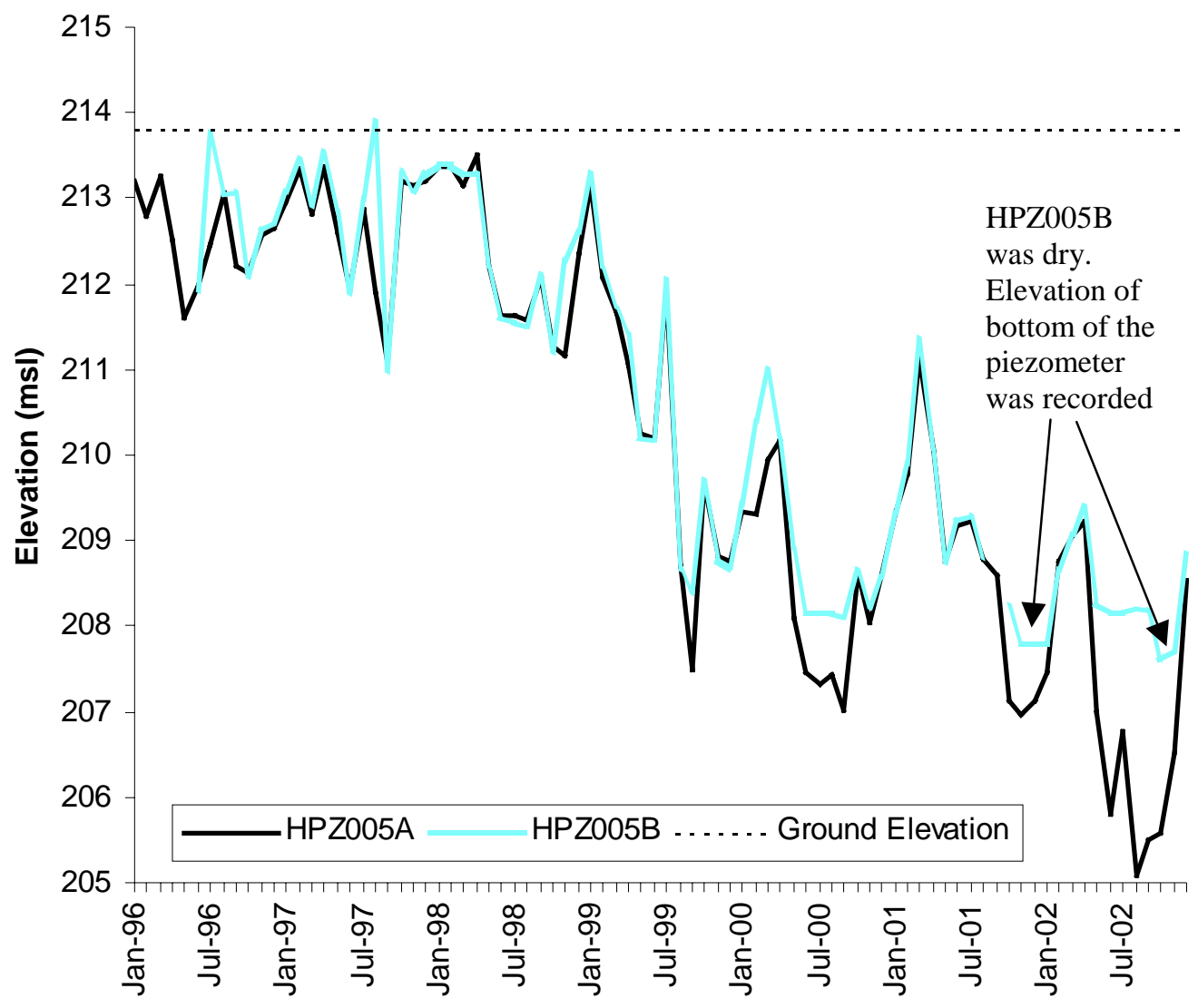

Figure 23 Monthly hydraulic head elevations at HPZ005A and HPZ005B (ft, msl), January 1996 to December 2002 


\section{HPZ006A}

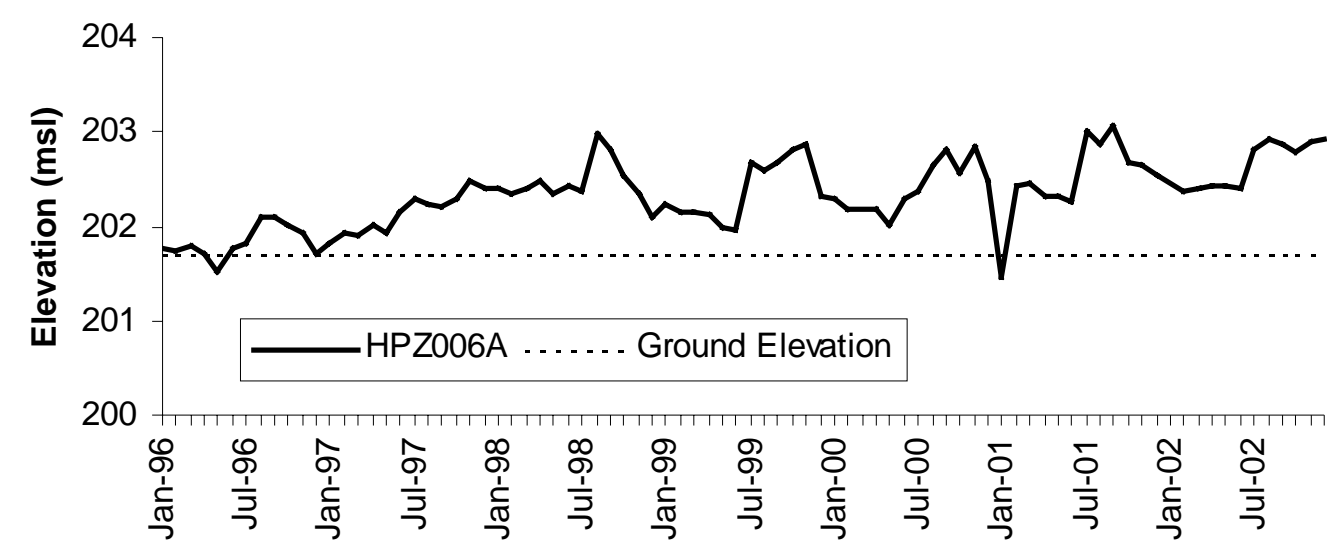

Figure 24 Monthly hydraulic head elevations (ft, msl) at HPZ006A, January 1996 to December 2002

FHR001

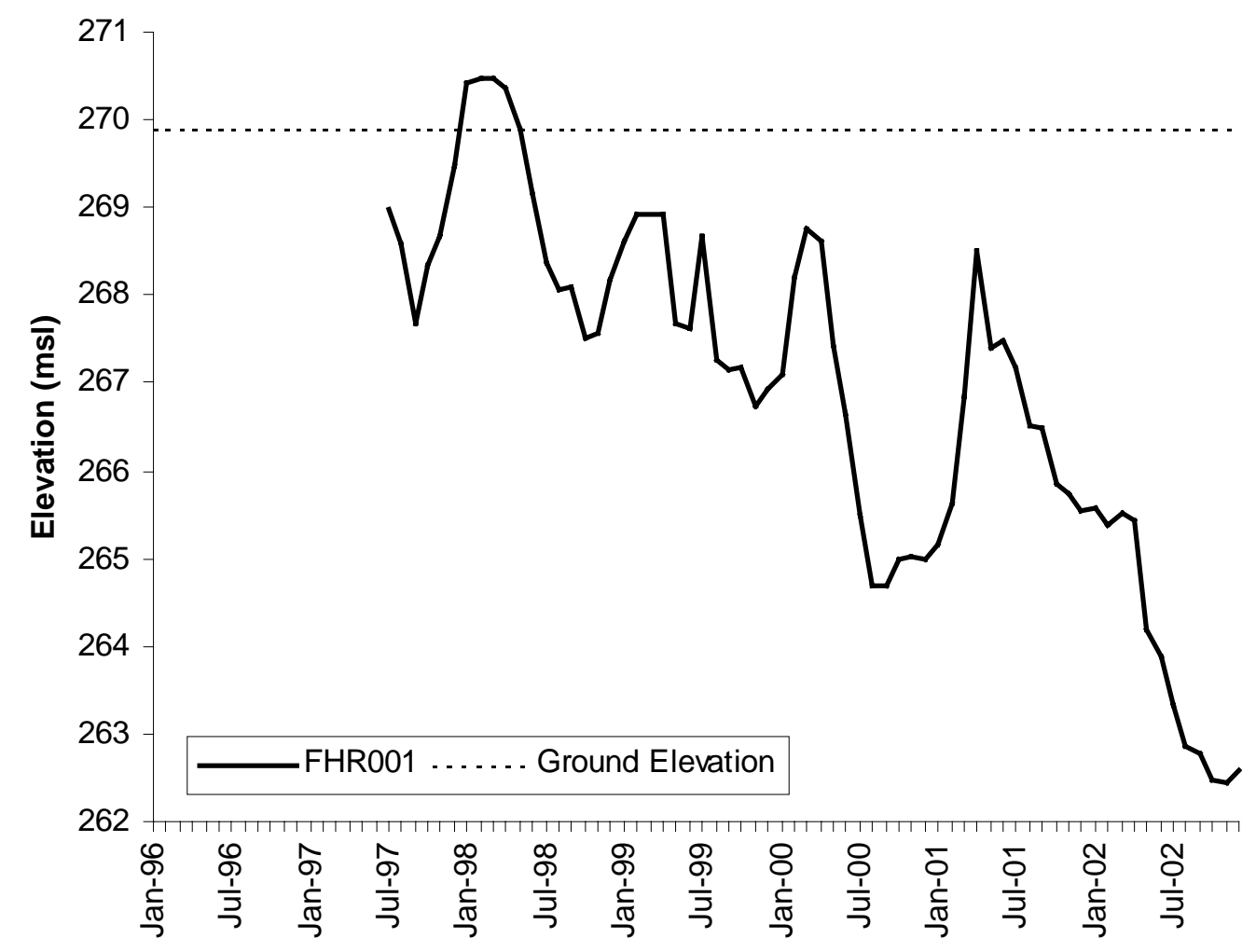

Figure 25 Monthly hydraulic head elevations (ft, msl) at FHR001, July 1997 to December 2002 


\section{FHR002}

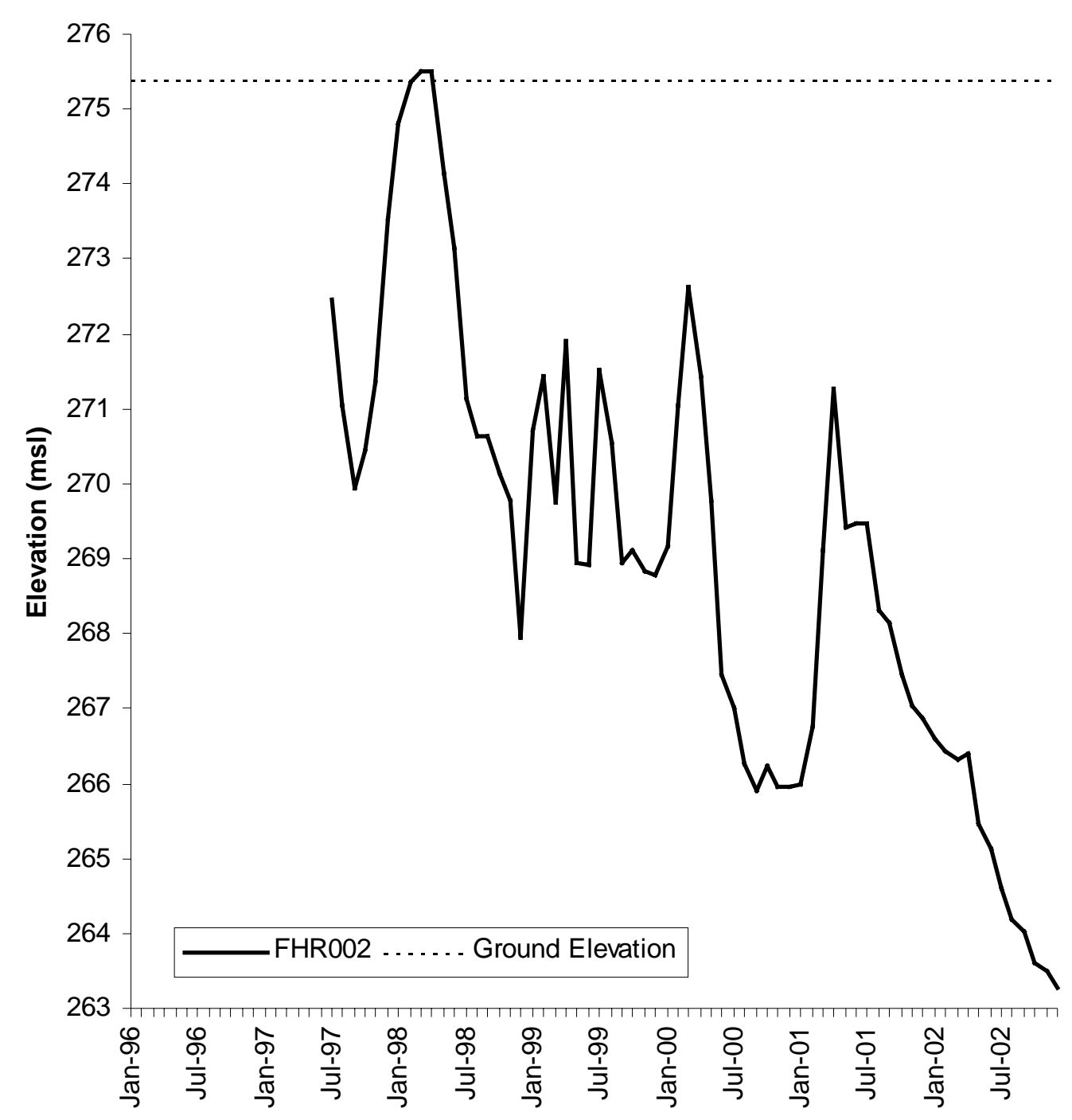

Figure 26 Monthly hydraulic head elevations (ft, msl) at FHR002, July 1997 to December 2002 


\section{FHR003}

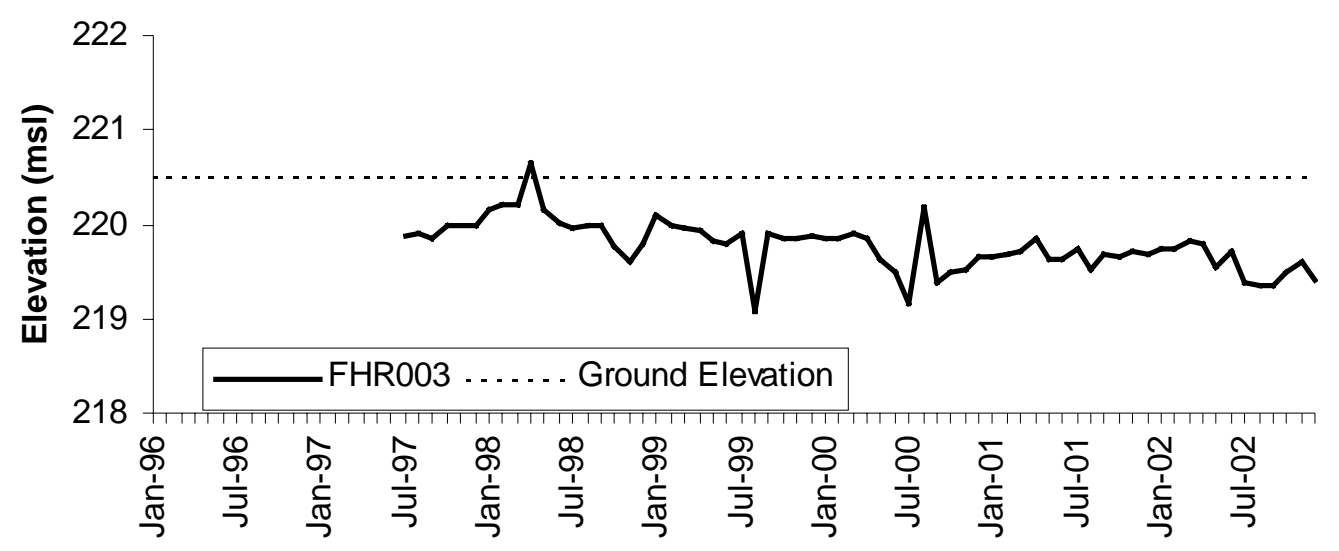

Figure 27 Monthly hydraulic head elevations (ft, msl) at FHR003, July 1997 to December 2002

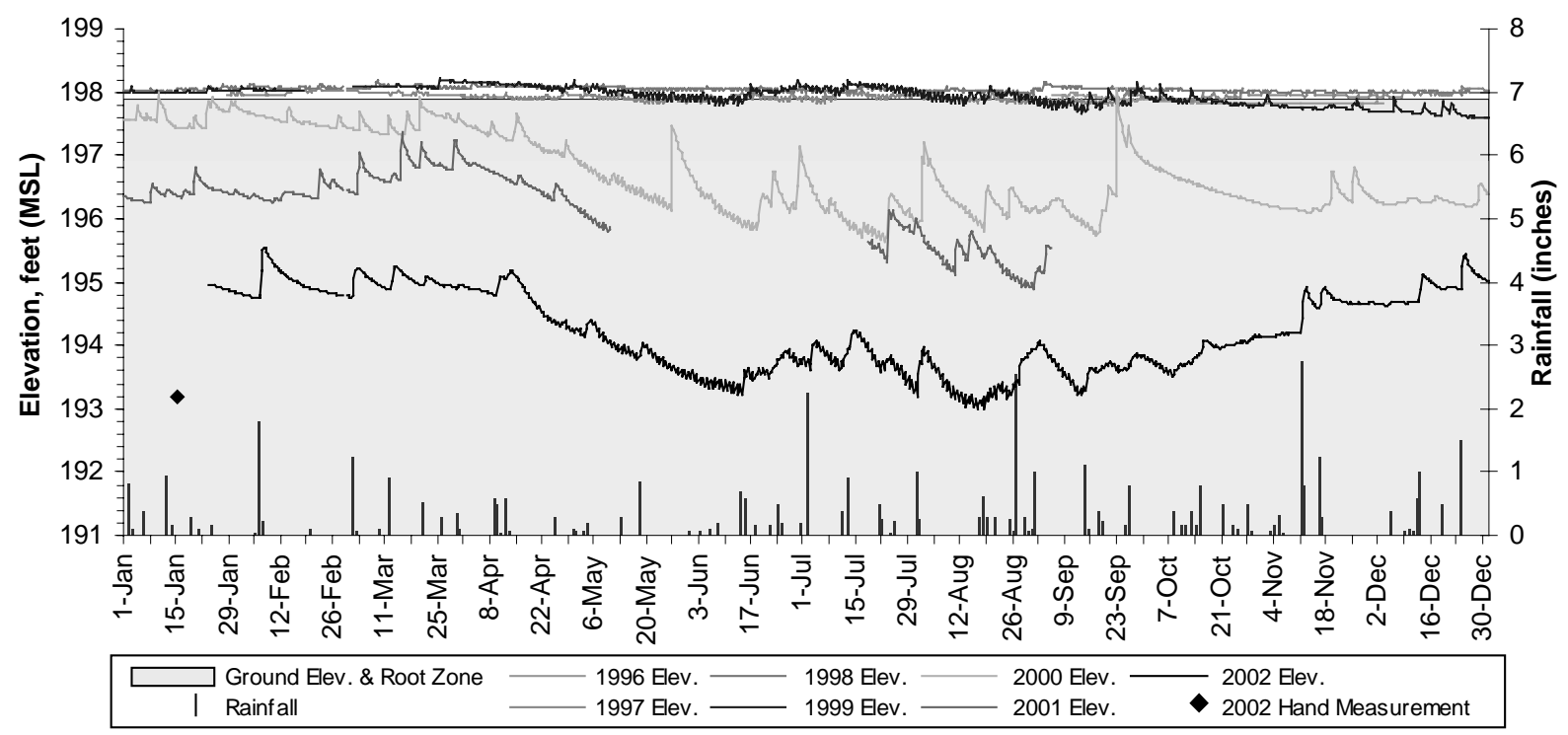

Figure 28 Comparison of hydraulic head elevation and rainfall at FPZ001A (F Area) in 2002 


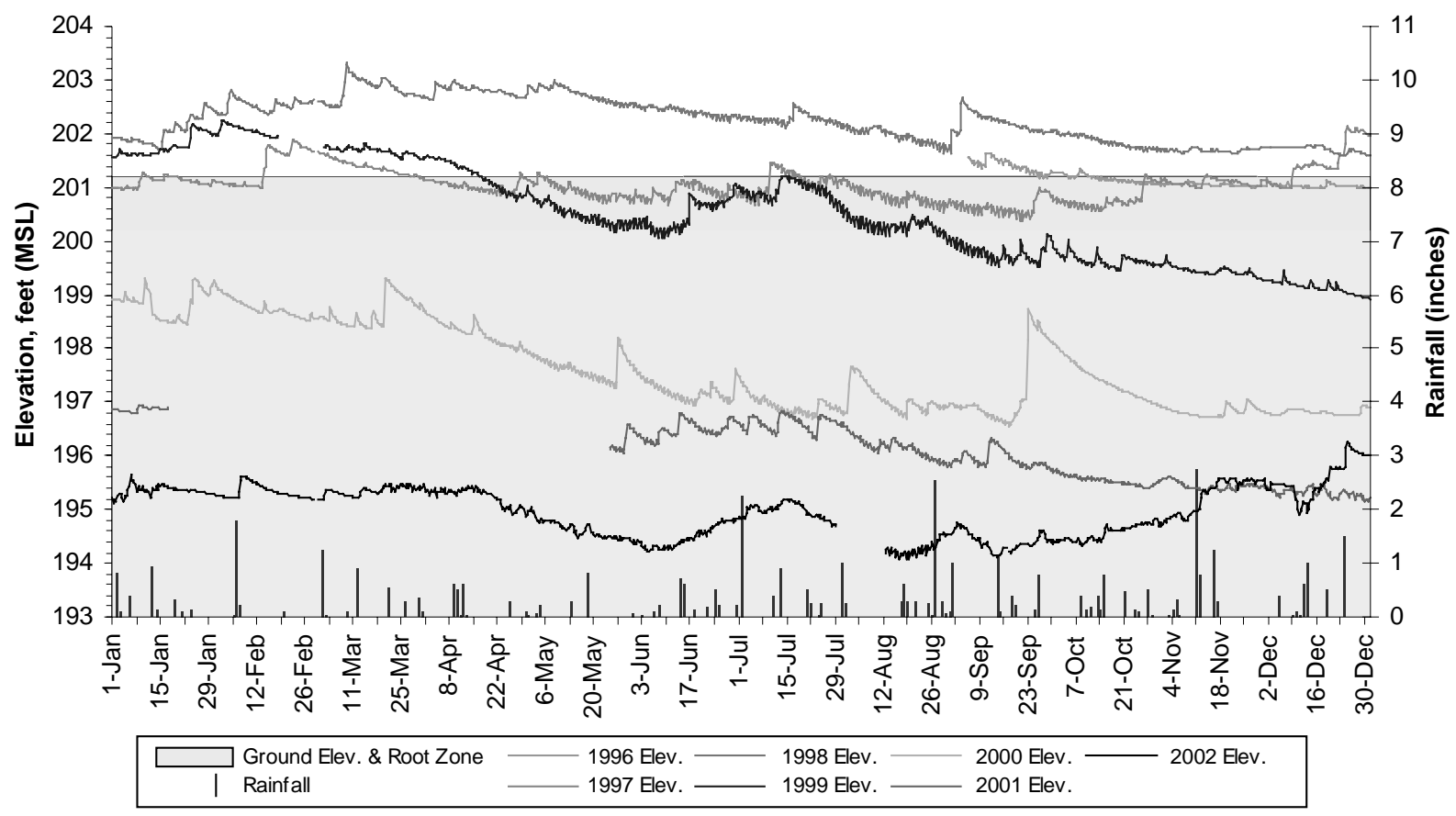

Figure 29 Comparison of hydraulic head elevation and rainfall at FPZ002A (F Area) in 2002

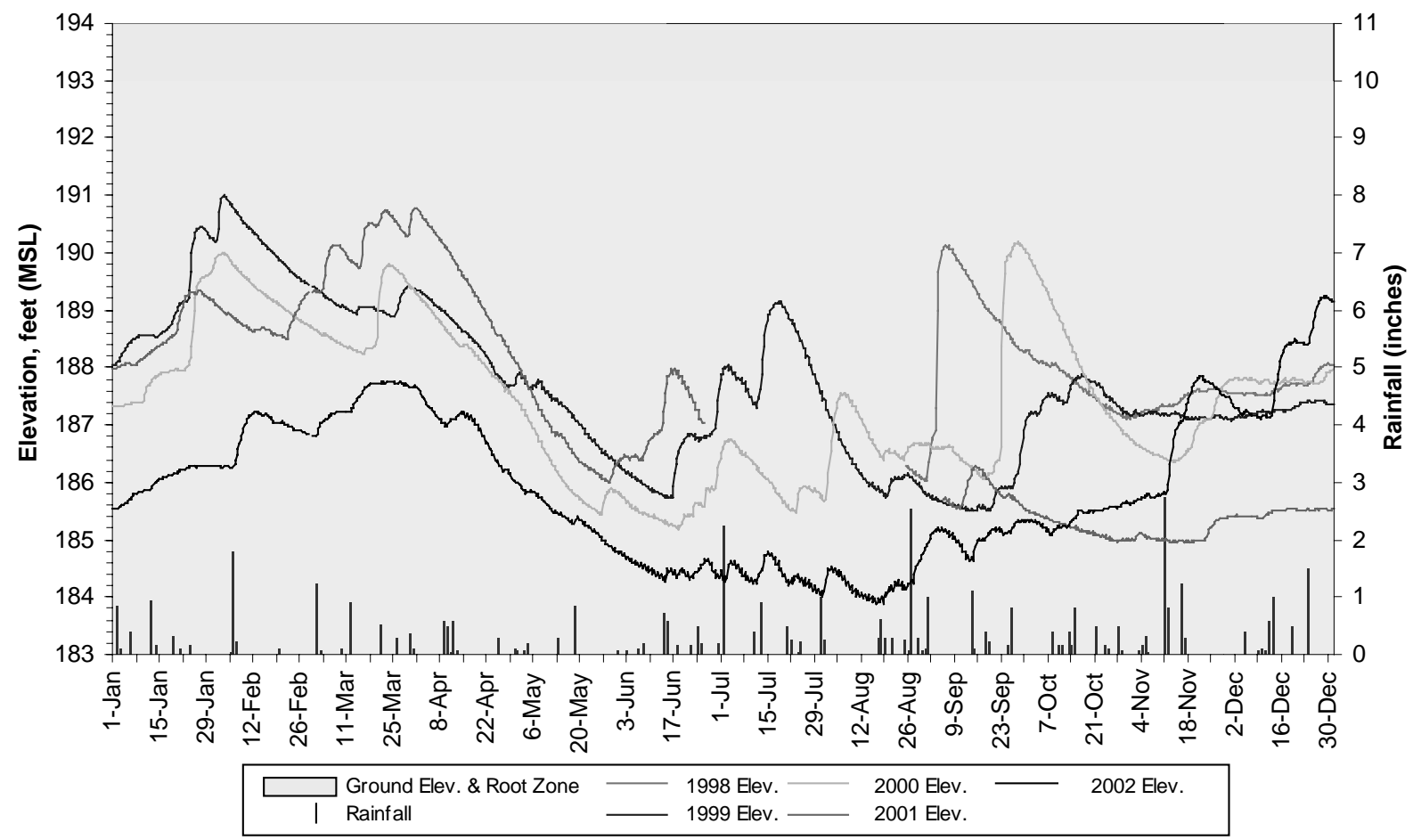

Figure 30 Comparison of hydraulic head elevation and rainfall at FPZ003A (F Area) in 2002 


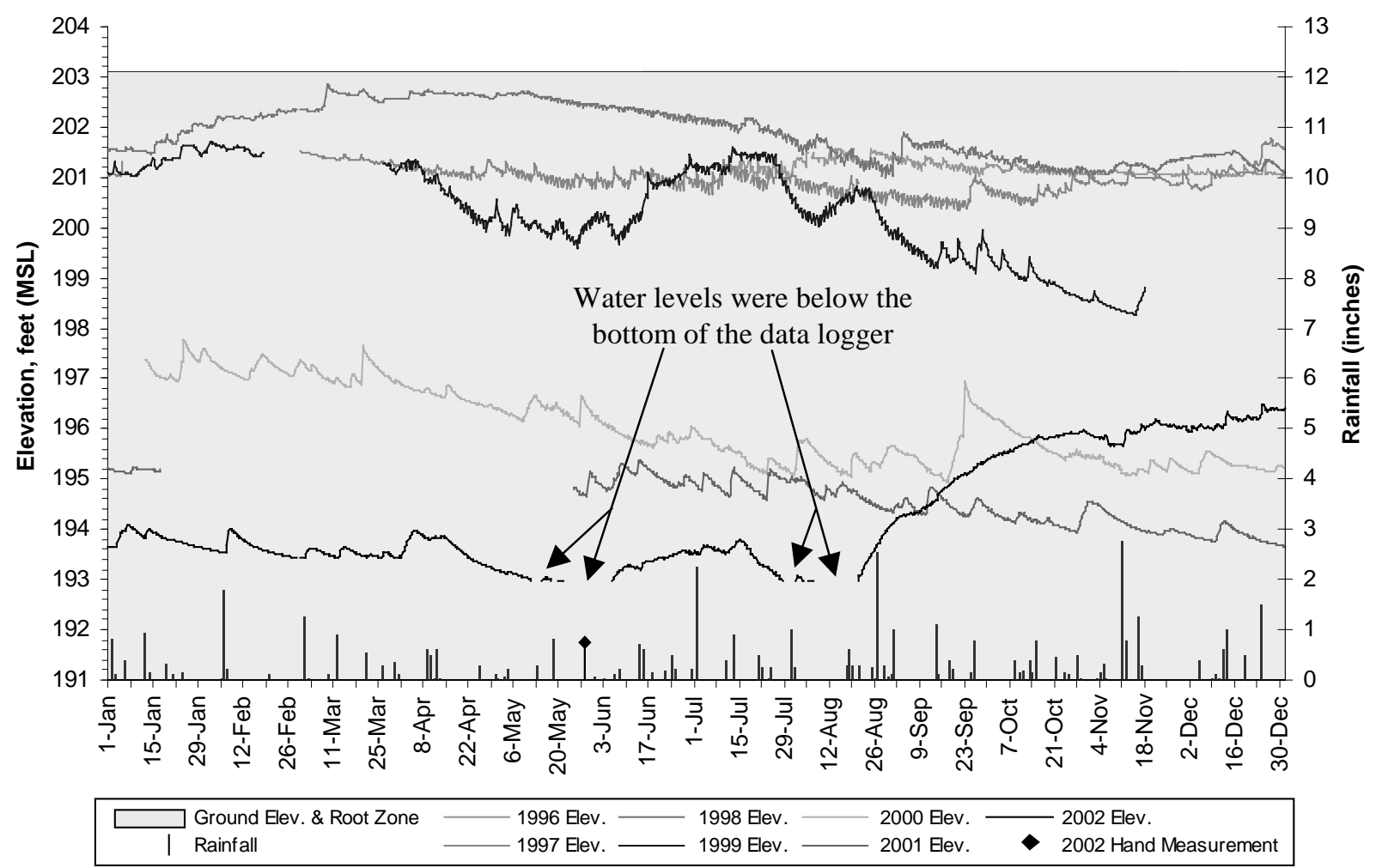

Figure 31 Comparison of hydraulic head elevation and rainfall at FPZ004A (F Area) in 2002

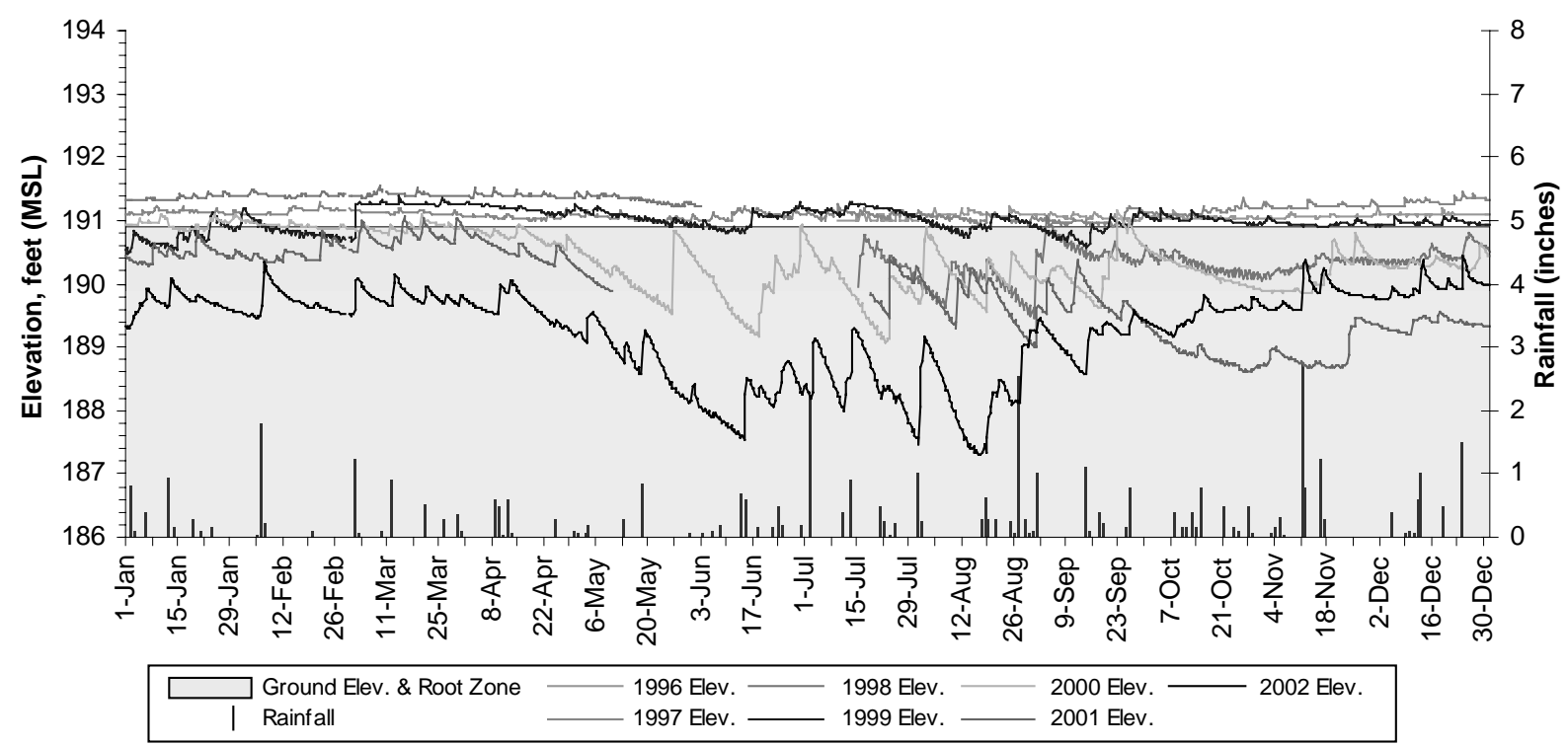

Figure 32 Comparison of hydraulic head elevation and rainfall at FPZ005A (F Area) in 2002 


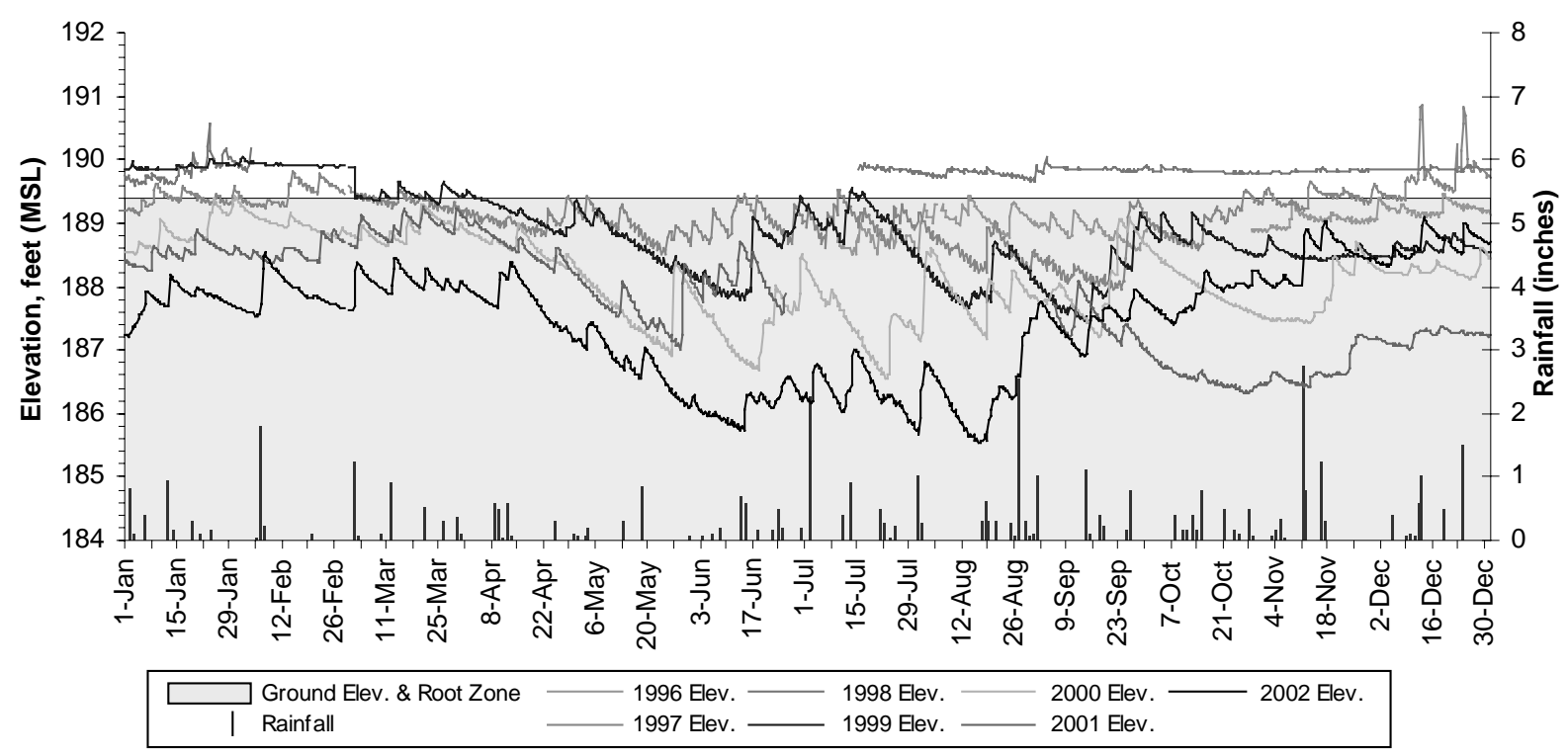

Figure 33 Comparison of hydraulic head elevation and rainfall at FPZ006A (F Area) in 2002

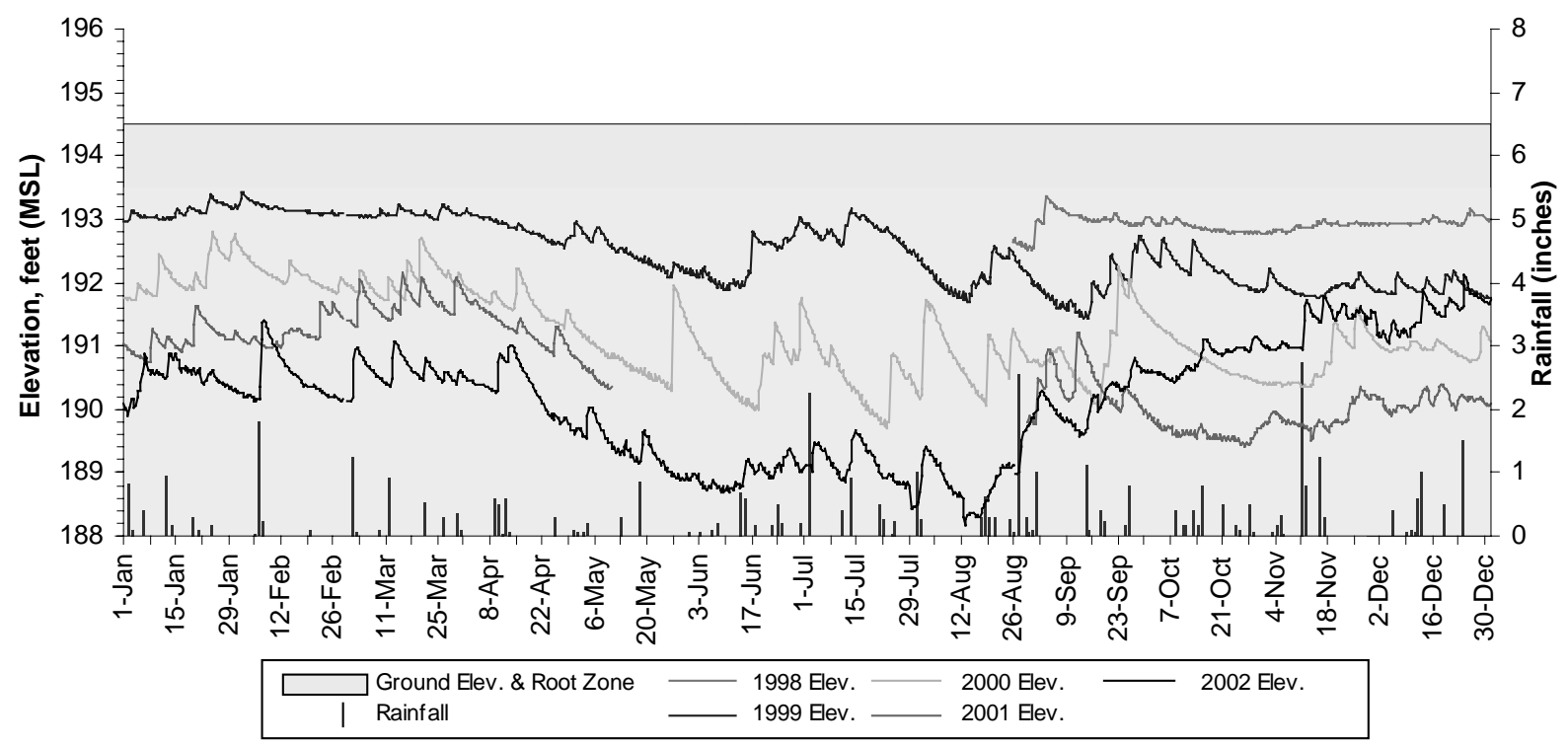

Figure 34 Comparison of hydraulic head elevation and rainfall at FPZ007A (F Area) in 2002 


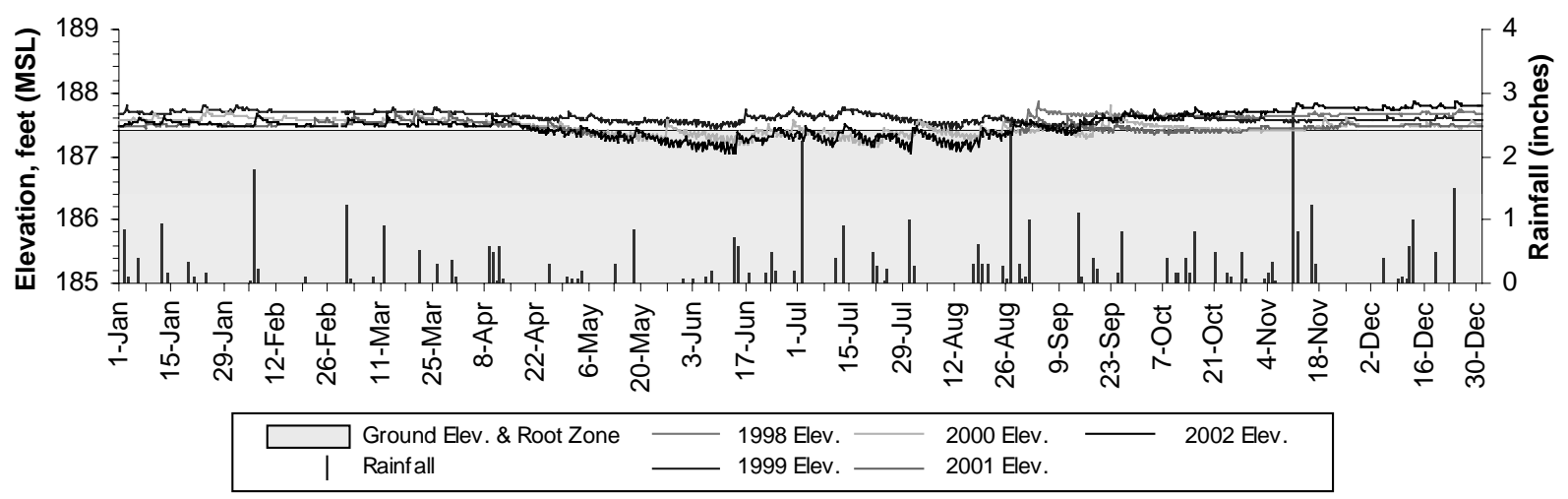

Figure 35 Comparison of hydraulic head elevation and rainfall at FPZ008A (F Area) in 2002

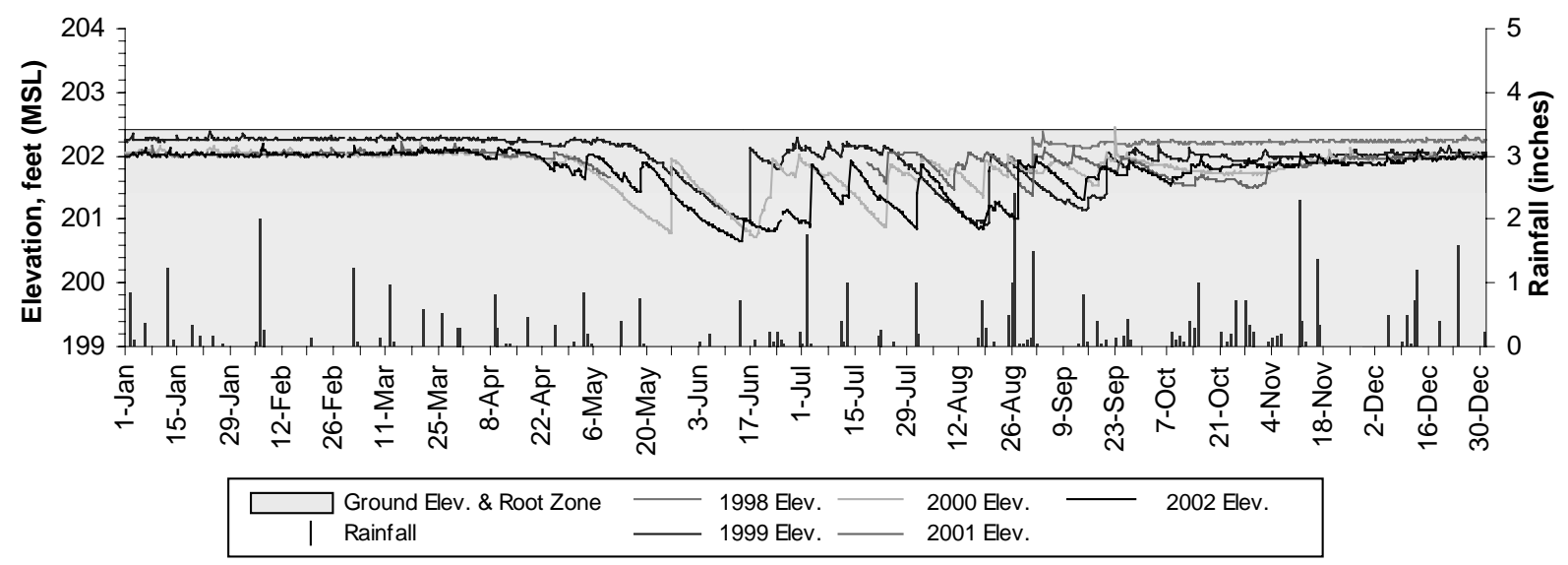

Figure 36 Comparison of hydraulic head elevation and rainfall at HPZ001A (H Area) in 2002 


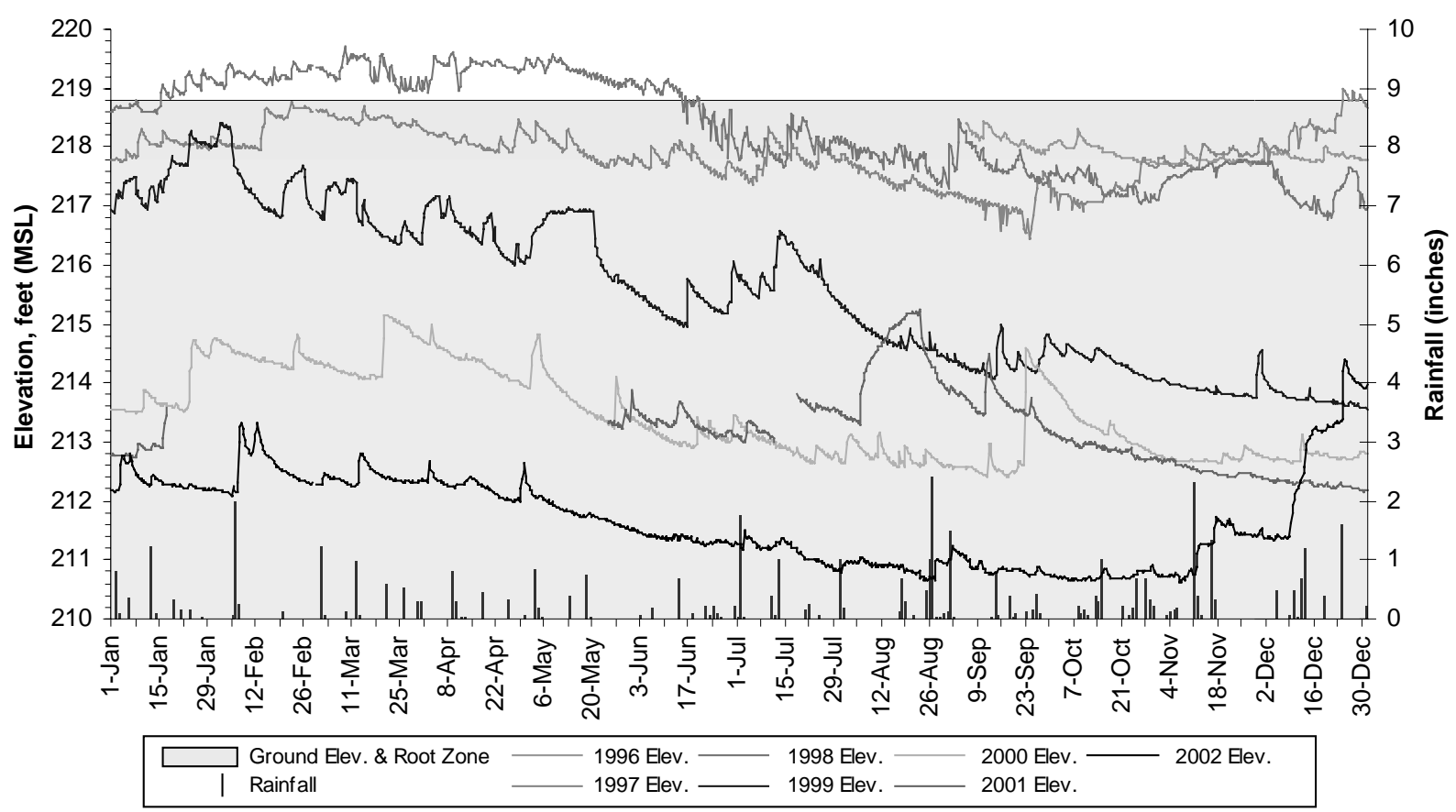

Figure 37 Comparison of hydraulic head elevation and rainfall at HPZ002A (H Area) in 2002

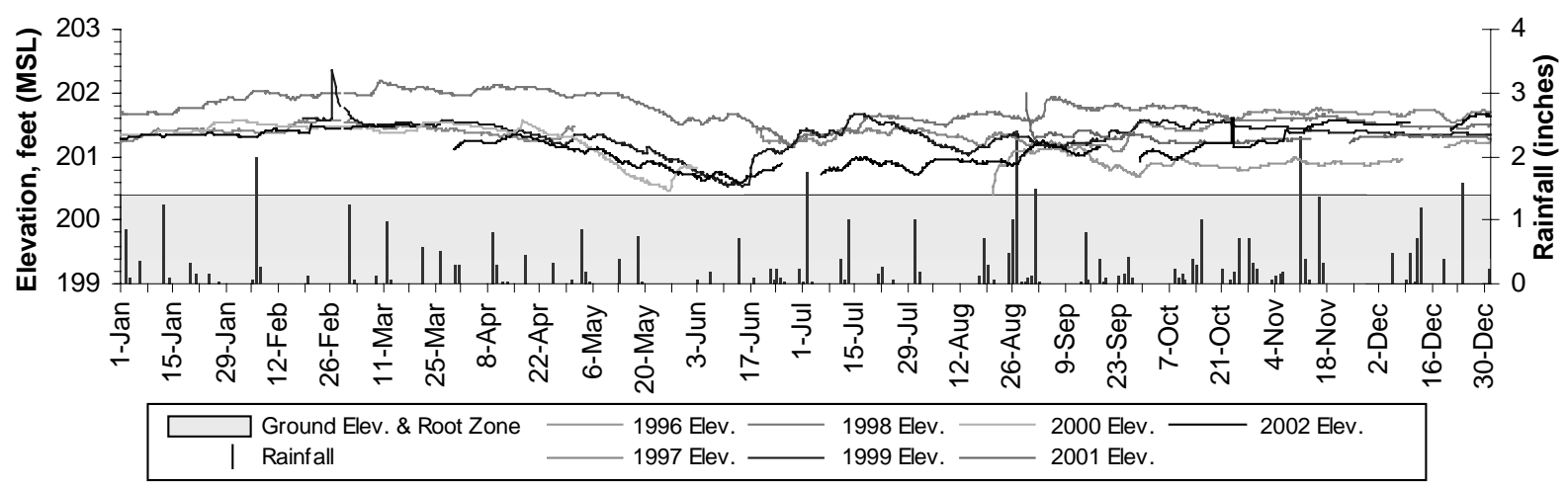

Figure 38 Comparison of hydraulic head elevation and rainfall at HPZ003A (H Area) in 2002 


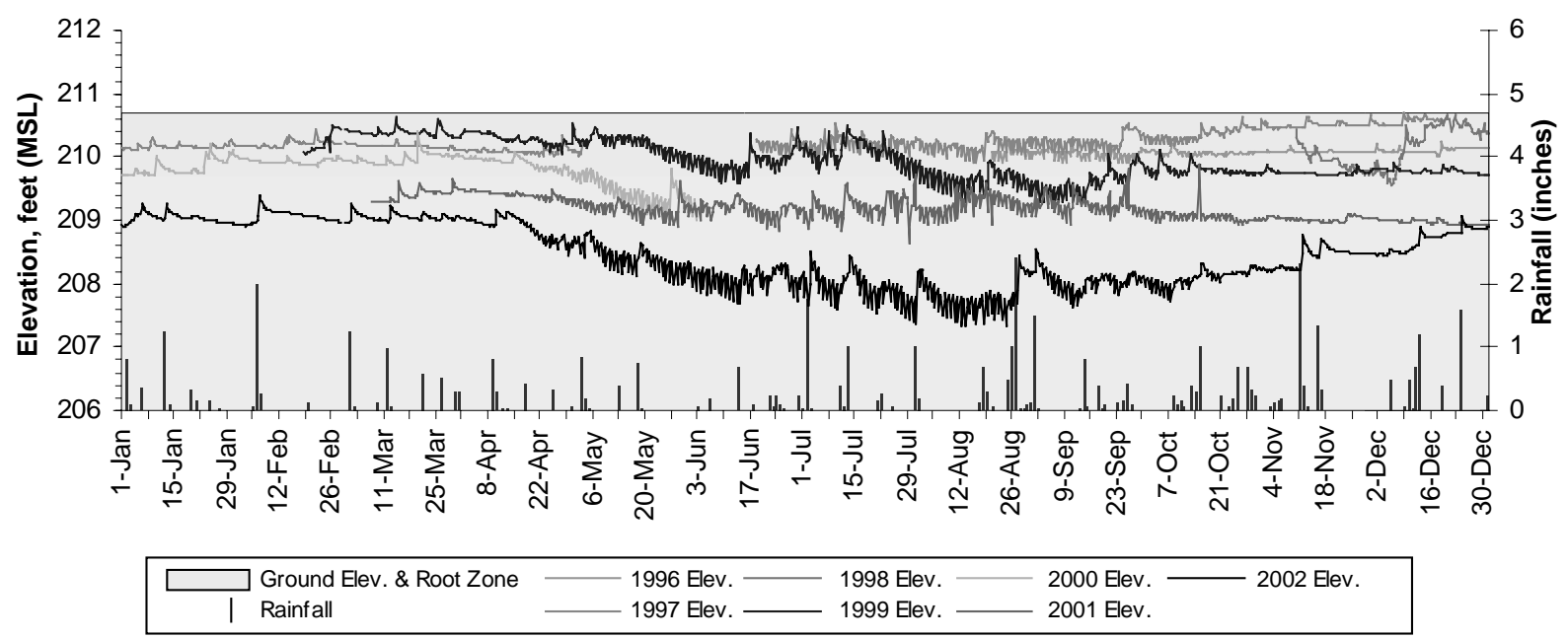

Figure 39 Comparison of hydraulic head elevation and rainfall at HPZ004A (H Area) in 2002

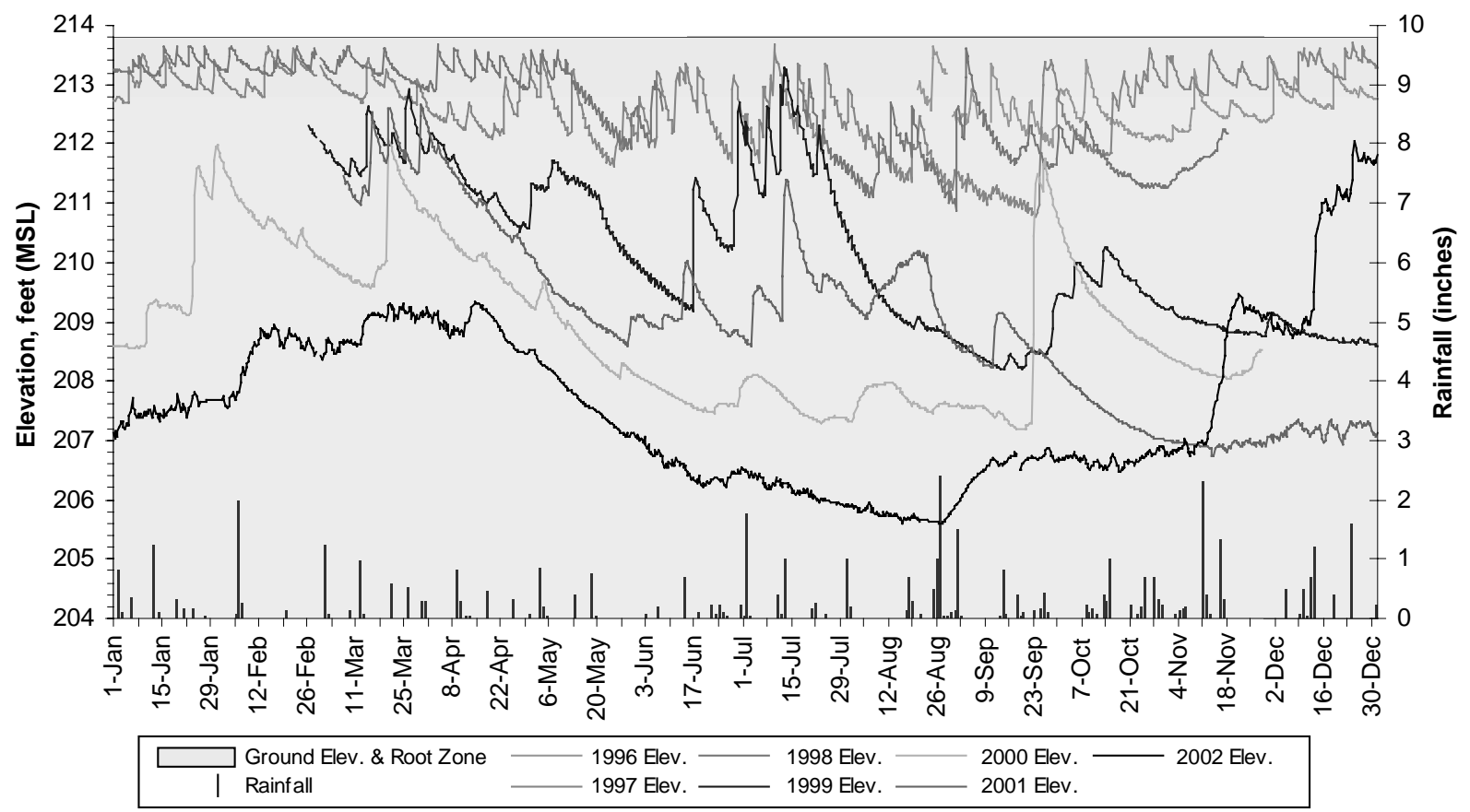

Figure 40 Comparison of hydraulic head elevation and rainfall at HPZ005A (H Area) in 2002 


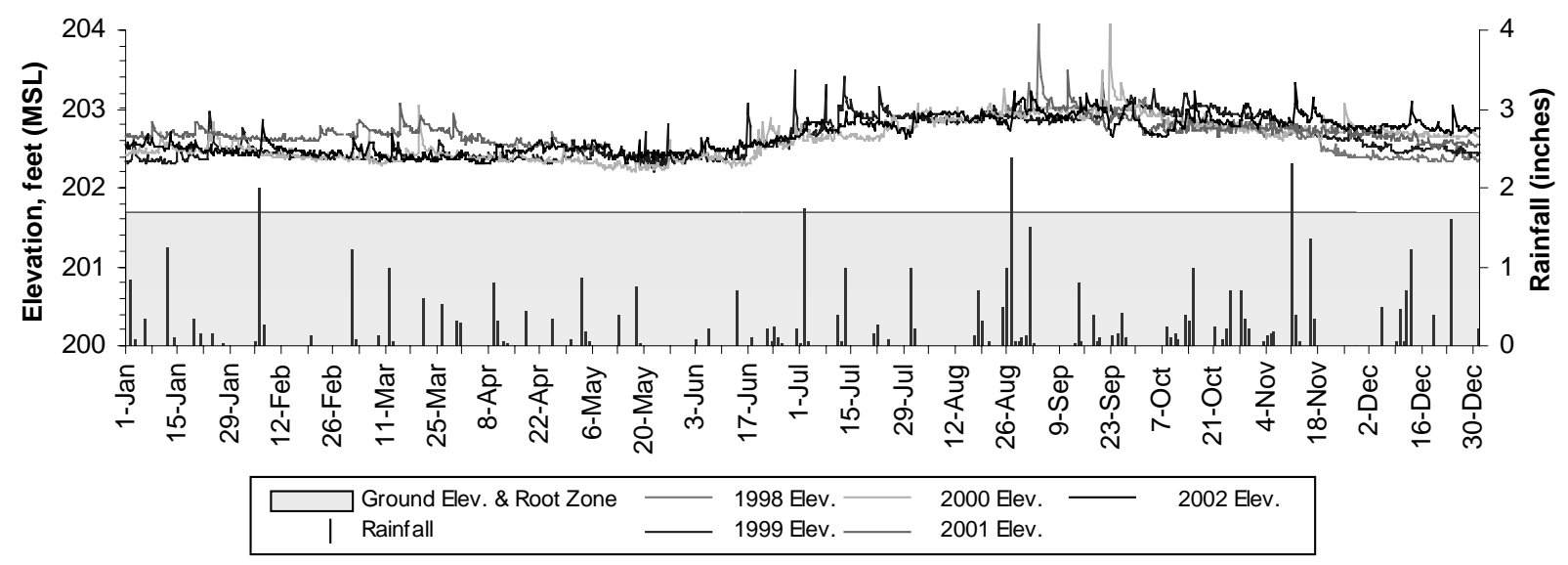

Figure 41 Comparison of hydraulic head elevation and rainfall at HPZ006A (H Area) in 2002

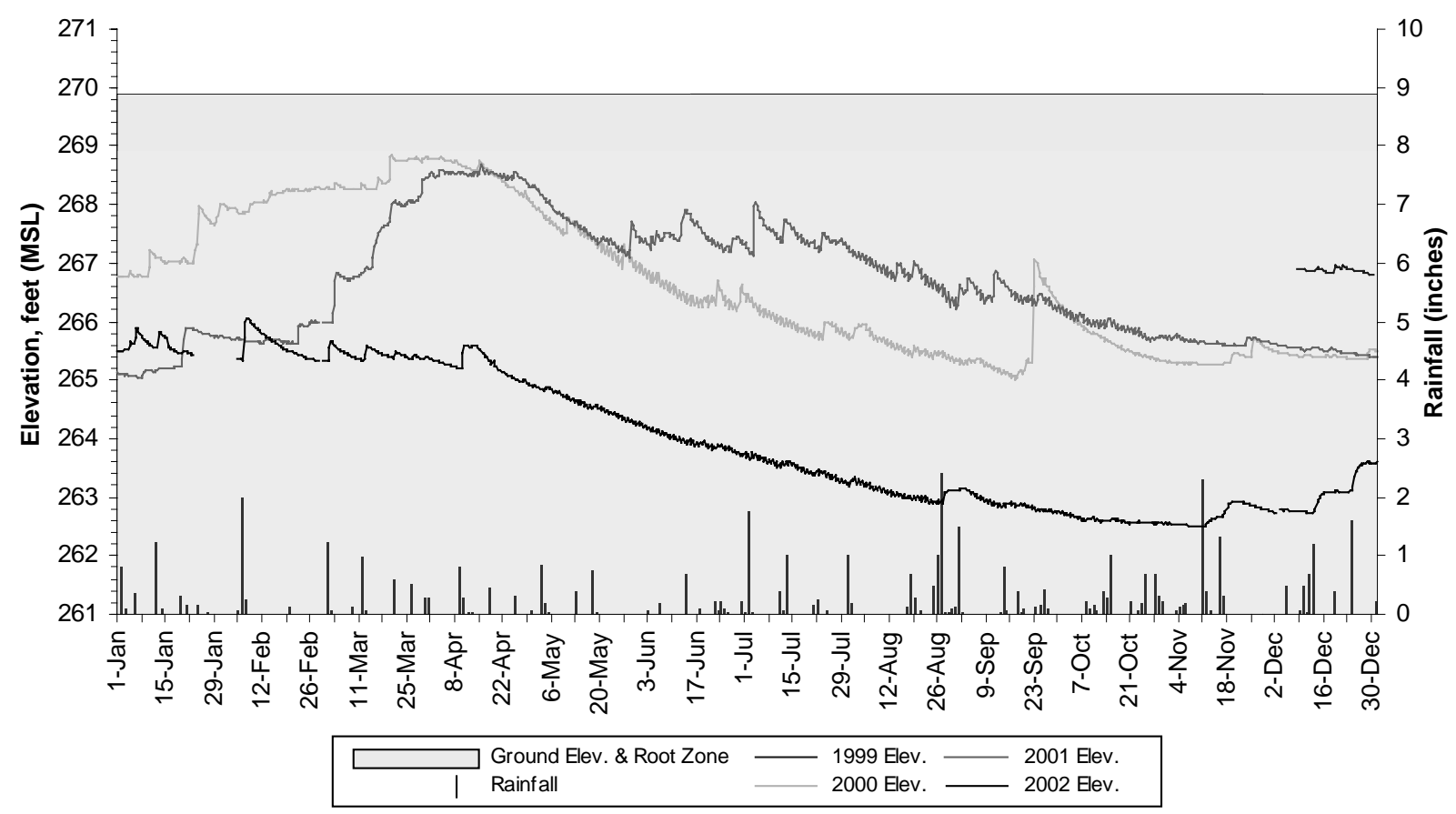

Figure 42 Comparison of hydraulic head elevation and rainfall (H Area) at FHR001 in 2002 


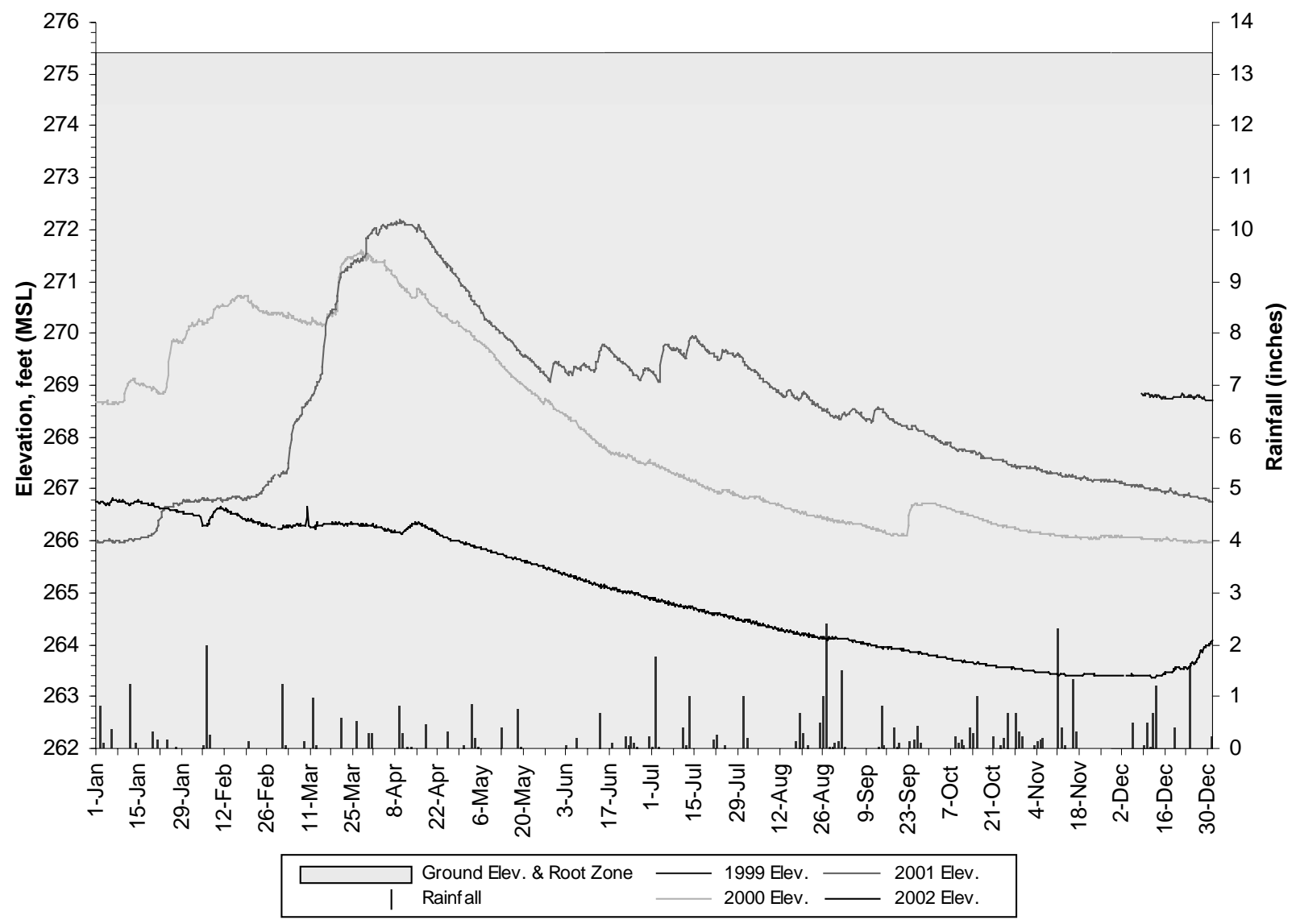

Figure 43 Comparison of hydraulic head elevation and rainfall (H Area) at FHR002 in 2002

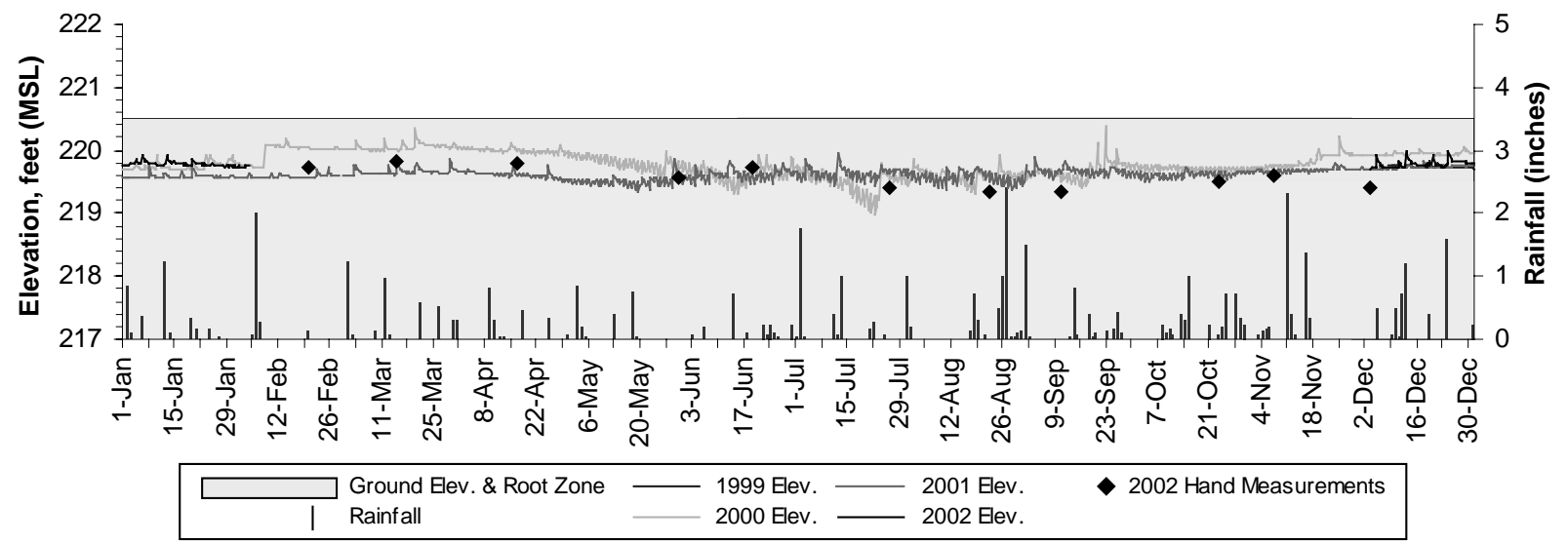

Figure 44 Comparison of hydraulic head elevation and rainfall (H Area) at FHR003 in 2002 


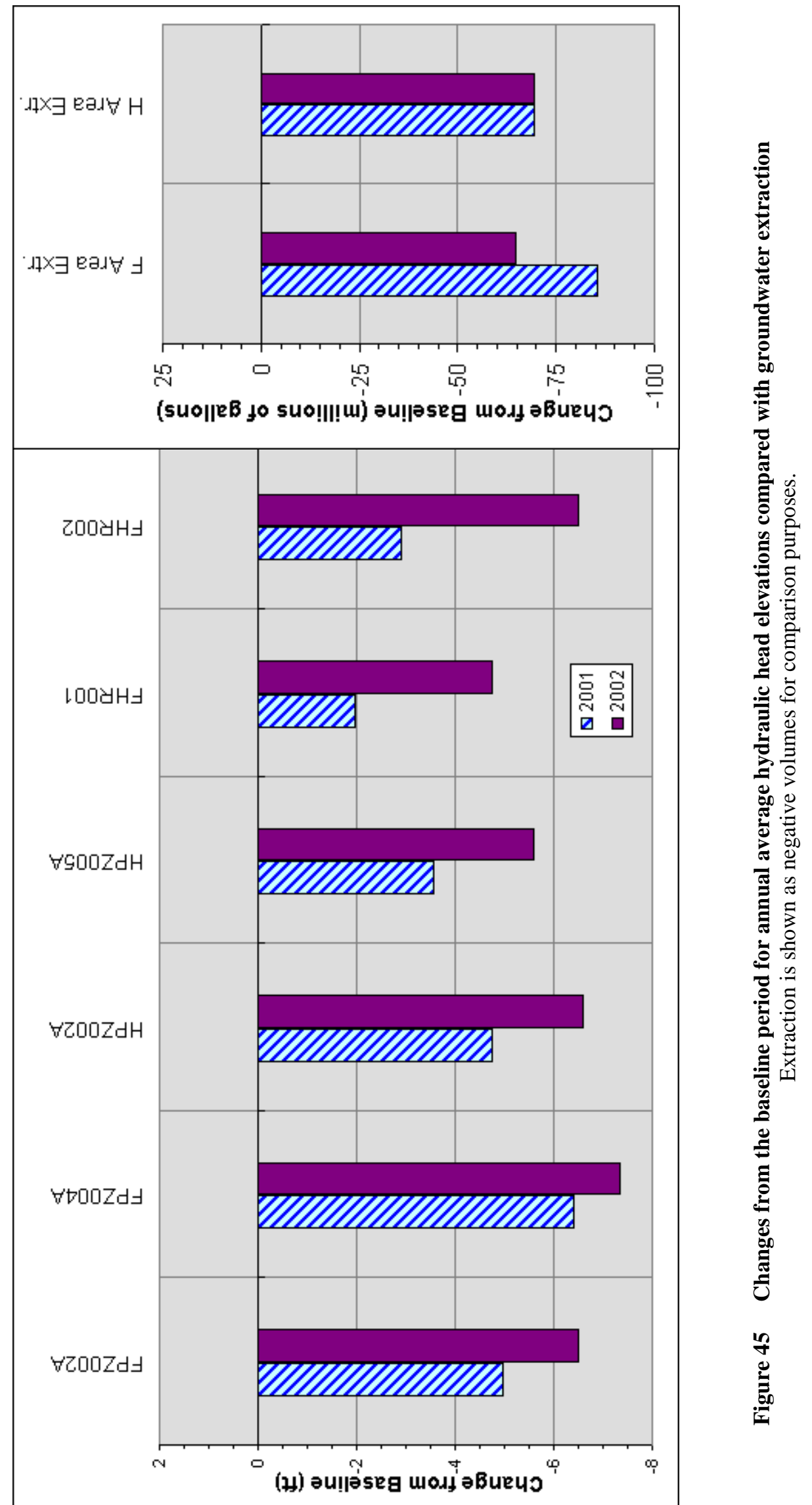




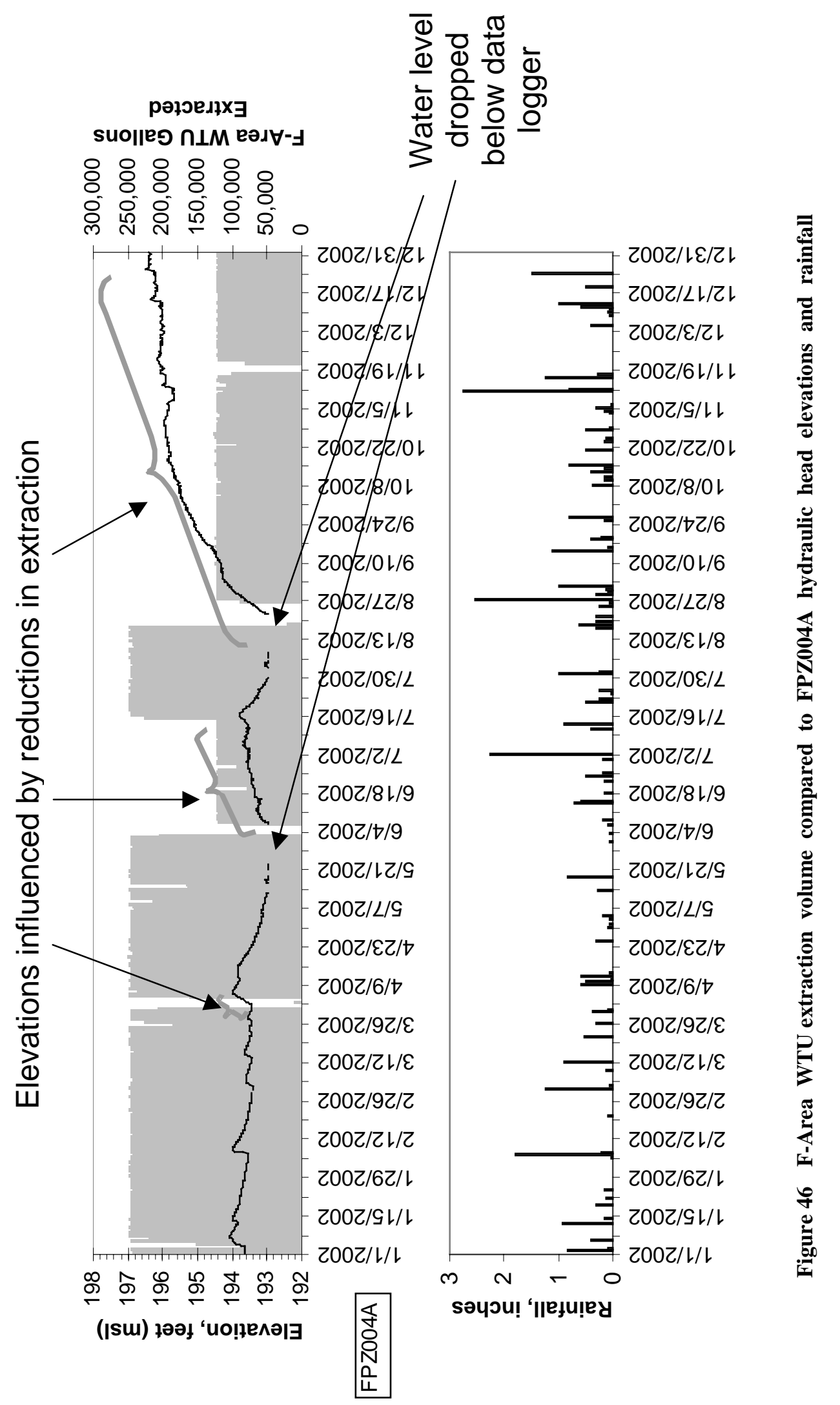




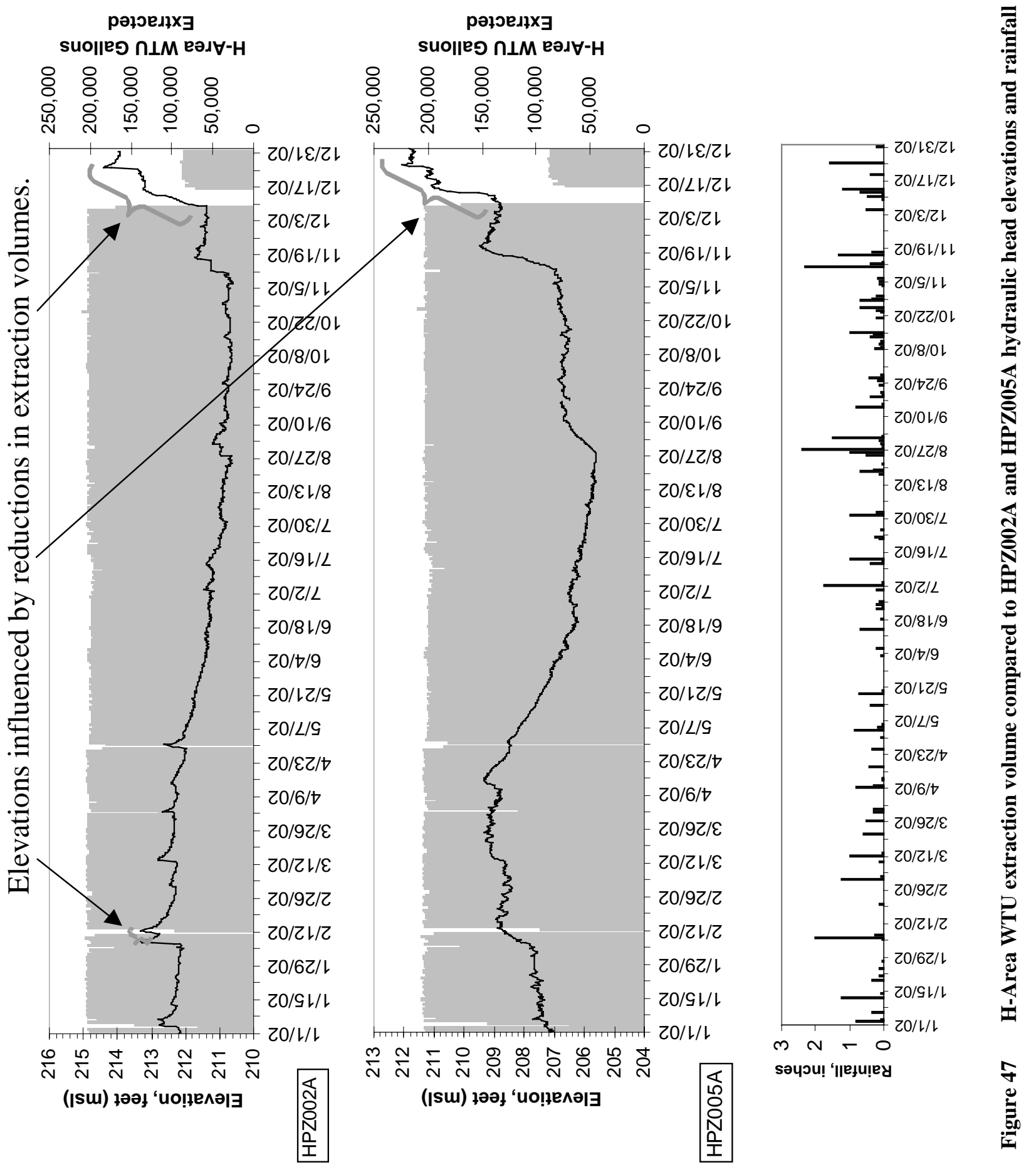

